
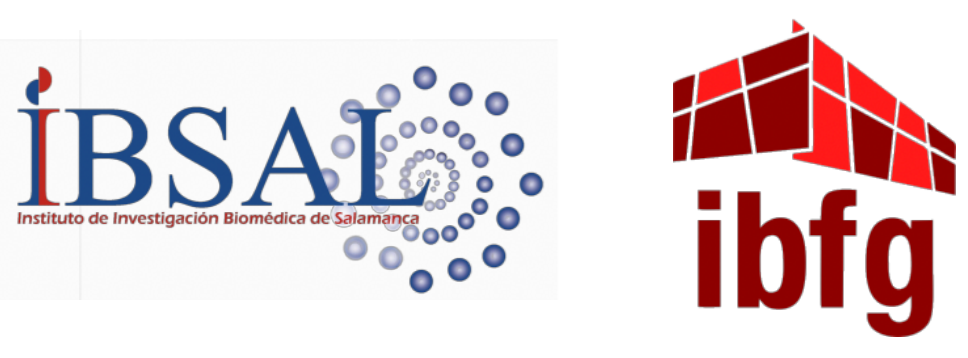

\title{
Función neuroprotectora de la terapia antioxidante drigida a la mitocondria en la isquemia cerebral
}

\section{TESIS DOCTORAL}

NORAH SAUD ALOTHMA

Salamanca, 2019 


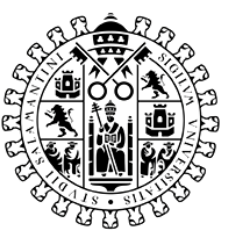

VNIVERSIDAD

BSALAMANCA

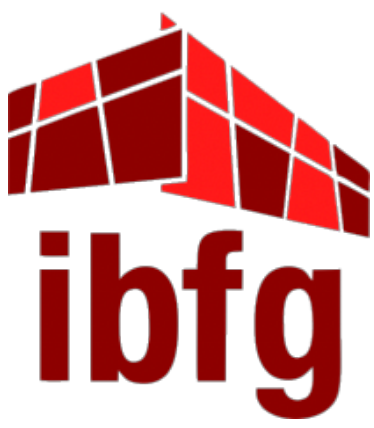

CAMPUS DE EXCELENCIA INTERNACIONAL

\title{
Función neuroprotectora de la terapia antioxidante drigida a la mitocondria en la isquemia cerebral
}

\author{
TESIS DOCTORAL \\ DRA. ÁNGELES ALMEIDA PARRA \\ DRA. CRISTINA RODRÍGUEZ GONZÁLEZ
}

Salamanca, 2019 
Dra. Ángeles Almeida Parra, Jefe del Grupo Neurobiología Molecular del Instituto de Investigación Biomédica de Salamanca (IBSAL. Hospital Universitario de Salamanca, Universidad de Salamanca, CSIC) y del Instituto de Biología Funcional y Genómica (IBFG. Universidad de Salamanca, CSIC) y Profesora Asociada del Departamento de Bioquímica y Biología Molecular de la Universidad de Salamanca y Dra. Cristina Rodríguez González, Investigadora del IBSAL y del IBFG

\section{CERTIFICAN:}

Que el trabajo doctoral realizado bajo su dirección por $\mathrm{D}^{\mathrm{a}}$ Norah Saud Alothman, titulado "Función neuroprotectora de la terapia antioxidante dirigida a la mitocondria en la isquemia cerebral", reúne las condiciones de originalidad requeridas para optar al grado de doctor por la Universidad de Salamanca y autorizan su presentación

Y para que así conste, firman la presente certificación en Salamanca, a 14 de junio de 2017.

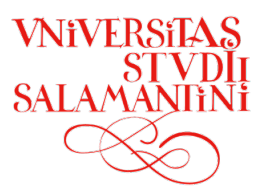

Fdo.: Ángeles Almeida Parra

Fdo.: Cristina Rodríguez González 


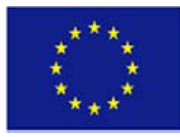

Este trabajo ha sido financiado con subvenciones concedidas por el Gobireno de Arabia Sudí (Ministerio de Educación, 1438-53512-2) y el Instituto de Salud Carlos III, a través del proyecto PI15/00473. 


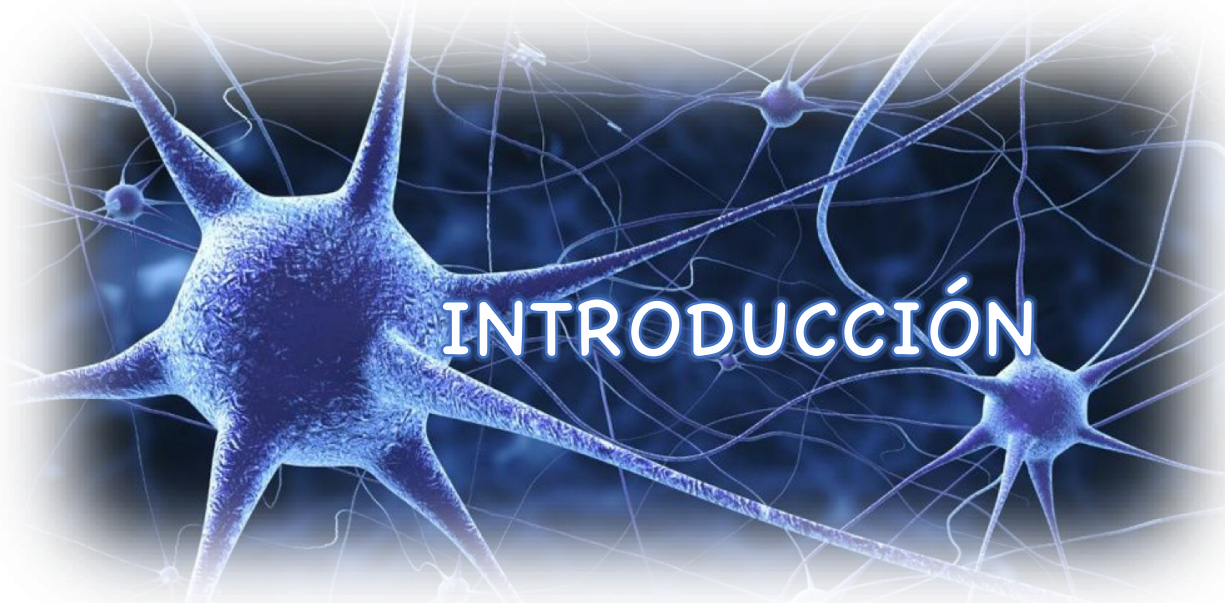




\section{ABREVIATURAS}

7-AAD: 7-amino-actinomicina D

ACM: Arteria cerebral media

AMPA: Ácido- $\alpha$-amino-3-(hidroxi-5-metil-4-isoxazolpropiónico)

ANOVA: Análisis de la Varianza

APC: Aloficocianina

ATP: Adenosina trifosfato

BB: Binding Buffer

BCA: Ácido bicincrónico

Bcl-2 /Bcl-xL: B-cell lymphoma 2

53BP1: p53 Binding Protein

BSA: Albúmina sérica bovina

CAT: Catalasa

CCCP: Carbonil cianuro 3- clorofenilhridrazona

Cdk1: Kinasa dependiente de ciclina 1

Cdk5: Kinasa 5 dependiente de ciclina

cDNA: DNA codificante

CMV: Citomegalovirus

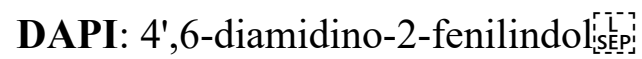

DilC1: 1,1', 3, 3, 3', 3' - hexametilindodicarbo - yoduro de cianina

DMSO: Dimetil Sulfóxido

DNA o ADN: Ácido Desoxirribonucleico

dNTPs: Desoxirribonucleótidos trifosfato

DTT: Ditiotreitol

EDTA: Ácido Etilendiaminotetraacético

FBS: Suero fetal de ternera

GABA: Acido gamma-aminobutírico

GAPDH: Gliceraldheído 3-fosfato deshidrogenasa

$\gamma$-GCS: $\gamma$-Glutamilcisteina sintetasa

GR : Glutation reductasa

GLU: Glutamato

GSH: Glutatión reducido

GSSG: Glutatión oxidado (disulfuro de glutatión)

HA: Hemaglutinina 
HANK's: Hank's Balanced Salt Solution

$\mathrm{H}_{2} \mathrm{O}_{2}$ : Peróxido de hidrógeno

ICAM-1: Molécula de adhesión intercelular 1

IL-1 $\beta$ : Interleuquinas

KA : Kainato

KRPG: Krebs Ringer Phosphate Glucose Buffer

LoxP: locus of X-over P1, sitio de reconocimiento Cre recombinasa

MAP2: Microtubule-Associated Protein 2

MAPK: Mitogen-activated protein kinase

Mcat / mCat: mitocatalasa (proteína/gen)

mGluR: Receptores metabotrópicos

NADPH: Dinucleótido de nicotinamida y adenina

NMDA: Ácido N-metil-D-aspartato

NMX:Nrmoxia

NO•: Óxido nítrico

NRF2 O NFE2L2: Nuclear factor erythroid-derived 2 - like 2

$\mathbf{O}_{2}{ }^{\bullet-:}$ : Anión superóxido

OGD: Oxigen and Glucose Deprivation

$\cdot \mathbf{O H}$ : radical hidroxilo

ONOO-: peroxinitrito

PBS: Tampón fosfato salino

PCR: Reacción en cadena de la polimerasa

RIPA: Radioimmunoprecipitation assay buffer

RNA o ARN: Ácido Ribonucleico

RNS: Especies Reactivas de Nitrógeno

ROS: Especies Reactivas de Oxígeno

S.E.M.: Error estándar de la media

SDS-PAGE: Electroforesis en gel de poliacrilamida con dodecil sulfato sódico

SNC: Sistema Nervioso Central

SOD1 o Cu/ZnSOD: Superóxido Dismutasa 1 o Cu/Zn-superóxido dismutasa

SOD2 o MnSOD: Superóxido Dismutasa 2 o Mn-superóxido dismutasa

SDS: Dodecil sulfato sódico

TGF- $\beta$ : Factor de crecimiento

TLR: Receptores toll-like 
TNF- $\alpha$ : Factor de necrosis tumoral

TRxR: Tiorredoxina Reductasa

TRxs: Tiorredoxinas

t-PA: Activador tisular del plasminógeno

TTBS: Tampón tris salino con tween 20

TEMED: N,N,N,N'-tetrametilendiamina

WT: wild type en referencia a genotipos silvestres

$\Delta \Psi \mathbf{m}$ : Potencial de membrana mitocondrial 


\section{ICTUS}

El ictus es una condición clínica que surge como consecuencia de una interrupción brusca del flujo de sangre al cerebro, lo que resulta en una disminución en el suministro de oxígeno y glucosa. Esto conduce a la muerte celular debido a la falta de nutrientes metabólicos necesarios para mantener la actividad cerebral [Caldeira et al. 2014, 50]. Es importante tener presente que el cerebro humano, aunque sólo supone el $2 \%$ del peso corporal, necesita casi un $20 \%$ de la tasa metabólica en reposo de un individuo para cubrir sus necesidades [Attwell and Laughlin 2001,1133; Bolaños, 2016, 115].

El ictus puede ocurrir bien por una obstrucción en los vasos sanguíneos, generalmente debido a una trombosis o placa de ateroma, o bien como resultado de la rotura de un vaso sanguíneo con la subsiguiente extravasación de la sangre [Nedergaard and Dirnagl 2005, 281]. Alrededor del 80-85\% de los accidentes cerebrovasculares son del primer tipo y se conocen como ictus isquémicos, mientras que el $15-20 \%$ son ictus hemorrágicos (Figura 1).

El ictus es uno de los problemas de salud pública más importantes en los países industrializados, siendo la segunda causa de muerte en todo el mundo según las estadísticas de la Organización Mundial de la Salud [Johnson et al. 2016, 634]. Según datos del Grupo de Estudio de Enfermedades Cerebrovasculares de la Sociedad Española de Neurología (GEECV-SEN), en España se detectan cada año 120.000 nuevos casos, produciéndose alrededor de unas 40.000 muertes anuales debido a esta enfermedad. Su importancia relativa varía según el género. Así, el ictus es la primera causa de mortalidad de mujeres y la segunda en varones. Por otro lado, la enfermedad cardiovascular es la principal causa de discapacidad en el adulto. En la mayoría de los casos, además, tiene lugar de forma repentina e inesperada, lo que produce un cambio significativo en la calidad de vida de los pacientes y su entorno. De hecho, el ictus es la segunda causa de demencia después de la enfermedad de Alzheimer, y la primera de discapacidad en mayores de 65 años [Masjuan et al. 2010, 384]. Todo ello conlleva un gasto social y sanitario importante, entre un 3 y un $6 \%$ del total.

Además del sexo y la edad, destacan otros factores de riesgo como la hipertensión, dislipemia, fibrilación auricular, diabetes mellitus, obesidad e infarto de miocardio, así como hábitos de vida poco saludables, como el tabaquismo y el sedentarismo [Gardener et al. 2015, 651; Boehme et al. 2017-472]. Las mejoras en la prevención y el tratamiento inicial han conseguido disminuir la tasa de mortalidad asociada con la enfermedad 
[Brouns et al. 2009, 483], pero el ictus sigue siendo un problema asistencial en continuo crecimiento [Feigin et al. 2015, 161]. Debido al envejecimiento de la población, se espera que el impacto social del accidente cerebrovascular aumente en las próximas décadas. Según los datos del Observatorio del Ictus (observatoriodelictus.com), uno de cada 6 españoles sufrirá un derrame cerebral a lo largo de su vida. Por lo tanto, el ictus es un importante problema social y de salud que requiere estrategias específicas para la detección, el manejo y el tratamiento.

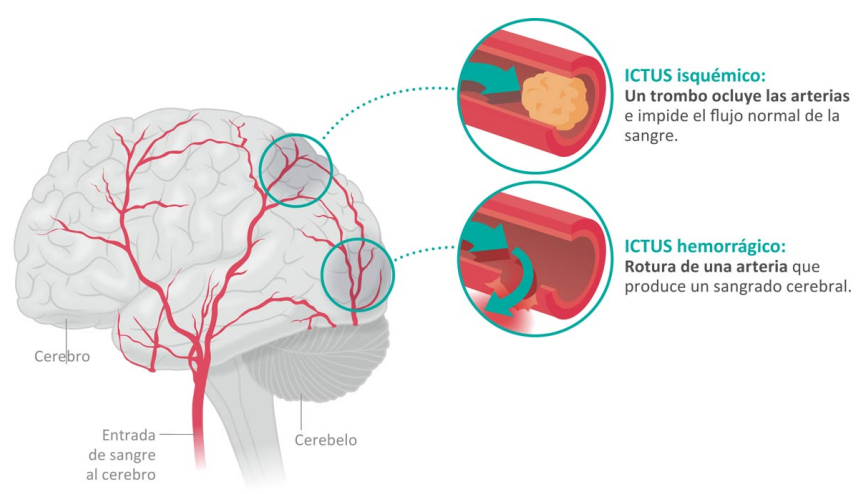

Figura 1. Clasificación de los tipos de ictus según su etiología. Ictus isquémico debido a una obstrucción vascular e ictus hemorrágico causado por la rotura de un vaso sanguíneo cerebral.

\subsection{Fisiopatología del ictus isquémico}

La isquemia cerebral tiene lugar de manera abrupta, si bien las alteraciones moleculares que se producen en las células nerviosas y vasculares de la zona afectada ocurren de manera secuencial a lo largo de un tiempo. Esta secuencia va a depender de la gravedad de la isquemia, de que sea permanente o transitoria y de que se apliquen o no medidas terapéuticas dirigidas a proteger el tejido afectado. El $80 \%$ de los ictus son de tipo isquémico, como ya se ha mencionado, causados por un bloqueo de la arteria que limita la irrigación sanguínea de un área del cerebro [Saenger and Christenson 2010, 21]. En estos casos, el flujo de sangre en gradiente determina dos regiones en el cerebro infartado. Una de ellas es la zona más afectada, denominada core o núcleo, que depende directamente de los vasos dañados y donde las células mueren por necrosis en unos pocos minutos debido a un fallo bioenergético total [Almeida et al. 2001, 15294; Moro et al. 2005, 1291; Bolaños et al. 2009, 1299; Brouns and De Deyn 2009, 483]. Alrededor del núcleo se define un área periférica de penumbra, menos vulnerable, que continuará recibiendo cantidades limitadas de nutrientes de los vasos sanguíneos circundantes y, por tanto, mantiene cierta actividad metabólica (Figura 2) [Caldera et 
al. 2014, 50]. La zona de penumbra es un concepto dinámico, ya que su superficie varía con el tiempo de acuerdo con el nivel de circulación arterial, la duración de la isquemia y el estado metabólico y funcional de las células [Bandera et al. 2006, 1334]. En esta región, las neuronas son funcionalmente inactivas, pero aún son viables si se restaura el flujo sanguíneo en las primeras 6 horas [Furlan et al. 1996, 216]. Los mecanismos moleculares de daño cerebral avanzan más lentamente, por lo que el tejido en la zona de penumbra es susceptible de recuperación si se normaliza el flujo sanguíneo y se interfiere en el progreso de la cascada isquémica [Castillo, 2002, 624; Donnan et al. 2008, 1612; Bolaños et al. 2009, 1299] Esto proporciona una ventana terapéutica y justifica la aplicación de medidas neuroprotectoras destinadas a prevenir la muerte celular y progresión de la lesión, al tiempo que se promueve la reparación de la función neurológica [Fernández-Gómez et al. 2008, 253; Ramos-Cabrer et al. 2011, S7; Liu 2012,331].

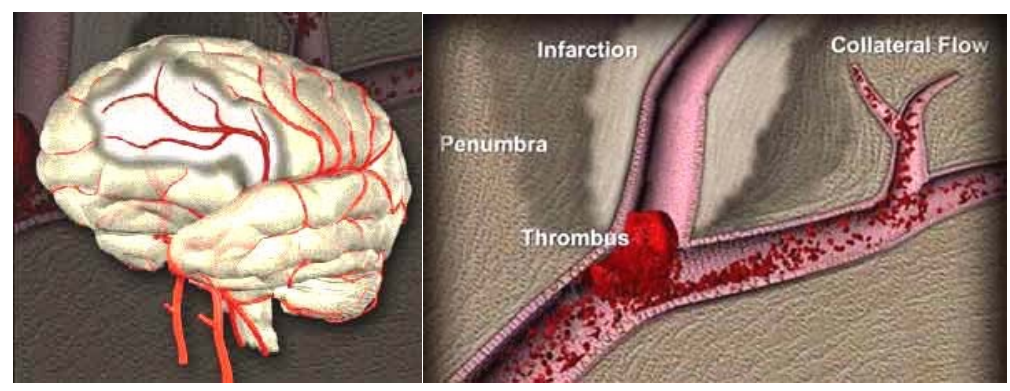

Figura 2. El núcleo y la penumbra en la isquemia cerebral. Tras la interrupción del flujo sanguíneo causada por un trombo se pueden distinguir dos áreas: el core o núcleo de la lesión (más claro) y la penumbra o región periférica (más oscura), a la que puede llegar la circulación lateral. (www.strokecenter.org)

\subsubsection{Bases moleculares de la isquemia cerebral. Cascada isquémica.}

Con la isquemia cerebral se desencadenan una serie de fenómenos moleculares que pueden llevar a la muerte celular. A estas reacciones químicas que tienen lugar en las células nerviosas se le conoce como cascada isquémica (Figura 3) [Castillo, 2002, 624; Bolaños, 2009, 1299; Almeida, 2013, 71]. La secuencia de eventos, que se superponen en el tiempo y el espacio, comienza en los primeros minutos después del inicio de los síntomas y continúa después de varios días. Inicialmente, se produce un fallo energético celular, debido a la falta de flujo cerebral, y se liberan moléculas que producen excitotoxicidad, incremento de $\mathrm{Ca}^{2+}$ intracelular y estrés oxidativo en el tejido 
isquémico. Al mismo tiempo se observa una disfunción de la barrera hematoencefálica, daño vascular, y se pone en marcha una respuesta inflamatoria que finalizará con la muerte celular, tanto de células neurales como endoteliales [Brouns and De Deyn 2009, 483; Gómez-Sánchez et al. 2011, 429; Rodríguez et al. 2017, 144].

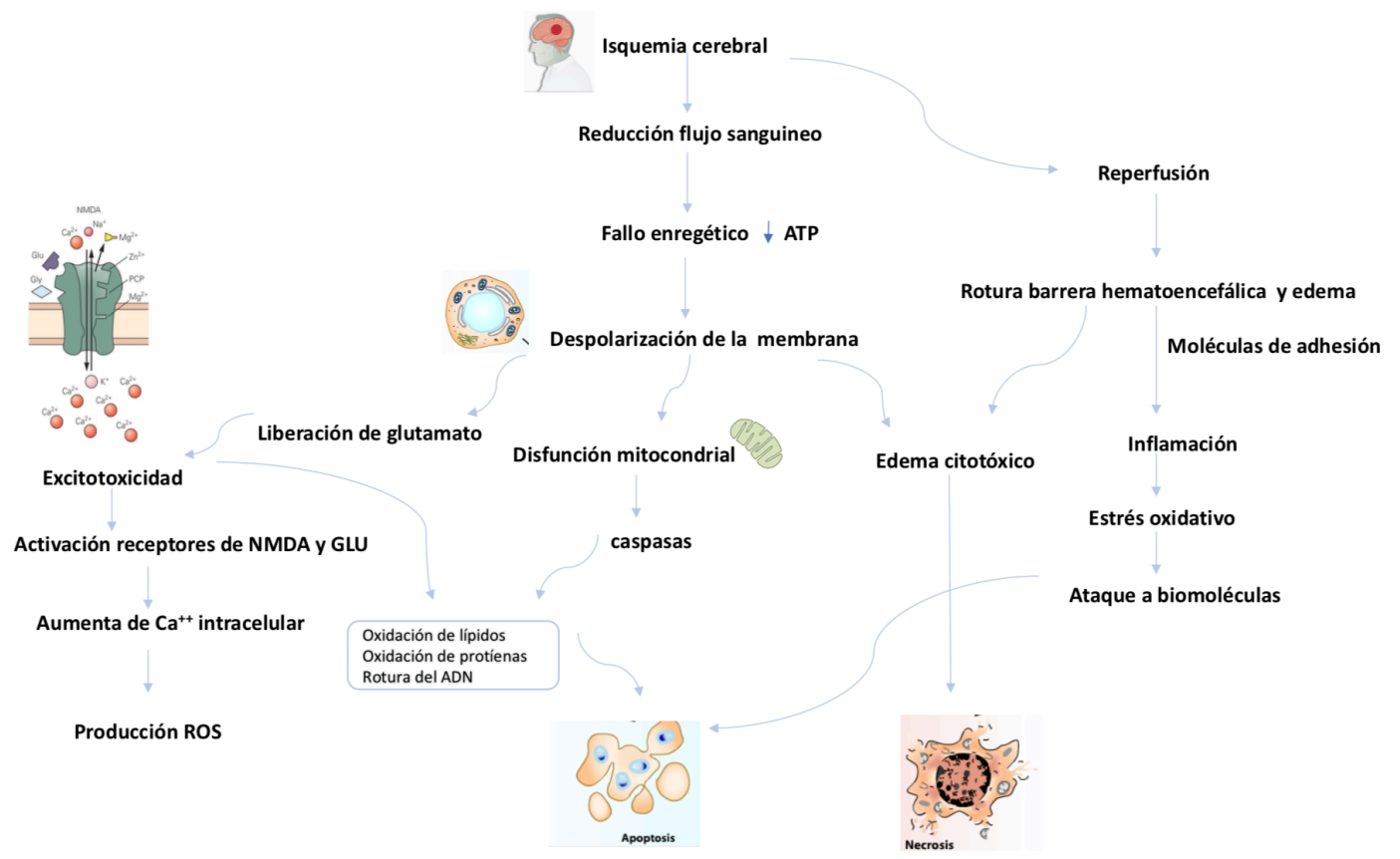

Figura 3. Esquema de la cascada isquémica. Se representan los principales eventos moleculares que tienen lugar como consecuencia de la isquemia.

\subsubsection{Fallo energético}

Una disminución repentina en la concentración de glucosa y la presión parcial de oxígeno en el área afectada por la isquemia conduce a la inhibición de la cadena de transferencia de electrones en las mitocondrias, bloqueando así la fosforilación oxidativa. La reducción del flujo sanguíneo reduce el aporte de estos recursos metabólicos y conduce al agotamiento de la energía en forma de ATP, lo que afecta el desempeño correcto de los procesos celulares dependientes de ATP [Katsura et al. 1994, 991]. Por un lado, se produce un mayor metabolismo anaeróbico de la glucosa, con la consiguiente acumulación de lactato en tejidos y la reducción del pH por debajo de los niveles fisiológicamente estables. Por otro lado, se altera el funcionamiento de las bombas de iones dependientes de ATP, perdiendo así el equilibrio iónico [Song et. 2014, 17]. Alteraciones en la bomba iónica $\mathrm{Na}^{+} / \mathrm{K}^{+}$de la membrana celular provocan la despolarización de la membrana con liberación de $\mathrm{K}^{+}$al espacio extracelular y entrada de $\mathrm{Na}^{+}$al interior de la célula. El fallo energético también afecta a las bombas iónicas que mantienen baja la concentración intracelular de $\mathrm{Ca}^{2+}$, provocando un 
aumento en la concentración intracelular del mismo [Broughton et al. 2009, e331].

\subsubsection{Excitotoxicidad}

El glutamato es el principal neurotransmisor excitador del Sistema Nervioso Central. Para el desarrollo de sus funciones el glutamato interacciona con diferentes tipos de receptores, que se clasifican en ionotrópicos y metabotrópicos en función de sus características bioquímicas, farmacológicas y electrofisiológicas [Michaelis, 1998, 369].

Los receptores ionotrópicos (canales catiónicos operados por ligandos) son los receptores de $N$-metil-D-aspartato (NMDA), ácido alfa-amino-3-hidroxi-5-metil-4isoxazolepropiónico (AMPA) y kainato (KA). Los NMDA, son permeables a $\mathrm{Na}^{+}$y $\mathrm{Ca}^{2+}$, mientras que los AMPA y KA son principalmente permeables a $\mathrm{Na}^{+}$[Monaghan et al. 1989, 365].

Los receptores metabotrópicos (acoplados a proteínas G) se clasifican en Grupo I (mGluR 1 y 5), Grupo II (mGluR 2 y 3) y Grupo III (mGluR 4, 6, 7 y 8) [Kew and Kemp 2005, 320]

Los niveles de glutamato han de ser reestablecidos después de la transmisión del impulso nervioso. De no ser así, la acumulación excesiva de glutamato en el espacio extracelular causa una sobreactivación de los receptores de glutamato en las neuronas vecinas provocando incluso su muerte. Este fenómeno se conoce como excitotoxicidad [Olney et al. 1971, 294; Rothman et al. 1986, 105; Choi et al. 1988, 623] y tiene lugar después de la isquemia, momento en que las células nerviosas se encuentran en un estado de hiperexcitabilidad y liberan gran cantidad de glutamato al espacio extracelular [Lai et al 2014, 157].

La despolarización de membrana y la acumulación de $\mathrm{Na}^{+}$intracelular en la isquemia llevan a un fallo de los transportadores de glutamato $\mathrm{Na}^{+}$-dependientes que, en condiciones fisiológicas, consiguen mantener baja la concentración sináptica de glutamato. El incremento del glutamato sináptico estimula los receptores ionotrópicos de NMDA, que son los principales responsables del daño neuronal que sigue a la isquemia [Almeida et al. 1995, 480; Delgado-Esteban et al. 2000, 1618; Almeida and Bolaños 2001, 676; Arundine and Tymiansky, 2003, 325]. Al ser permeables a Ca ${ }^{2+}$ fomentan su acumulación en el citosol en las neuronas [Sattler et al. 2000, 529; Orrenius et al. 2003, 552], lo que contribuye en gran medida al desequilibrio iónico [Rodriguez- 
Rodriguez et al. 2013, 750]. A la vez, los receptores AMPA, aunque en condiciones fisiológicas son menos permeables al $\mathrm{Ca}^{2+}$, incrementan su permeabilidad hasta 18 veces en situación de isquemia [Olney 1969, 719]. La estimulación de los receptores metabotrópicos también puede contribuir a la excitotoxicidad. Por ejemplo, la estimulación de mGluR1 (que se expresa en neuronas GABAérgicas) inhibe la liberación del neurotransmisor inhibidor ácido gamma-aminobutírico (GABA) y mGluR5, conectado física y funcionalmente con los receptores NMDA, amplifica la activación de éstos [Pellegrini-Giampietro 2003, 461].

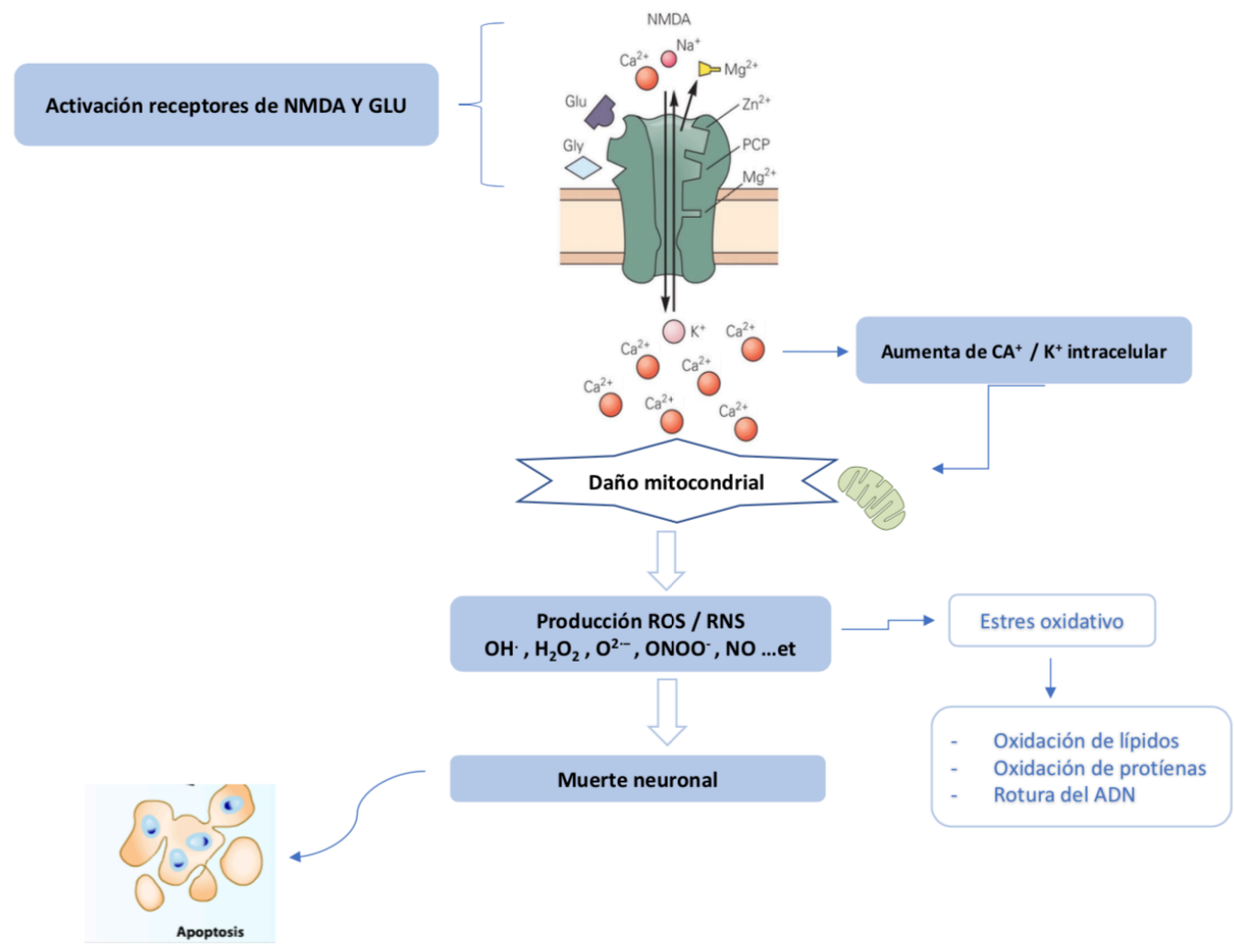

Figura 4. Representación esquemática de los eventos que tienen lugar después del estímulo excitotóxico.

Entre los eventos que tienen lugar en la célula a consecuencia del estímulo excitotóxico, destacan el incremento en la producción de radicales libres tras la activación de enzimas como la óxido nítrico sintasa [Bolaños et al. 1997, 2227; Bolaños and Almeida 1999, 415; Almeida and Bolaños 2001, 676; Parathath et al. 2007, 1938], la activación de proteínas que regulan la señalización transcripcional de genes de muerte celular, como la familia de las quinasas MAPK [Raingeaud et al. 1995, 7420] y la activación de proteasas como las calpaínas [Araújo et al. 2010, 1966]. La activación de Cdk5 por calpaínas tras un estímulo excitotóxico conduce a la muerte neuronal por apoptosis 
mediada por una activación aberrante de proteínas de ciclo celular [Maestre et al. 2008, 2736; Veas-Pérez de Tudela et al. 2016, 18180]. Además, la acumulación de quinasas dependientes de ciclinas, en concreto Cdk1, modifica la estructura de la ATP-sintasa de la cadena trasportadora de electrones inhibiendo la fosforilación oxidativa [VeasPérez De Tudela et al. 2015, 9287].

En definitiva, la excitación fisiológica de los receptores NMDA es imprescindible para la supervivencia neuronal [Jimenez-Blasco et al. 2015, 1877]. Sin embargo, una activación exacerbada como la que tiene lugar después de la isquemia, activa cascadas de señalización dependiente de $\mathrm{Ca}^{2+}$ que conllevan a la disfunción mitocondrial y la muerte neuronal [Banasiak y col., 2000, 215; Green and Kroemer, 2004, 626].

\subsubsection{Aumento del $\mathrm{Ca}^{2+}$ intracelular}

El aumento de $\mathrm{Ca}^{2+}$ intracelular en las neuronas se produce a través de receptores NMDA, AMPA, canales de $\mathrm{Ca}^{2+}$ dependientes de voltaje o por liberación intracelular desde la mitocondria o el retículo endoplasmático. $\mathrm{El} \mathrm{Ca}^{2+}$ es un importante mensajero secundario en estas células, de modo que su acumulación fomenta la activación de un gran número de enzimas causando un desequilibrio metabólico. Así, la proteína quinasa $\mathrm{C}$, las fosfolipasas $\mathrm{A}_{2}$ y $\mathrm{C}$, la ciclooxigenasa, la óxido nítrico sintasa, la calpaína y otras proteasas y endonucleasas se activan en condiciones patológicas. Como consecuencia se producen especies reactivas de oxígeno y se liberan moléculas proinflamatorias y productos de degradación, que a su vez activarán genes que participan en inflamación, apoptosis y/o necrosis [Yuan et al. 2003, 401; Mehta et al., 2007, 34, Eltzschig et al., 2011, 1391].

\subsubsection{Especies reactivas de oxígeno y estrés oxidativo}

El estrés oxidativo es causado por un desequilibrio entre la producción de especies reactivas de oxígeno (ROS) y nitrógeno (RNS) y la capacidad antioxidante de un sistema biológico [Rodrigo et al. 2013, 698; Bolaños 2016, 115]. En la isquemia, y principalmente durante la reperfusión, distintos mecanismos pueden generar un exceso de ROS y RNS, como es el aumento de $\mathrm{Ca}^{2+}$, la disfunción mitocondrial o los procesos inflamatorios, que detallaremos más adelante. Moléculas como el anión superóxido $\left(\mathrm{O}_{2}{ }^{\bullet}\right)$, el peróxido de hidrógeno $\left(\mathrm{H}_{2} \mathrm{O}_{2}\right)$, el radical hidroxilo $\left({ }^{\circ} \mathrm{OH}\right)$, el óxido nítrico $(\mathrm{NO})$ y el peroxinitrito $\left(\mathrm{ONOO}^{-}\right)$pueden contribuir al estrés oxidativo y provocar daños 
en proteínas y lípidos [Bolaños et al. 1994, 910; Bolaños et al. 1995, 1965; Moro et al. 2005, 1291; Bolaños et al. 2009, 1299]. Adicionalmente, pueden ocasionar fragmentación del DNA [Temple et al. 2005, 319; Poyton et al. 2009, 332; Hekimi et al. 2011, 569; Halliwell 2011, 125]

En condiciones normales, los ROS participan como segundos mensajeros en distintas rutas de señalización, de modo que los niveles controlados de ROS son esenciales para mantener procesos fisiológicos en la célula [Holmström and Finkel 2014, 411]. En el sistema nervioso central cabe destacar su papel antioxidante [Bolaños 2016, 115]. Además, se ha visto que los ROS son importantes para la proliferación celular [Diebold and Chandel 2016, 86] y diferenciación neuronal, así como para el mantenimiento de la sinapsis [Oswald, 2018, 679]. Recientemente se ha confirmado también que los ROS mitocondriales de astrocitos regulan el metabolismo cerebral y el comportamiento [Vicente-Gutierrez et al. 2019, 201]. Sin embargo, el exceso de ROS está directamente relacionado con el daño isquémico en neuronas [Almeida et al. 2002, 207]. Por un lado, los ROS se acumulan como un subproducto de la cadena respiratoria durante el período de oclusión, así como durante el proceso de reoxigenación [Moro et al. 2005, 1291; Bolaños et al. 2009, 1299]. También se generan por la activación patológica de enzimas, como la xantina oxidasa y la ciclooxigenasa [Rodrigo et al. 2013, 698] o durante la respuesta inflamatoria, como sucede con las óxido nítrico sintasas [Moro et al. 2004, 265] o las NADPH oxidasas [Gray and Jandeleit-Dahm 2015, 5933].

Las NADPH oxidasas (NOX, del inglés Nicotinamide adenine dinucleotide phosphate OXidases) forman complejos enzimáticos asociados a la membrana plasmática. La mayoría de isoformas catalizan la reducción de $\mathrm{O}_{2}$ en anión superóxido $\left(\mathrm{O}_{2}{ }^{*}\right)$ utilizando NADPH como donador de electrones [Bedard and Krause 2007, 245]. Cabe mencionar que NOX4 produce principalmente $\mathrm{H}_{2} \mathrm{O}_{2}$ y se localiza en la membrana mitocondrial y endoplasmática [Petry et al. 2006, 1473]. Pese a la importancia de estas enzimas y a la existencia de muchas otras en diferentes orgánulos celulares, como es el caso de la mencionada xantina oxidasa peroxisomal que participa en la formación de $\mathrm{O}_{2}{ }^{\bullet}$ y $\mathrm{H}_{2} \mathrm{O}_{2}$ en la $\beta$-oxidación, la mitocondria destaca por ser la principal fuente de ROS celulares. Esto sucede como consecuencia de la actividad de la cadena de transporte de electrones [Murphy 2009, 1]. A través de estos procesos mitocondriales se estima que un 1-3\% de oxígeno puede reducirse de manera incompleta generándose anión superóxido en lugar 
de reducirse completamente a $\mathrm{H}_{2} \mathrm{O}$ [Green et al 2011, 1109; Murphy 2009, 1; Bolaños et al. 2009]. En concreto, los complejos I y III producen $\mathrm{O}_{2}{ }^{*-}$ que es rápidamente transformado en $\mathrm{H}_{2} \mathrm{O}_{2}$ por las superóxido dismutasas (SOD2 o MnSOD) localizadas en la mitocondria [Brand 2010, 7]. Por otro lado, el anión superóxido $\left(\mathrm{O}_{2}{ }^{\bullet-}\right)$ puede reaccionar en presencia de hierro dando lugar a radicales hidroxilo $\left({ }^{\circ} \mathrm{OH}\right)$ mediante la reacción de Fenton [Kowaltowski et al. 2009, 333].

Debido a su alta reactividad, los ROS interaccionan con proteínas, fosfolípidos de membrana y DNA, causando peroxidación lipídica, daño en membranas, disfunción mitocondrial y mutaciones en el DNA, tanto nuclear como mitocondrial [Barzilai and Yamamoto 2004, 1109; Niki 2009, 469; Yan 2014, 343154]. Entre los efectos destacan la pérdida de bases, la formación de 8-oxo-guanina o las roturas de cadena simple y cadena doble de DNA. De modo que el estrés oxidativo puede dar lugar a mutaciones o cambios epigenéticos que generan inestabilidad cromosómica [Nathan and Cunningham-Bussel 2013, 349]. Todo ello, además, conduce a la pérdida de la homeostasis y la desregulación de los procesos celulares, no sólo en neuronas y glía, sino también en células endoteliales y células del sistema inmunológico [Basuroy et al. 2008, C422; Brouns et al. 2009, 483].

En el sistema nervioso central la producción de ROS varía entre los diferentes tipos celulares. Se ha visto que astrocitos y neuronas presentan diferencias en la organización de los complejos de la cadena respiratoria y, por tanto, en la producción de ROS mitocondriales (mROS). Así, el ensamblaje del complejo I en supercomplejos parece ser la causa de la menor producción de ROS en neuronas [López-Fabuel et al. 2016, 13063]. Este hecho explicaría, a su vez, las diferencias bioenergéticas entre ambos y la dependencia de las neuronas de la fosforilación oxidativa para la neurotransmisión y supervivencia [Almeida et al. 2001, 15294; Almeida et al. 2004, 45; Herrero-Méndez et al. 2009, 747; Veas-perez de Tudela, 2015, 9287]. Sin embargo, no sólo la cantidad de ROS parece ser importante para determinar su efecto nocivo, sino que cada vez cobra más importancia el lugar donde se producen estas especies reactivas. En condiciones patológicas como la isquemia, el transporte reverso de electrones (RET, del inglés Reverse Electron Transport) en el complejo I es la principal fuente de ROS durante la reperfusión de los tejidos [Chouchani, 2016, 254]. Se ha visto que los tejidos isquémicos acumulan succinato [Chouchani et al. 2014, 431]. Durante la reperfusión, 
el succinato es rápidamente oxidado por el complejo II produciendo RET-ROS, que causan daño oxidativo y muerte celular. De nuevo, el uso de antioxidantes que específicamente neutralicen los ROS producidos o minimicen su producción en la mitocondria podrían aliviar los efectos de la isquemia-reperfusión y/o proteger frente al daño asociado al ictus [Brand 2016, 14; Scialó et al. 2017, 428].

La participación del estrés oxidativo en el daño neuronal isquémico queda patente también en los efectos del Nrf2 (Nuclear factor erythroid-related factor 2). Se trata de un factor de transcripción que regula un conjunto de genes antioxidantes que actúan de forma sinérgica para eliminar el exceso de ROS [Nguyen et al. 2009, 13291; JimenezBlasco et al. 2015, 1877]. Distintos estudios experimentales han demostrado que el incremento de la actividad Nrf2 reduce el daño isquémico en el cerebro [Shih et al. 2005, 10321: Johnson et al. 2008, 61].

\subsubsection{Inflamación}

Los procesos inflamatorios tienen un papel muy importante en el ictus isquémico. En la fase aguda, la inflamación contribuye al daño cerebral. Sin embargo, los datos experimentales sugieren que la cascada de acontecimientos que acompañan a la respuesta inmune es compleja y puede tener tanto efectos perjudiciales como beneficiosos en el pronóstico [Doyle et al. 2008, 310; Iadecola and Anrather 2011, 796; Jin et al. 2013, 834].

La respuesta inflamatoria se caracteriza por la respuesta celular y la liberación de citoquinas y otros mediadores en el cerebro isquémico [Siniscalchi 2014, 131]. Así, el ictus se acompaña de neutrofilia, linfocitopenia y activación de microglia y macrófagos [Ross et al. 2007, 203; Anrather and Iadecola 2016, 661]. La acumulación de neutrófilos se observa rápidamente en el tejido isquémico. Este fenómeno está favorecido por la disrupción de la barrera hematoencefálica y causa daño tisular por la liberación de radicales libres proinflamatorios y enzimas proteolíticos [Huang et al. 2006, 232]. Además, previene la restauración de flujo sanguíneo después de la reperfusión, lo que empeora el pronóstico. Los linfocitos, que en condiciones normales están ausentes en el cerebro, también median la respuesta inflamatoria después de un ictus isquémico [Liesz et al. 2015, 1422]. Una respuesta más tardía incluye la movilización de células derivadas de la médula ósea. Esto da lugar a respuestas antiinflamatorias, que incluye la eliminación de restos celulares mediante fagocitosis y 
la liberación de citoquinas [Huang et al. 2006, 232]. Las citoquinas más estudiadas son TNF- $\alpha$ (factor de necrosis tumoral con carácter proinflamatorio), las interleuquinas IL$1 \beta$ (también proinflamatoria), IL-6, IL-10 y el factor de crecimiento TGF- $\beta$, con efecto neuroprotector [Zhu et al. 2002, 3898]. El papel de la inmunidad innata, en concreto de los receptores toll-like (TLR), es importante para evitar la invasión de patógenos. Sin embargo, se ha visto que la expresión de TLR2 y TLR4 está asociada con peor pronóstico y mayor respuesta inflamatoria en ictus isquémico [Urra et al. 2009, 1262; Brea et al. 2011, 1424]. De hecho, recientemente se ha publicado una estrategia que emplea aptámeros de DNA para bloquear el receptor TLR4 y que se asocia con un efecto protector después de la isquemia en modelos animales [Fernández et al. 2018, 2047].

Otras moléculas de adhesión celular son necesarias para la invasión de los leucocitos tras el ictus, como es el caso de las selectinas (E y P principalmente) y la molécula de adhesión intercelular 1 (ICAM-1) [Anrather and Iadecola 2016, 661]. También son relevantes las metaloproteinasas de matriz (MMP2 y 9 principalmente), enzimas proteolíticas responsables del remodelamiento de la matriz extracelular que se activan en el cerebro en respuesta al daño isquémico [Montaner et al. 2001, 1759; Castillo et al. 2009, 256].

\subsubsection{Muerte celular}

Minutos después de un ictus isquémico el tejido cerebral privado de flujo sanguíneo muere rápidamente por necrosis. Es un tipo de muerte independiente de caspasas que está asociado a fallos en la membrana plasmática y a edema citotóxico [Peter 2011, 310]. El aumento excesivo de $\mathrm{Ca}^{2+}$ intracelular activa el sistema calpaína-catepsina que inicia una cascada de señalización que culmina con la dilatación de orgánulos celulares y de la membrana plasmática hasta que su integridad se ve comprometida. En ese momento se produce la liberación de material intracelular al medio, aumentando la excitotoxicidad, la inflamación y por tanto el daño isquémico [Yuan et al. 2003, 401]. Este core necrótico está rodeado de un área donde las células menos afectadas por la isquemia mantienen su metabolismo activo hasta que mueren por apoptosis [Yuan et al. 2003, 401; Broughton et al. 2009, e331; Almeida 2013, 71]. Las neuronas del área de penumbra pueden sufrir apoptosis varias horas e incluso días después del infarto, contribuyendo así a la expansión de la lesión isquémica [Charriaut-Marlangue et al. 
1996, 186; Gomez-Sanchez et al. 2011, 429; Rodríguez et al. 2018, 2437]. La activación de la apoptosis ocurre a través de dos rutas principalmente, llamadas vía extrínseca e intrínseca, que convergen en la activación de la caspasa 3 [Timmer and Salvesen 2007, 66; Sairanen et al. 2009, 541; Almeida 2013, 71]. La vía extrínseca se origina con la activación de receptores de la familia TNF (del inglés Tumor Necrosis Factor), que incluyen el propio TNF y el receptor de muerte Fas, y condiciona la activación de caspasas 8 y 10 iniciadoras que a su vez activarán a las caspasas efectoras 3, 6, 7 [Salvensen and Dixit 1999, 10964]. La vía intrínseca se origina con la liberación de citocromo c de la membrana externa mitocondrial, la activación de la caspasa 9 y formación del apoptosoma [Broughton et al. 2009, e331]. Posteriormente se inicia la cascada de señalización que activa a las caspasas 3 y 7 efectoras, causando daños en el citoesqueleto, proteínas de reparación, metabólicas y de señalización celular. Estas caspasas también fragmentan DNA, lo que contribuye a la muerte celular por apoptosis. La apoptosis ha de estar bien regulada para evitar que las células activen la ruta cuando no proceda. Las proteínas de la familia $\mathrm{Bcl}-2$ son uno de los sistemas reguladores. Incluyen miembros antiapoptóticos y proapoptóticos, cuyo balance determina si la célula vive o activa la vía intrínseca mitocondrial. Las proteínas antiapoptóticas son la propia Bcl-2 y Bcl-xL (Bcl-2-like), que inhiben a las proapoptóticas uniéndose a ellas en el citosol o en la superficie externa de la membrana mitocondrial [Chipuk et al. 2010, 299]. Las proteínas proapoptóticas incluyen Bax (Bcl-2-associated X protein), Bak (Bcl-2 antagonist/killer), Bim (Bcl-2-interacting mediator of cell death) y Bid (BH3intracting-domain death agonist). En el caso de Bax/Bak su agregación favorece la formación de poros en la membrana externa mitocondrial, lo que induce la liberación de moléculas proapotóticas, como el citocromo c, que inicia la activación de las caspasas y la muerte celular por apoptosis [Doyle et al. 2008, 310; Almeida 2013, 71]. En células proliferativas se ha descrito que la magnitud del daño en el DNA induce una cascada de eventos que resultan en una parada del ciclo celular y reparación del DNA o en la apoptosis celular [Bakkenist and Kastan, 2004, 9]. Esto último está mediado por la activación factores de transcripción como p53 o c-myc que inducen la expresión de genes proapoptóticos [Demyanenko and Uzdensky, 2016, 1]. Al igual que la caspasa 3 activa, la proteína p53 es un importante mediador de la apoptosis neuronal inducida por daño en el DNA, hipoxia, falta de nutrientes, hipoglucemia o estrés oxidativo [Culmsee and Mattson 2005, 761]. De modo que p53 parece tener un papel destacado tras un ictus [Culmsee y Mattson, 2005, 761; Gomez-Sanchez et al., 2011, 429; Rodríguez et al. 
2017, 144; Rodríguez et al. 2018, 2437]. Bajo condiciones de estrés, p53 se estabiliza y se activa. Por un lado, es capaz de desencadenar la apoptosis induciendo la expresión de Bax y otras proteínas proapoptóticas como PUMA o NOXA, que actúan en la mitocondria [Miyashita y Reed 1995, 293]. También puede actuar a través de un mecanismo no transcripcional mediante su translocación a la mitocondria e interacción directa con otras proteínas, como Bcl-2 o Bcl-xL, que finalmente causan liberación de citocromo c, activación de caspasas y la muerte celular como ya se ha comentado [Sax et al. 2002, 842; Gomez-Sanchez et al. 2011, 429].

\section{SISTEMAS DE DEFENSA ANTIOXIDANTE CELULAR}

El sistema antioxidante enzimático es la principal línea de defensa celular contra los radicales libres. Entre todas las enzimas implicadas destacan las diferentes formas de superóxido dismutasas, (SODs), la catalasa (CAT) y las enzimas del ciclo redox y síntesis del glutatión: la glutation peroxidasa (GPx), glutation reductasa (GR), glutation- $S$-transferasa (GST) y $\gamma$-glutamilcisteina sintetasa ( $\gamma$-GCS), que colaboran en la regulación del pool intracelular de glutation reducido (GSH), uno de los principales antioxidantes celulares no enzimáticos [Mari et al. 2009, 2685; Hekimi et al. 2011, 569; Quintana-Cabrera et al. 2012]

Las diferentes SODs neutralizan rápidamente el anión superóxido $\left(\mathrm{O}_{2}{ }^{\bullet-}\right)$, formando peróxido de hidrógeno $\left(\mathrm{H}_{2} \mathrm{O}_{2}\right)$ como producto de reacción. Existen tres formas moleculares: SOD-1, que actúa en el citosol y requiere cobre y zinc; SOD-2 o Mn-SOD, en la mitocondria y precisa de manganeso, y la SOD-3, localizada en el espacio extracelular, que depende también de cobre y zinc. La reacción catalizada por la SOD es importante en las células, puesto que el $\mathrm{H}_{2} \mathrm{O}_{2}$ es menos reactivo y más estable que el $\mathrm{O}_{2}{ }^{\circ}$. Además, el $\mathrm{H}_{2} \mathrm{O}_{2}$ puede difundir fácilmente a través de las membranas o ser transportado a través de acuoporinas, lo que convierte a esta molécula en un buen agente señalizador del estado redox celular [Reczek and Chandel 2015, 8; Young et al. 2019, 1285]. Puesto que los niveles elevados de $\mathrm{H}_{2} \mathrm{O}_{2}$ pueden originar radicales hidroxilo $\left({ }^{\circ} \mathrm{OH}\right)$, su regulación y el mantenimiento de concentraciones celulares en un rango adecuado es crucial para su función señalizadora [Reczek and Chandel 2015, 8]. Para ello, las células presentan distintos sistemas antioxidantes que convierten el $\mathrm{H}_{2} \mathrm{O}_{2}$ en $\mathrm{H}_{2} \mathrm{O}$, como son las mencionadas glutatión peroxidasas ( $\left.\mathrm{GPx}\right)$, peroxirredoxinas ( $\mathrm{PRx}$ ) y la catalasa (CAT) (Figura 5). 


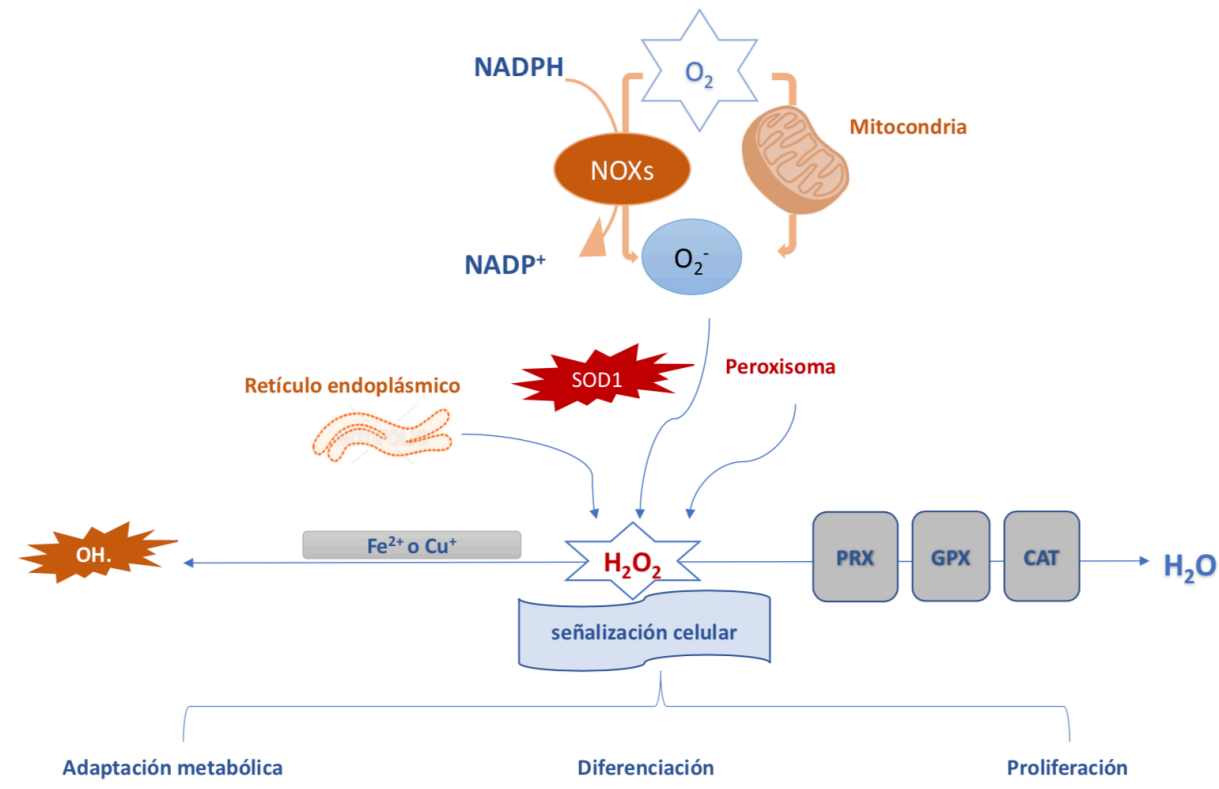

Figura 5. Sistemas antioxidantes celulares (adaptado de Reczek and Chandel 2015, 8).

La catalasa (CAT) se localiza principalmente en los peroxisomas. Es una enzima que contiene hierro en su sitio activo y cataliza la dismutación del $\mathrm{H}_{2} \mathrm{O}_{2}$, originando directamente agua y oxígeno molecular $\left(\mathrm{O}_{2}\right)$ como productos de reacción [Dringen et al. 2005, 157]. La CAT tiene una estructura homotetramérica, cada subunidad posee un grupo hemo que contiene un átomo de Fe y un anillo de porfirina (tetrapirrol) que forman el sitio activo de la enzima [Chelikani et al. 2004, 192].

Las peroxiredoxinas pertenecen a la familia de las peroxidasas. Forman parte del sistema más complejo junto con las tiorredoxinas (TRxs) y tiorreductasas (TRxR). Son enzimas que contienen cisteína en su sitio activo, de modo que la oxidación a Cys-SOH favorece la formación de puentes disulfuro con una cisteína localizada en el extremo C-terminal [D'Autréaux and Toledano 2007, 813]. Estas enzimas reaccionan con el $\mathrm{H}_{2} \mathrm{O}_{2}$ y posteriormente son reducidas por el sistema TRxs/TRxR. Esto requiere un equivalente de NADPH para regenerar los residuos de cisteína de la peroxirredoxina [Holmgren and Lu 2010, 120].

Las glutation peroxidasas (GPx) convierten $\mathrm{H}_{2} \mathrm{O}_{2}$ en $\mathrm{H}_{2} \mathrm{O}$ a expensas del tripéptido glutation (GSH, $\gamma$-glutamil-cisteinil-glicina), que se oxida para formar el disulfuro GSSG (glutatión oxidado). El glutation se regenera gracias a la glutation reductasa (GR), que transfiere electrones del NADPH a GSSG [Dringen et al. 2005, 157]. Por este motivo el NADPH tiene un papel muy importante en el cerebro, especialmente en 
las neuronas, ya que el reciclaje del escaso GSH en estas células es fundamental para su supervivencia [Bouzier-Sore and Bolaños 2015, 1, Jimenez-Blasco et al 2015, 1877].

\section{TRATAMIENTO DEL ICTUS ISQUÉMICO AGUDO EN LA ACTUALIDAD}

La recuperación de las funciones cerebrales después del ictus depende del tamaño del área afectada, la duración de la isquemia, la restauración completa del flujo sanguíneo y la aplicación de medidas destinadas a proteger y reparar el tejido dañado [Brouns and De Deyn 2009, 483]. La estrategia de tratamiento del ictus en su fase aguda tiene dos objetivos principales: normalizar el flujo sanguíneo mediante recanalización, y proteger y reparar los tejidos afectados [Rengel et al., 2018, 90].

Durante la recanalización se intenta restablecer el flujo de sangre (reperfusión) rápidamente en el área del infarto. En la actualidad, esto se puede lograr mediante el tratamiento con la forma recombinante del activador tisular del plasminógeno o t-PA, un trombolítico que es eficaz durante las primeras 6 horas tras la aparición de los síntomas [NINDS 1995, 1581]. Sin embargo, no todos los pacientes cumplen con los criterios de inclusión para este tratamiento farmacológico. En 2004, la Administración de Medicamentos y Alimentos americana (www.fda.gov) aprobó la trombectomía mecánica en pacientes con ictus que no son candidatos para la trombolisis sistémica, o como tratamiento de rescate en pacientes que no responden a la terapia intravenosa utilizando t-PA [Ramee et al. 2004, e109; Bergui et al. 2005, 145]. Ambas estrategias de trombolisis y trombectomía se pueden combinar en algunos casos [Smith et al., 2008, 1205], aunque en los últimos años se ha demostrado que la trombectomía endovascular o la retirada del trombo mediante un dispositivo mecánico es el tratamiento más eficaz para la recanalización después del ictus [Goyal et al. 2016, 1723].

La reperfusión es, por tanto, fundamental para restablecer la función cerebral. Sin embargo, se asocia con un aumento significativo en las especies de nitrógeno y oxígeno reactivo, como el anión superóxido $\left(\mathrm{O}^{2 \bullet-}\right)$, el peróxido de hidrógeno $\left(\mathrm{H}_{2} \mathrm{O}_{2}\right)$ o el radical hidroxilo $\left({ }^{\circ} \mathrm{OH}\right)$, que participarán en lo que se conoce como "daño por reperfusión" [Granger and Kvietys, 2015, 255]. Este daño por reperfusión incluye estrés oxidativo, infiltración de leucocitos, agregación plaquetaria, activación del complemento y mitocondrial, así como disrupción de la barrera hematoencefálica que puede dar lugar a edema y transformación hemorrágica en el cerebro [Eltzschig and Eckle 2011, 1391; 
Granger and Kvietys 2015, 524]. Para evitar el daño tisular producido por los radicales libres y minimizar la respuesta inflamatoria, la terapia de recanalización debería ir acompañada de tratamientos que reduzcan los procesos de neurodegeneración. Así, la terapia antioxidante podría ser importante en este punto para proteger el tejido cerebral dañado, de ahí el interés en la neuroprotección para mejorar el pronóstico de pacientes de ictus [Rachel et al. 2014, 472; Chamorro et al. 2016, 869].

El objetivo de las terapias neuroprotectoras es preservar la estructura y función de las neuronas, fomentando la supervivencia celular en la zona de penumbra. En los últimos años se han completado con éxito numerosos estudios preclínicos empleando sustancias neuroprotectoras [Campos et al. 2011, 1378; Sutherland et al. 2012, 407; Castillo et al. 2016, 292] y otras aproximaciones como la hipotermia [van der Worp 2007, 3063; Campos et al. 2012, 495], capaces de reducir la tasa metabólica e inhibir la producción de radicales libres de oxígeno reduciendo el daño oxidativo tras la isquemia/reperfusión. Sin embargo, estos resultados no son fácilmente reproducibles en humanos [Sutherland et al. 2012, 407; Wiendl et al. 2015, 449; Nagy and Nardai 2017, 30]. En el caso del ictus, un tratamiento neuroprotector ideal debería actuar en varios puntos de la cascada isquémica para potenciar su efectividad y hacerlo rápidamente después del daño [Wiendl et al. 2015, 449].

\subsection{Controversia sobre la terapia antioxidante en ictus}

La secuencia de acontecimientos que tienen lugar después de la reperfusión farmacológica o mecánica tras un ictus da lugar a una producción de ROS que supera la capacidad antioxidante de las células. Como se ha sugerido en el apartado anterior, las terapias antioxidantes, en combinación con la trombolisis e incluso otros agentes neuroprotectores, podrían representar una alternativa para reducir el daño oxidativo ocasionado por estos fenómenos [Shirley et al. 2014, 472]. Las estrategias antioxidantes podrían aumentar la producción de antioxidantes endógenos o bien la liberación de antioxidantes exógenos. En cualquier caso, se podría i) frenar la producción de radicales libres, ii) aumentar el "scavenging" de estos radicales o iii) fomentar su degradación [Margaill 2005, 429].

El uso de inhibidores de enzimas generadoras de ROS, como las NADPH oxidasas (NOX), ha permitido estudiar su relevancia en la isquemia. La inhibición de NOX con agentes farmacológicos [Tang et al. 2007, 517] o mediante modelos animales knock- 
out [Chen et al. 2009, 1262; Kleinschnitz et al. 2010] ha demostrado la contribución de NOX2 y NOX4 al daño cerebral in vivo. Sin embargo, no está claro que NOX1 juegue un papel importante [Kleinschnitz et al. 2010]. El desarrollo de inhibidores específicos para estas dos isoformas podría ser, por tanto, de gran utilidad en ictus [Chamorro 2018, 197].

Existen también compuestos capaces de secuestrar radicales libres como el peroxinitrito (ej. NXY-059) que han sido eficaces en modelos animales. En clínica, por el contrario, su aplicación a las 6 horas del ictus no demostró tener el mismo efecto [Chamorro et al. 2016, 869]. Compuestos como la edaravona, que secuestra principalmente radical ${ }^{\circ} \mathrm{OH}$, se están aplicado desde hace años en Asia, aunque los resultados de los estudios clínicos tampoco son concluyentes [Yang et al. 2006, 18]. Es posible que la dosis y la ventana terapéutica sean responsables de la variabilidad observada con estos tratamientos. Otros compuestos con propiedades antioxidantes que han demostrado ser neuroprotectores en modelos preclínicos son los análogos sintéticos de la vitamina E, como el CR-6. Esta molécula es capaz de secuestrar especies reactivas de nitrógeno, aunque su efectividad en clínica todavía no ha sido demostrada [Sutherland et al. 2012, 407]. La toxicidad del peroxinitrito también se ha intentado prevenir de manera indirecta bloqueando la generación de oxido nítrico (NO) y anión superóxido $\left(\mathrm{O}^{2 \cdot-}\right)$.

Las estrategias para fomentar la degradación de radicales libres incluyen la sobreexpresión de SODs. Empleando animales transgénicos se ha visto que SOD-1 y SOD-2 (Mn-SOD mitocondrial) podrían tener un efecto neuroprotector frente al estrés oxidativo inducido por modelos de oclusión transitoria de la arteria cerebral media (MCAO, del inglés Middle Cerebral Artery Occlusion) [Fujimura et al. 1999, 2408; Fujimura et al. 2000, 2817; Kim et al. 2002, 809; Maier et al. 2006, 1366]. El uso de glutatión peroxidasa (GPx) o catalasa (CAT) podría aumentar la eficiencia de las SODs [Ishibashi 2002, 34; Gu 2004, 413]. La sobreexpresión de GPx efectivamente reduce la muerte celular por necrosis y apoptosis, la activación de astrocitos y microglia y, por tanto, la respuesta inflamatoria [Ishibashi 2002,34]. Sin embargo, no está claro su papel para mejorar el pronóstico en isquemia/reperfusión. Por otro lado, aunque se ha descrito un modelo experimental de sobreexpresión de catalasa [Chen et al. 2003, 219], su impacto en el contexto de la isquemia cerebral es totalmente desconocido.

El fallo de los suplementos vitamínicos en ictus y de las terapias antioxidantes en general podría explicarse, en parte, por la dificultad de alcanzar una concentración 
suficiente de estos compuestos en la localización intracelular adecuada [Murphy 2014, 20]. El uso de antioxidantes dirigidos específicamente a la mitocondria, principal orgánulo productor de ROS en la célula, como MitoQ o la propia vitamina E (MitoVitE) podría prevenir la apoptosis causada por el incremento de ROS [Oyewole and BirchMachin 2015, 4766]. Por tanto, este tipo de estrategias dirigidas podrían ser importantes para el desarrollo de nuevos tratamientos en ictus. 


\section{HIPÓTESIS}

Tras un ictus, la reperfusión temprana del cerebro isquémico es actualmente la mejor aproximación terapéutica. En este sentido, el tratamiento endovascular mediante trombectomía mecánica ha demostrado su eficacia en oclusiones de gran vaso. Sin embargo, aunque la revascularización se produce en aproximadamente $60-80 \%$ de los pacientes, hay un $40 \%$ de ellos que presentan mal pronóstico. El daño por reperfusión asociado al estrés oxidativo podría, por tanto, contribuir al daño neuronal impidiendo la recuperación del tejido isquémico. Por ello, consideramos que una terapia antioxidante coadyuvante a la recanalización podría prevenir el daño neuronal y, con ello, mejorar el pronóstico funcional de los pacientes de ictus. Es más, creemos que el diseño de nuevas estrategias terapéuticas dirigidas a la mitocondria -principal orgánulo productor de ROS- podría ser fundamental para reducir de una manera más eficiente los ROS generados durante la reperfusión y favorecer así la recuperación de la función cerebral tras la isquemia. 


\section{OBJETIVOS}

Teniendo presente nuestra hipótesis de trabajo, nuestro objetivo fundamental ha sido investigar la posible función neuroprotectora de la terapia antioxidante dirigida a la mitocondria en la isquemia cerebral, mediante la generación de un modelo murino que expresa, de manera constitutiva, la enzima antioxidante catalasa en la mitocondria (mCAT).

En concreto, proponemos los siguientes objetivos específicos:

1. Estudiar el efecto de la expresión de catalasa en la mitocondria (mCAT) sobre la diferenciación neuronal in vitro

2. Evaluar la capacidad neuroprotectora de la terapia antioxidante dirigida a la mitocondria en la excitotoxicidad in vitro, inducida mediante la estimulación con glutamato e isquemia experimental en neuronas corticales

3. Investigar el efecto neuroprotector de la terapia antioxidante dirigida a la mitocondria en la isquemia cerebral in vivo 


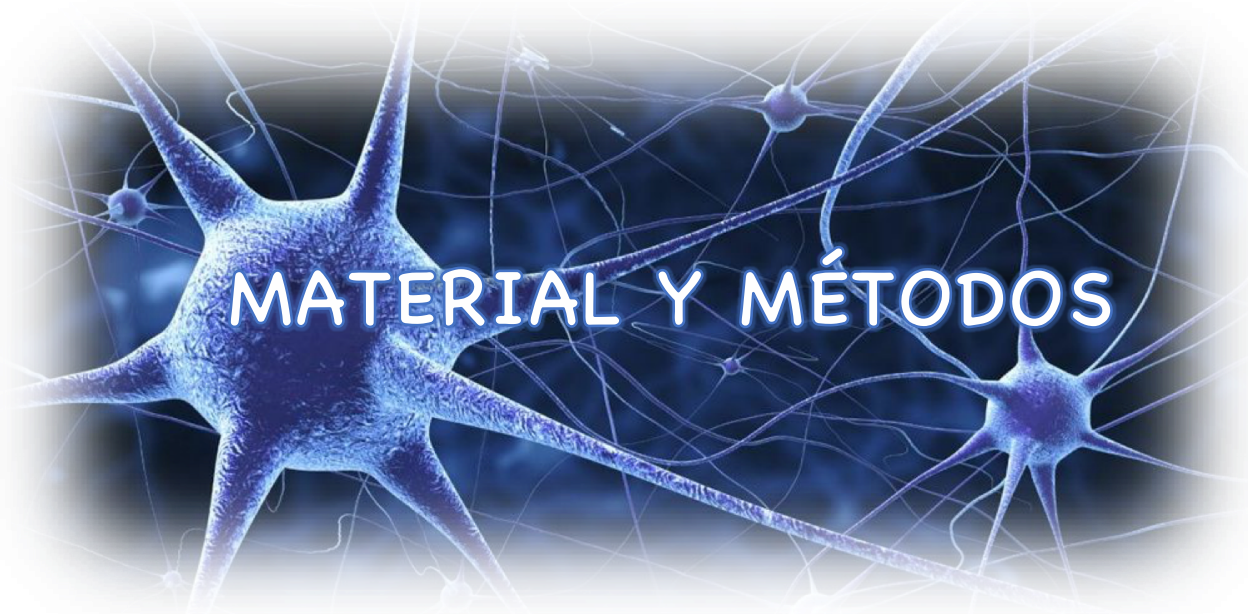




\section{ANIMALES DE EXPERIMENTACIÓN}

Todos los procedimientos con animales cumplen la recomendación 2007/526/EC, de 18 de junio de 2007, de la Comisión Europea relativa al alojamiento y cuidado de animales, así como la legislación española vigente RD53/2013, de 1 de febrero de 2013, por el que se establecen las normas básicas aplicables para la protección de los animales utilizados en experimentación y otros fines científicos. Además, todos los protocolos de la presente Tesis que implican manipulación de animales vivos han sido aprobados por el Comité de Bioética del Instituto de Investigación Biomédica de Salamanca.

\subsection{Modelo de ratón mCAT}

Para el desarrollo de este trabajo se ha empleado un modelo de ratón knock-in que expresa catalasa mitocondrial (mCAT) de forma constitutiva, lo que permite modular a la baja la abundancia de ROS mitocondriales (mROS) endógenos [Vicente-Gutierrez, 2019].

El modelo transgénico se generó a partir de cDNA mCAT, que codifica la catalasa fusionada a la secuencia $N$-terminal de localización mitocondrial de la citocromo c oxidasa VIII (C8) y la secuencia de cDNA de la hemaglutinina (HA) del virus de la influenza para su seguimiento (Figura 6). El cDNA mCAT se introdujo mediante recombinación homóloga en el locus Rosa26 en un fondo C57Bl/6J (genOway, France). De este modo se aseguró (i) la inserción de una única copia de la construcción mCAT en un locus determinado, (ii) la expresión controlada de la construcción mCAT y (iii) el mantenimiento de la catalasa endógena (citosólica) intacta.

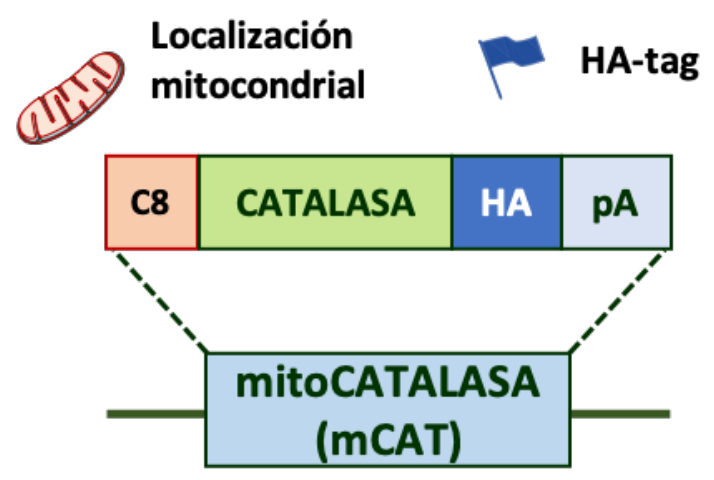

Figura 6. Construcción de catalasa mitocondrial (mCAT). C8: citocromo c oxidasa VIII; HA: hemaglutinina de influenza humana; pA: cola poli-A; mCAT: catalasa mitocondrial. 
Adicionalmente, también se incluyó una secuencia de parada (STOP) flanqueada por secuencias LoxP (5'-ATAACTTCGTATAATGTATGCTATACGAAGTTAT-3') (Locus of X-over Pl) (Branda y Dymecki, 2004) entre el cDNA de la catalasa mitocondrial y el promotor $\mathrm{CAG}$, lo que permitiría expresar la catalasa mitocondrial de forma tejido-específica o en un tiempo concreto (Figura 7). El ratón generado de esta manera (mCATLoxP/+) con fondo $\mathrm{C} 57 \mathrm{Bl} / 6 \mathrm{~J}$, fue cruzado con ratones que expresan Cre recombinasa derivada del fago P1 bajo el promotor CMV (CMV-Cre/+) (Figura 2b) para eliminar la secuencia de STOP y expresar la catalasa mitocondrial de forma constitutiva (mCAT/+ o mCAT) (Figura 2c). Para los experimentos realizados en la presente Tesis, se cruzaron animales heterocigotos (mCAT/+ o mCAT) con ratones C57Bl/6J para realizar experimentos con animales mCAT/+ (mCAT) y +/+ (wt).

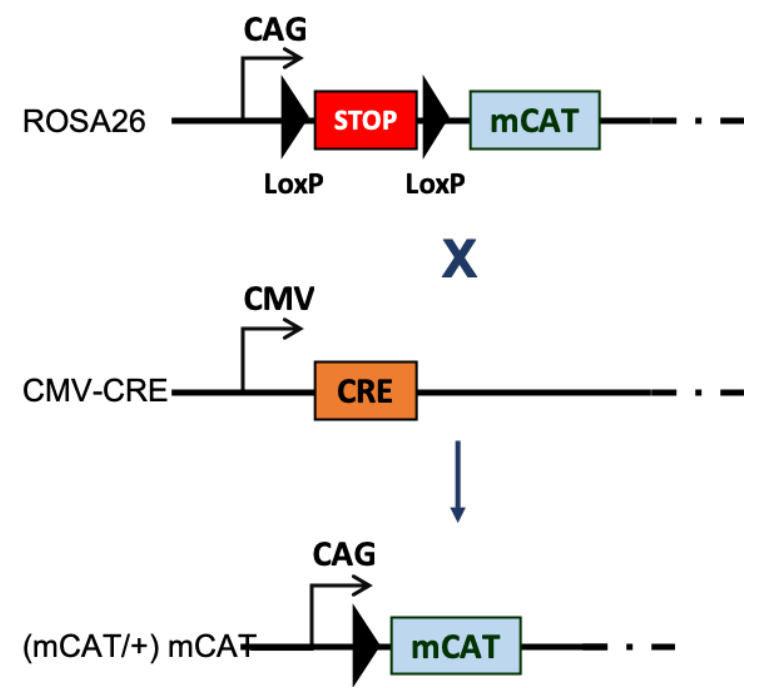

Figura 7. Estrategia utilizada para expresar de manera ubicua la catalasa en la mitocondria. pA: cola poli-A; mCAT: catalasa mitocondrial; CAG: potenciador del citomegalovirus fusionado con el promotor de la actina b de pollo; CMV: citomegalovirus.

Los animales se criaron en las instalaciones del Servicio de Experimentación Animal de la Universidad de Salamanca (máximo 5 animales/jaula) manteniendo un ciclo de luz-oscuridad durante 12 horas. La humedad estuvo entre $45 \%$ y $65 \%$ y la temperatura entre $20^{\circ} \mathrm{C}$ y $25^{\circ} \mathrm{C}$. Los animales se alimentaron ad libitum con una dieta sólida estándar (17\% de proteínas, $3 \%$ de lípidos, $58,7 \%$ de carbohidratos, $4,3 \%$ de celulosa, $5 \%$ de minerales y $12 \%$ de humedad) con acceso libre al agua.

El periodo gestacional, establecido en 19,5 días para el ratón, se controló limitando la cohabitación de ratones hembra con machos a una noche. A las 9:00 horas del día siguiente, se aislaron hembras con presencia de espermatozoides en el frotis vaginal 
acompañados por células epiteliales de la vagina (tapón vaginal indicador de copulación exitosa) y se consideró este día como el primero de la etapa gestacional.

\subsection{Extracción de ADN}

El ADN se extrajo de un pequeño fragmento de la cola de ratones recién nacidos o bien de embriones de 14,5 días en el momento de cultivo (2-3 $\mathrm{mm}$ de largo). El tejido se incubó con $200 \mu \mathrm{l}$ de tampón de lisis (buffer TEN: Tris $50 \mathrm{mM} \mathrm{pH} \mathrm{7,5,} \mathrm{EDTA} 5 \mathrm{mM}$ pH $8, \mathrm{NaCl} 100 \mathrm{mM}$, que contiene DTT $1 \mathrm{mM}$ y espermidina $0,5 \mathrm{mM}$ ) y $5 \mu \mathrm{de}$ proteinasa K (800 U/ $\mu$; Sigma-Aldrich). Para una digestión completa la reacción se dejó en agitación durante la noche a $55^{\circ} \mathrm{C}$. Al día siguiente las muestras se incubaron durante 5 minutos a $100^{\circ} \mathrm{C}$ y se centrifugaron a 13,000 rpm durante 5 minutos. La concentración de DNA se determinó usando NanoDrop 2000 (Thermo Fisher)

\subsection{Genotipado}

Los ratones mCAT fueron genotipados mediante PCR. Se utilizaron los oligonucleótidos 124540-BOL1 (forward) $\quad 5^{\prime}-$ CTCCCAAAGTCGCTCTGAGTTGTTATAT-3' y 124541-BOL1 (reverso) 5'CGATTTGTACGTAACTAATCTGTCTGG-3', generando una banda de 778 pb en el alelo silvestre (wt) y una de 5949 pb en el alelo mCat, difícil de detectar por su gran tamaño. Por ello, para detectar la construcción de mCAT, se utilizó un tercer oligonucleótido 0034-Kin-ROSA, 5'-GCAGTGAGAAGAGTACCACCATGAGTCC3 ', que generó una banda de 245 pb (Figura 8).
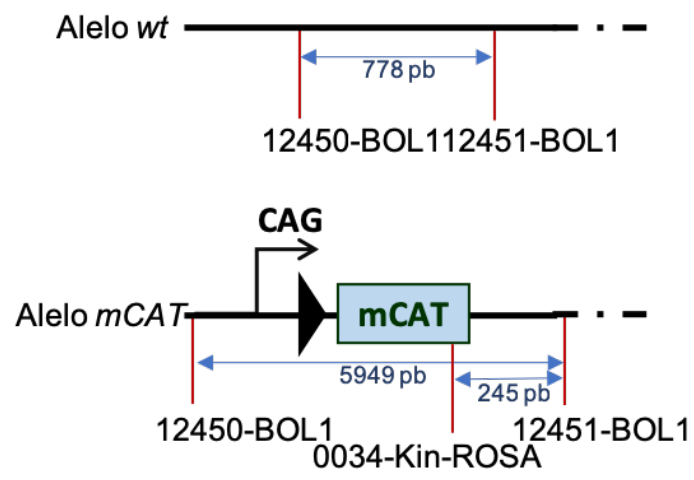

Figura 8. Estrategia de genotipado de animales mCAT por PCR. Las líneas rojas ilustran la localización de los oligonucleótidos.

Las condiciones de la PCR fueron: 5 minutos a $95^{\circ} \mathrm{C}, 35$ ciclos de 30 segundos a $95^{\circ} \mathrm{C}$ seguidos de 30 segundos a $65^{\circ} \mathrm{C}$ y 3 minutos a $72^{\circ} \mathrm{C}$ y un paso final de 8 minutos a 
$72^{\circ} \mathrm{C}$. Las concentraciones finales de los componentes de la PCR fueron una mezcla de dNTPs $0.5 \mathrm{mM}$ (Roche), oligonucleótidos $0.3 \mu \mathrm{M}$ (Sigma-Aldrich), Taq polimerasa $0.042 \mathrm{U} / \mu \mathrm{l}$ (Biotools) y un tampón de reacción $1 \mathrm{X}$ que contiene $\mathrm{MgCl}_{2}$. La cantidad total de DNA empleado fue de $30 \mathrm{ng}$.

\subsection{Electroforesis en gel}

Los productos de PCR se analizaron en un gel de agarosa al 2\% (p/v) (Sigma-Aldrich). Los geles se tiñeron previamente con MidoriGreen (1:20.000) y la electroforesis se realizó en tampón TAE (Tris $40 \mathrm{mM}$, ácido acético glacial $20 \mathrm{mM}, \mathrm{Na}_{2} \mathrm{EDTA} \cdot 2 \mathrm{H}_{2} \mathrm{O} 1$

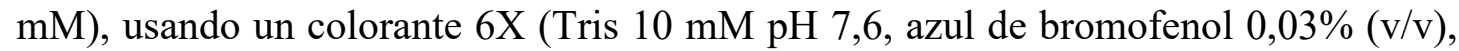
xileno cianol 0,03\%, glicerol $60 \%, \mathrm{Na}_{2}$ EDTA $\bullet 2 \mathrm{H}_{2} \mathrm{O} 60 \mathrm{mM}$ ) para cargar el DNA. Las imágenes fueron tomadas usando Bio-Rad Chemidoc.

\section{CULTIVOS CELULARES}

\subsection{Cultivo primario de Neuronas}

Las neuronas en el cultivo primario se obtuvieron de embriones de 14.5 días de gestación (E14.5) procedentes de la línea mCAT constitutiva con fondo genético C57Bl/J6 [Almeida et al., 1998, Gómez-Sánchez et al. 2011]. Las ratonas gestantes se sacrificaron mediante dislocación cervical y se extrajeron los embriones mediante histerectomía. Los embriones se transfirieron a una cabina de flujo laminar (TC48, Gelaire Flow Laboratories) para mantener las condiciones estériles del cultivo. Con ayuda de tijeras, fórceps y pañuelos impregnados en 70\% de etanol, se extrajeron los hemisferios cerebrales. Luego se colocó el tejido cerebral en una placa Petri de poliestireno con la solución de disgregación [EBSS (Eagle's Basal Salt Solution: $\mathrm{NaCl}$ $116 \mathrm{mM}, \mathrm{KCl} 5,4 \mathrm{mM}, \mathrm{NaH}_{2} \mathrm{PO}_{4}$ 1,01 mM, MgSO 4 1,5 mM, NaHCO 326 mM, Dglucosa $4 \mathrm{mM}, 10 \mathrm{mg} / \mathrm{ml}$ de rojo fenol) con 2,94 mg/ml de BSA (albúmina de suero bovino) y $20 \mu \mathrm{g} / \mathrm{ml}$ de DNAsa tipo I, $\mathrm{pH} 7,15]$ y se diseccionó suavemente con un bisturí. A continuación, se colocó cada cerebro de embrión diseccionado en un eppendrof y se dejó durante 4 minutos para la sedimentación. El sedimento se resuspendió en solución de tripsinización (EBSS; $50 \mu \mathrm{g} / \mathrm{ml}$ de DNAsa, 3,15 mg/ml de BSA, $10 \mathrm{mg} / \mathrm{ml}$ de tripsina, $\mathrm{pH} 7,15$ ) y se incubó a $37^{\circ} \mathrm{C}$ durante 10 minutos en un baño termostático. La tripsinización se detuvo añadiendo FBS (suero fetal de ternera) a una concentración final de 10\% (v/v). La suspensión celular se centrifugó a 500 x g durante 
5 minutos para eliminar el sobrenadante (Eppendorf 5702R, Eppendorf). El sedimento se resuspendió suavemente (unas 9 veces) en $1 \mathrm{ml}$ de solución de disgregación con una pipeta Pasteur siliconada para evitar la rotura celular. Después de dejar sedimentar la solución celular durante 4 minutos, se recogió el sobrenadante, que contenía las células disociadas, y se depositó en un eppendorf nuevo. Este proceso de resuspensión se repitió una vez más para aumentar el rendimiento. Los sobrenadantes se centrifugaron luego a $500 \mathrm{x}$ g durante 5 minutos.

El sedimento celular se resuspendió en un medio específico para el crecimiento neuronal Neurobasal ${ }^{\mathrm{TM}}$-A (Life Technologies) suplementado con 2\% de B27-AO (AntiOxidants, Life Technologies), L-glutamina $2 \mathrm{mM}$, D-glucosa 5,5 mM, piruvato 2,5 mM y antibióticos: penicilina G $100 \mathrm{U} / 1$; estreptomicina $100 \mu \mathrm{g} / 1$; anfotericina B 0,25 $\mu \mathrm{g} / 1$ (Sigma-Aldrich). Para prevenir contaminación por micoplasma se realizó un tratamiento con Plasmocin $2.5 \mu \mathrm{g} / \mathrm{ml}$ (Invivo Gen). Para el recuento de células vivas se realizó una tinción con azul de tripano al 0,4\% (10 $\mu 1$ de la suspensión celular en $30 \mu 1$ medio de cultivo y $40 \mu \mathrm{l}$ de azul de tripano) (Sigma-Aldrich), y se utilizó una cámara Neubauer (Zeiss) y un microscopio de contraste de fases (Olympus CK30). La suspensión celular se sembró a una densidad de $2 \times 10^{5}$ células $/ \mathrm{cm}^{2}$ en placas de poliestireno (Nunc ${ }^{\mathrm{TM}}$, Thermo Fischer Scientific), previamente recubiertas con poli-Dlisina (10 $\mu \mathrm{g} / \mathrm{ml}$; Sigma-Aldrich). Las placas se colocaron en un incubador de cultivo celular termostatizado a $37^{\circ} \mathrm{C}$ en atmósfera húmeda al 5\% de $\mathrm{CO} 2$. El medio se renovó a los tres días in vitro (3DIV) se reemplazó el medio por Neurobasal-A suplementado con 2\% de B27-MAO (Minus AntiOxidants, Life Technologies), L-glutamina 2 mM, Dglucosa 5,5 mM, piruvato 2,5 mM y antibióticos (penicilina G $100 \mathrm{U} / 1$; estreptomicina $100 \mu \mathrm{g} / \mathrm{l}$; anfotericina B 0,25 $\mu \mathrm{g} / \mathrm{l})$, tratado también con Plasmocin $(2.5 \mu \mathrm{g} / \mathrm{ml})$. Las neuronas se utilizaron a los 8-9DIV para experimentos, momento en que se sabe expresan receptores sinápticos funcionales [Almeida et al., 2002].

\section{MODELOS DE EXCITOTOXICIDAD IN VITRO}

La producción de ROS por la mitocondria en célula entera se indujo mediante incubación de las neuronas con el neurotransmisor excitador glutamato a una concentración excitotóxica de $100 \mu \mathrm{M}$ (Sigma) en tampón Hank's con glucosa 5,5 mM $\left(\mathrm{NaCl} 134,2 \mathrm{mM}, \mathrm{KCl} \quad 5,26 \mathrm{mM}, \mathrm{KH}_{2} \mathrm{PO}_{4} \quad 0,43 \mathrm{mM}, \mathrm{NaHCO}_{3} \quad 4,09 \mathrm{mM}\right.$, $\mathrm{Na}_{2} \mathrm{HPO}_{4} \cdot 2 \mathrm{H}_{2} \mathrm{O}$ 0,33 mM, HEPES $20 \mathrm{mM}, \mathrm{CaCl}_{2} \cdot 2 \mathrm{H}_{2} \mathrm{O} 4 \mathrm{mM}$ y D-glucosa $5.5 \mathrm{mM}$ a 
pH 7.4) y antibióticos (penicilina G $100 \mathrm{U} / \mathrm{l}$; estreptomicina $100 \mu \mathrm{g} / \mathrm{l}$; anfotericina $\mathrm{B}$ $0,25 \mu \mathrm{g} / \mathrm{l}$ ), y en presencia de glicina $10 \mu \mathrm{M}$ (Sigma). Tras 10 minutos de incubación a $37^{\circ} \mathrm{C}$ y atmósfera estándar de cultivo (aire $95 \% / \mathrm{CO}_{2} 5 \%, \mathrm{O}_{2} 21 \%$ ) en estas condiciones (tiempo de estimulación), se reemplazó el medio y las células se incubaron durante 0 , 2, 4 y 24 horas (tiempo post-estimulación) en Neurobasal ${ }^{\mathrm{TM}}$-A suplementado con $2 \%$ de B27-MAO (Minus AntiOxidants), L-glutamina $2 \mathrm{mM}$, D-glucosa 5,5 mM, piruvato 2,5 mM y antibióticos (penicilina G $100 \mathrm{U} / 1$; estreptomicina $100 \mu \mathrm{g} / \mathrm{l}$; anfotericina B $0,25 \mu \mathrm{g} / \mathrm{l})$.

Paralelamente, como control, se llevó a cabo la incubación de neuronas del mismo cultivo primario en ausencia de glutamato, manteniendo el resto de condiciones: medio Hank's con D -glucosa 5,5 mM y antibióticos, en presencia de glicina $10 \mu \mathrm{M}$, a $37^{\circ} \mathrm{C}$ durante 10 minutos y en atmósfera estándar de cultivo (aire 95\%/ $\mathrm{CO}_{2} 5 \%, \mathrm{O}_{2} 21 \%$ ). Las condiciones y tiempos de post-estimulación se realizaron del mismo modo en ambas condiciones.

\section{MODELO DE ISQUEMIA EXPERIMENTAL IN VITRO}

El protocolo de isquemia experimental consiste en privar a las células del oxígeno y la glucosa presentes en el medio durante un tiempo determinado para, posteriormente, reoxigenarlas en un medio de cultivo completo, asemejando así un proceso de reperfusión [Almeida et al. 2002; Gómez-Sánchez et al. 2011] Para ello, el medio de cultivo se sustituyó por Neurobasal ${ }^{\mathrm{TM}}-\mathrm{A} \sin \mathrm{B} 27$ y $\sin$ glucosa, suplementado únicamente con L-glutamina $2 \mathrm{mM}$, piruvato $2,5 \mathrm{mM}$ y antibióticos (penicilina $\mathrm{G} 100$ $\mathrm{U} / 1$; estreptomicina $100 \mu \mathrm{g} / \mathrm{l}$; anfotericina B $0,25 \mu \mathrm{g} / \mathrm{l}$ ). Las células se incubaron a $37^{\circ} \mathrm{C}$ en ausencia de oxígeno $\left(\mathrm{N}_{2} 95 \% / \mathrm{CO}_{2} 5 \%, \mathrm{O}_{2}<1 \%\right)$ durante 90 minutos. Tras ese tiempo se retiró el medio de isquemia y se mantuvieron las células en Neurobasal ${ }^{\mathrm{TM}}-\mathrm{A}$ suplementado con 2\% de B27-MAO (Minus AntiOxidants), L-glutamina 2 mM, Dglucosa 5,5 mM, piruvato 2,5 mM y antibióticos (penicilina G $100 \mathrm{U} / 1$; estreptomicina $100 \mu \mathrm{g} / \mathrm{l}$; anfotericina B 0,25 $\mu \mathrm{g} / \mathrm{l})$. Durante la reoxigenación $(0,2,4,24 \mathrm{~h})$ las neuronas se incubaron en atmósfera estándar de cultivo (aire 95\%/CO $\mathrm{CO}_{2} 5 \%, \mathrm{O}_{2} 21 \%$ ). Esta condición, que permite modelizar aspectos metabólicos de la isquemia in vitro, será la denominada OGD (Oxygen and Glucose Deprivation).

Paralelamente, se llevó a cabo la condición control o normoxia (NMX) del mismo cultivo primario de neuronas. En este caso las células se cultivaron en medio 
Neurobasal ${ }^{\mathrm{TM}}$-A sin $\mathrm{B} 27$ y con D-glucosa $5,5 \mathrm{mM}$, además de L-glutamina $2 \mathrm{mM}$, piruvato 2,5 mM y antibióticos (penicilina G $100 \mathrm{U} / \mathrm{l}$; estreptomicina $100 \mu \mathrm{g} / \mathrm{l}$; anfotericina B 0,25 $\mu \mathrm{g} / \mathrm{l}$ ) y se incubaron en atmósfera estándar de cultivo (aire $95 \% / \mathrm{CO}_{2}$ $5 \%, \mathrm{O}_{2} 21 \%$ ) durante los mismos tiempos que la condición de isquemia (OGD). Se procedió a la reoxigenación del mismo modo en ambas condiciones.

\section{DETERMINACIÓN DE LA CONCENTRACIÓN DE Ca2+ INTRACELULAR}

Para estimar los cambios en la concentración de $\mathrm{Ca}^{2+}$ libre intracelular en cultivo primario de neuronas, se empleó la sonda fluorescente Fura-2AM (Fura-2AcetoxiMetil éster; Life Technologies), un indicador excitable mediante luz UV que es permeable a la membrana plasmática [Jiménez-Blasco et al 2015, 1877]. Tras la unión del $\mathrm{Ca}^{2+}$ con Fura-2, el máximo de excitación de fluorescencia fluctúa de $380 \mathrm{~nm}$ (libre de $\mathrm{Ca}^{2+}$ ) a $340 \mathrm{~nm}$ (saturado de $\mathrm{Ca}^{2+}$ ), mientras que el máximo de emisión de fluorescencia se mantiene inalterado a $\sim 505 \mathrm{~nm}$ (Figura 9).

Las neuronas de 8 DIV sembradas en placas de 12 pocillos $\left(\mathrm{Nunc}^{\mathrm{TM}}\right)$ y se incubaron en presencia de Fura-2AM (2 mM; disuelto en DMSO) durante 30 minutos en Neurobasal ${ }^{\mathrm{TM}}-\mathrm{MAO}$ a $37^{\circ} \mathrm{C}$. Posteriormente, se lavaron y se incubaron con Buffer Estándar $(\mathrm{NaCl} 140 \mathrm{mM}, \mathrm{KCl} 2.5 \mathrm{mM}$, Tris- $\mathrm{HCl} 15 \mathrm{mM}$, D-glucosa $5 \mathrm{mM}$, $\mathrm{Na}_{2} \mathrm{HPO}_{4} \cdot 2 \mathrm{H}_{2} \mathrm{O} 1.2 \mathrm{mM}, \mathrm{MgSO}_{4} 1 \mathrm{mM}$ y $\mathrm{CaCl}_{2} 1 \mathrm{mM}, \mathrm{pH}$ 7.4) durante 30 minutos a $37^{\circ} \mathrm{C}$. Posteriormente, se realizó un cambio de medio para incubar las neuronas en Buffer Experimental (NaCl 140 mM, KCl 2.5 mM, Tris-HCl 15 mM, D-glucosa 5 mM, $\mathrm{Na}_{2} \mathrm{HPO}_{4} \cdot 2 \mathrm{H}_{2} \mathrm{O} 1 \mathrm{mM} \mathrm{y} \mathrm{CaCl} 22 \mathrm{mM}$, pH 7.4), en presencia o en ausencia del inhibidor MK801 $(10 \mu \mathrm{M})$ que se usó como control.

Las emisiones de fluorescencia a $505 \mathrm{~nm}$, después de las excitaciones a 340 y $380 \mathrm{~nm}$, respectivamente, se registraron a intervalos de 0,7 segundos en un espectrofluorímetro (Varioskan Flash, Thermo Fischer) a $32^{\circ} \mathrm{C}$. Después de 10 medidas (10 segundos aproximadamente), se añadió glicina $10 \mu \mathrm{M}$ y, adicionalmente en los pocillos problema, se añadió glutamato $100 \mu \mathrm{M}$ o NMDA $100 \mu \mathrm{M}$ (agonista de receptores glutamatérgicos de NMDA) según corresponda. Las emisiones se registraron durante otros 15 segundos. Los cambios en la concentración de $\mathrm{Ca}^{2+}$ intracelular se estimaron calculando el ratio de la fluorescencia emitida a $505 \mathrm{~nm}$, obtenida después de la excitación a $340 \mathrm{~nm}$, dividida por la obtenida después de la excitación a $380 \mathrm{~nm}$ 
(F340/F380). El ruido de fondo se determinó a partir de los valores obtenidos en las células carentes de Fura-2AM (incubadas únicamente en presencia del vehículo, DMSO). En experimentos preliminares, la especificidad al $\mathrm{Ca}^{2+}$ de las medidas se testó en Buffer Experimental libre de $\mathrm{Ca}^{2+}$, con EDTA $1 \mathrm{mM}$, lo que previno completamente los cambios de fluorescencia emitida a $505 \mathrm{~nm}$.
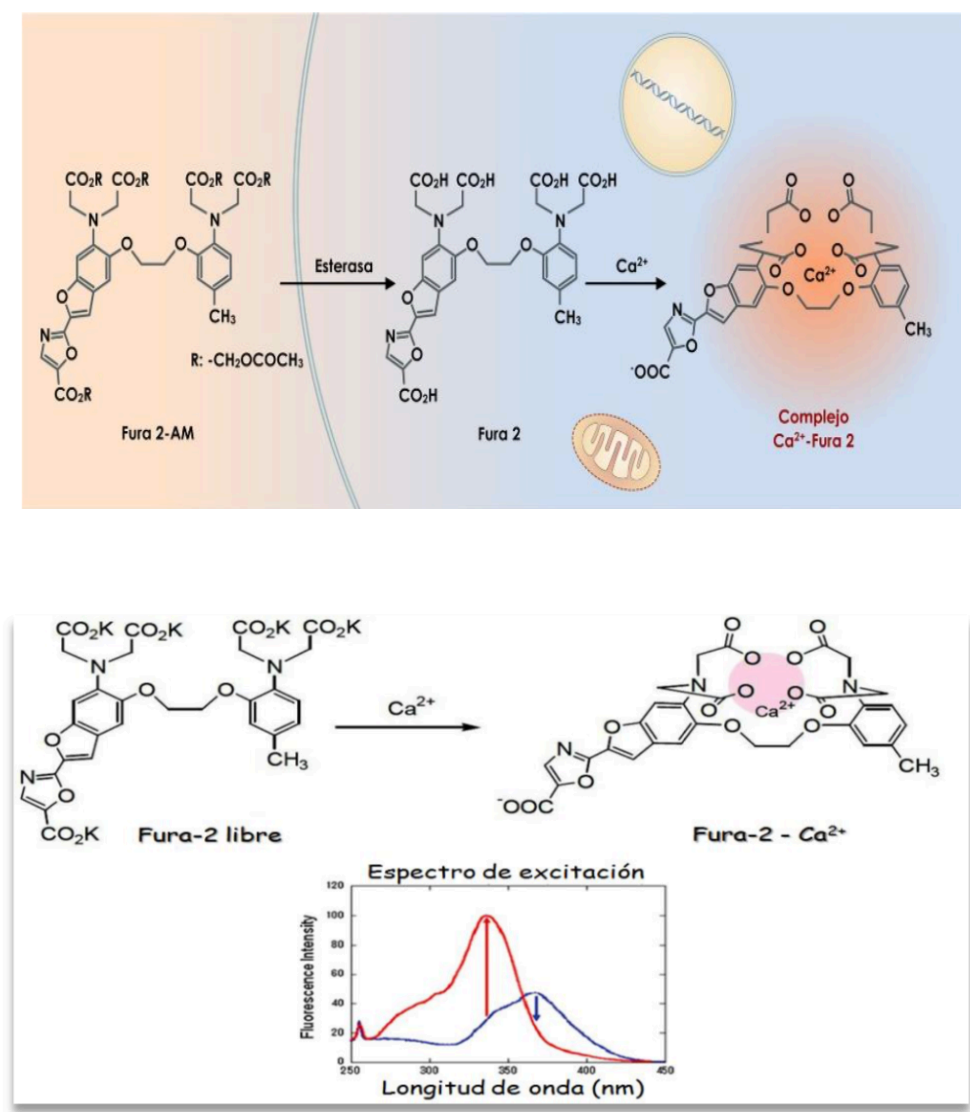

Figura 9. Detección de $\mathrm{Ca}^{2+}$ intracelular con la sonda Fura-2AM. La unión de $\mathrm{Ca}^{2+}$ a la sonda produce cambios en la fluorescencia de excitación, de $380 \mathrm{~nm}$ (azul), cuando la sonda está libre de $\mathrm{Ca}^{2+}$, a $340 \mathrm{~nm}$ (rojo) cuando la sonda está unida a $\mathrm{Ca}^{2+}$.

\section{DETERMINACIÓN DE LAS ESPECIES REACTIVAS DE OXÍGENO}

\subsection{Detección de peróxido de hidrógeno}

La producción de $\mathrm{H}_{2} \mathrm{O}_{2}$ celular se detectó con la sonda luminiscente AmplexRed ${ }^{\mathrm{TM}}$ (Molecular Probes. Invitrogen) [Quintana-Cabrera et al. 2012; López-Fabuel et al. 2016]. En presencia de la peroxidasa de rábano, la sonda (10-acetil-3,7dihidroxifenoxacina) reacciona estequiométricamente (1:1) con $\mathrm{H}_{2} \mathrm{O}_{2}$, originando resorufina, un compuesto oxidado fluorescente $(\lambda \operatorname{exc} \sim 571 \mathrm{~nm} ; \lambda \mathrm{em} \sim 585 \mathrm{~nm})$, que puede ser detectado por espectrofluorimetría (Figura 10). 
Para la determinación de $\mathrm{H}_{2} \mathrm{O}_{2}$ las neuronas se incubaron con el reactivo AmplexRed ${ }^{\mathrm{TM}}$ $100 \mu \mathrm{M}$ en tampón KRPG (Krebs-Ringer Phosphate Glucose, $\mathrm{NaCl} 145$ mM, Na $\mathrm{PO}_{4}$ $5.7 \mathrm{mM}, \mathrm{KCl} 4.86 \mathrm{mM}, \mathrm{CaCl}_{2} 0.54 \mathrm{mM}, \mathrm{MgSO}_{4} 1.22 \mathrm{mM}$ y D-glucosa $5.5 \mathrm{mM}, \mathrm{pH}$ 7.35) en presencia de peroxidasa de rábano $(0.1 \mathrm{U} / \mathrm{ml})$ durante 1 hora a $37^{\circ} \mathrm{C}$. Cada 20 minutos se anotó la luminiscencia emitida a una longitud de onda de $604 \mathrm{~nm}$, siendo la longitud de excitación de $538 \mathrm{~nm}$, utilizando un espectrofluorímetro Varioskan Flash (Thermo Fischer). Para calcular la velocidad de producción de $\mathrm{H}_{2} \mathrm{O}_{2}$, las pendientes derivadas de la fluorescencia emitida por la sonda se normalizaron con la concentración de proteínas en cada condición [(pmol/h)/ $/ \mathrm{g}$ proteína]. Los resultados se expresaron en unidades arbitrarias $(f o l d)$ respecto a la condición control.
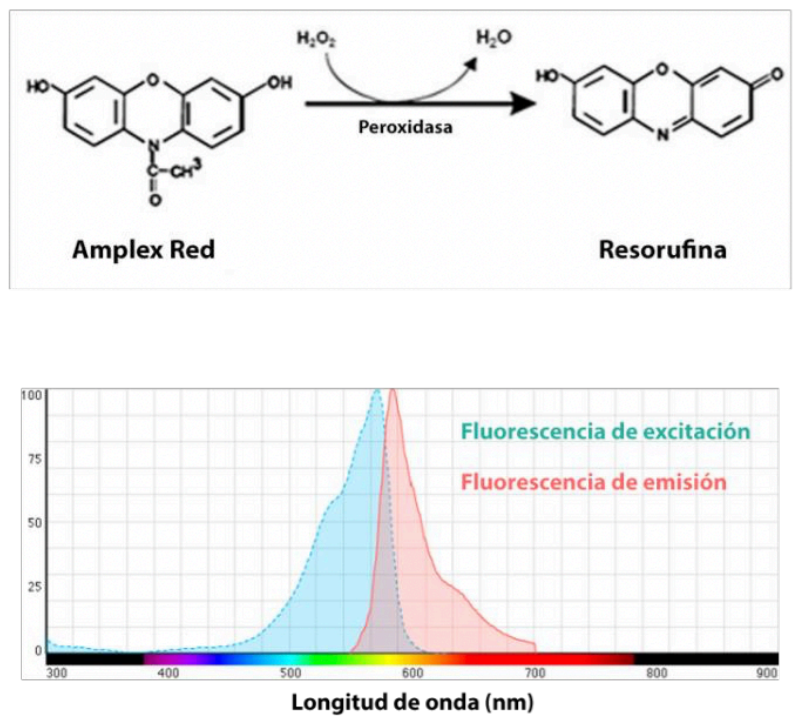

Figura 10. Detección de $\mathrm{H}_{2} \mathrm{O}_{2}$ por AmplexRed ${ }^{\mathrm{TM}}$. La sonda AmplexRed se oxida por $\mathrm{H}_{2} \mathrm{O}_{2}$ en presencia de peroxidasa, dando lugar a resorufina, un compuesto detectable fluorimétricamente.

\subsection{Determinación de anión superóxido}

La producción del anión superóxido $\left(\mathrm{O}^{*}{ }^{*}\right)$ mitocondrial se determinó utilizando la sonda MitoSOX ${ }^{\circledR}$ (Molecular ProbesTM, Invitrogen), que consiste en un derivado catiónico del dihidroetidio unido a un radical trifenilfosfonio [Quintana-Cabrera et al 2012; López-Fabuel et al. 2016]. La sonda es permeable en células vivas y es rápidamente dirigida a la mitocondria debido a su carga positiva, donde puede ser oxidada por $\mathrm{O} 2{ }^{*-}$ y formar 2-hidroxi-5-(trifenilfosfonio) hexiletidio (Figura 11). Este compuesto puede ser detectado de manera específica en el orgánulo ( $\lambda$ exc $\sim 510 \mathrm{~nm}$; $\lambda$ em $\sim 580 \mathrm{~nm}$ ) [Mukhopadhyay et al. 2007]. Para registrar MitoSOX ${ }^{\circledR}$ por citometría de flujo, las células se lavaron con tampón fosfato salino (PBS: $\mathrm{NaCl} 136 \mathrm{mM}$; $\mathrm{KCl}$ 2,7 
$\left.\mathrm{mM} ; \mathrm{Na}_{2} \mathrm{HPO}_{4} \cdot 2 \mathrm{H}_{2} \mathrm{O} 7,8 \mathrm{mM} ; \mathrm{KH}_{2} \mathrm{PO}_{4} 1,7 \mathrm{mM} ; \mathrm{pH} 7,4\right)$ y se incubaron en presencia de MitoSOX ${ }^{\circledR} 2 \mu \mathrm{M}$ en tampón Hank's durante 30 minutos a $37^{\circ} \mathrm{C}$. Posteriormente, las células se tripsinizaron, se centrifugaron ( 5 minutos a $500 \mathrm{x} \mathrm{g}$ ) y se resuspendieron en PBS. En el análisis por citometría se registraron 50.000 eventos para cada triplicado de cada condición. La señal de la sonda MitoSOX ${ }^{\circledR}$ se analizó en el canal FL4 de un citómetro de flujo FACScalibur (BD Biosciences), equipado con un haz láser de argón de $15 \mathrm{~mW}$ sintonizando a $510 \mathrm{~nm}$. Se utilizaron los programas CellQuestTM para adquisición de eventos y Paint-A-GateTM PRO para el análisis de estos (BD Biosciences). Los resultados se expresaron en unidades arbitrarias.

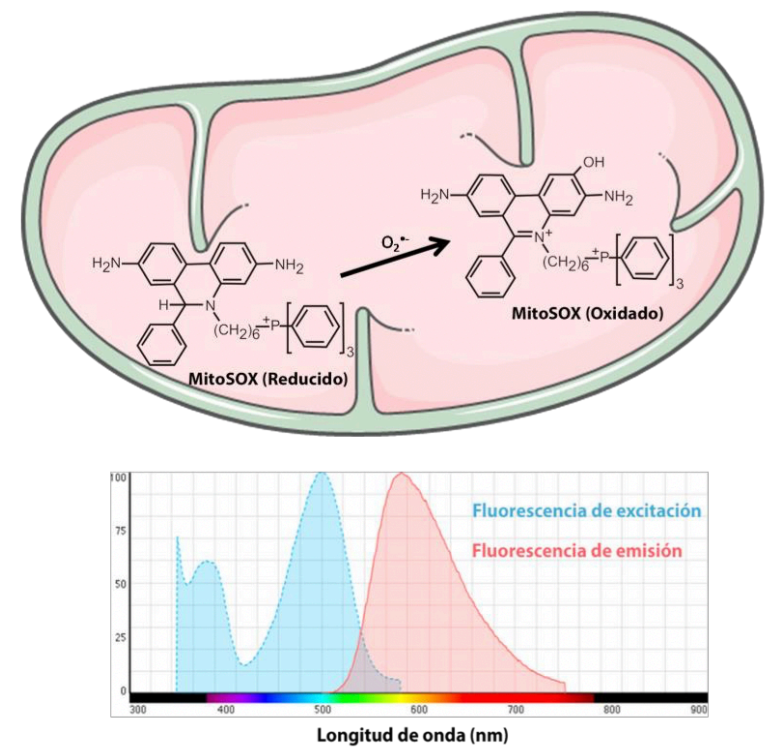

Figura 11. Detección de $\mathbf{O}^{*-}$ por MitoSOX ${ }^{\circledR}$. La oxidación de la sonda MitoSOX ${ }^{\circledR}$ en la mitocondria da lugar a un derivado fluorescente que permite la detección de $\mathrm{O}^{\circ}$ - de manera específica en el orgánulo.

\section{DETERMINACIÓN DEL POTENCIAL DE MEMBRANA}

\section{MITOCONDRIAL}

La evaluación del potencial de membrana $(\Delta \psi \mathrm{m})$ se realizó por citometría de flujo siguiendo las instrucciones del sistema comercial MitoProbe ${ }^{\mathrm{TM}} \mathrm{DilC}_{1}(5)$ (Assay Kit for Flow Citometry; Life Technologies). La sonda $\operatorname{DilC}_{1}(5) \quad\left(1,1^{\prime}, 3,3,3^{\prime}, 3^{\prime}-\right.$ hexametilindolcarbocianina), debido su carácter catiónico, se acumula en las mitocondrias polarizadas, por lo que su pérdida es un índice de despolarización mitocondrial y, por tanto, sirve como indicador de la integridad mitocondrial [GómezSánchez et al, 2011; Veas-Pérez de Tudela et al. 2015]. La intensidad de la tinción con DilC $_{1}(5)$ disminuye cuando las células se someten a condiciones o agentes que alteran 
el potencial mitocondrial, por lo que la intensidad de fluorescencia es directamente proporcional al $\Delta \Psi \mathrm{m}$.

Las células se incubaron en PBS $\left(\mathrm{NaCl} 136 \mathrm{mM}\right.$; $\mathrm{KCl} 2,7 \mathrm{mM} ; \mathrm{Na}_{2} \mathrm{HPO}_{4} \cdot 2 \mathrm{H}_{2} \mathrm{O}$ 7,8 $\mathrm{mM} ; \mathrm{KH}_{2} \mathrm{PO}_{4} 1,7 \mathrm{mM}$; pH 7,4) con la sonda $\mathrm{DilC}_{1}(5) 50 \mathrm{nM}$ durante 30 minutos a $37^{\circ} \mathrm{C}$ en un baño con agitación suave y protegidas de la luz. Tras la incubación, el exceso de sonda fue eliminado por centrifugación a $500 \mathrm{x}$ g durante 5 minutos y se resuspendieron en PBS. En el análisis por citometría se registraron 50.000 eventos para cada triplicado de cada condición. Los valores de $\Delta \Psi \mathrm{m}$ se expresaron como porcentajes. Para establecer el valor basal de $\Delta \Psi \mathrm{m}(0 \%)$ se incubaron las mismas células ya analizadas con el desacoplante mitocondrial cianuro de carbonilo 3-clorofenilhridrazona (CCCP) $10 \mu \mathrm{M}$ durante 15 minutos minutos y se anotó de nuevo el valor de la intensidad de fluorescencia. La señal de la sonda $\operatorname{DilC}_{1}(5)$ se analizó en el canal FL4 del citómetro de flujo FACScalibur (BD Biosciences) equipado con un haz láser de argón de $15 \mathrm{~mW}$ sintonizando a $488 \mathrm{~nm}$. Se utilizaron los programas CellQuestTM para adquisición de eventos y Paint-A- Gate ${ }^{\mathrm{TM}}$ PRO para el análisis de los mismos (BD Biosciences) [Gómez-Sánchez et al, 2011; Veas-Pérez de Tudela et al. 2015].

\section{DETERMINACIÓN DE LA APOPTOSIS NEURONAL}

\subsection{Mediante citometría de flujo}

La muerte celular por apoptosis se determinó mediante citometría de flujo tras teñir las células con anexina V conjugada con DY634 (Immunostep) y 7-amino-actinomicina D (7-AAD) (BD Biosciences). El método se basa en la detección de la fosfatidilserina, un fosfolípido presente en las membranas plasmáticas que en las células apoptóticas se transloca del interior al exterior de la membrana plasmática. La anexina $\mathrm{V}$ es una proteína anticoagulante vascular que posee una gran afinidad por la fosfatidilserina. Por ello, unida a un fluorocromo adecuado, permite la identificación de las células apoptóticas tras su unión a dicho fosfolípido localizado en su superficie celular. Sin embargo, la anexina $\mathrm{V}$ también es capaz de unirse a la fosfatidilserina en el interior de células necróticas que han perdido su integridad de membrana. Para evitar falsos positivos, además de anexina $\mathrm{V}$-APC, se utilizó 7-AAD, un colorante que se une específicamente al DNA de las células necróticas. De este modo, sólo aquellas células inmunorreactivas para la anexina $\mathrm{V}$, que mostraron ser negativas para el 7-AAD, se consideraron apoptóticas [Gómez-Sánchez et al. 2011; Delgado-Esteban et al. 2013]. 
Las neuronas se recolectaron, se resuspendieron en tampón BB (Binding Buffer, Hepes 10mM, $\left.\mathrm{NaCl} 140 \mathrm{mM}, \mathrm{CaCl}_{2} 2,5 \mathrm{mM} ; \mathrm{pH}=7,4\right)$ y se incubaron con Anexina V-DY634 ( $3 \mu 1 / 10^{6}$ células) y 7 -AAD $\left(1 \mu 1 / 10^{6}\right.$ células $)$ durante 15 minutos a temperatura ambiente y en oscuridad. Tras la incubación, se añadió BB suficiente para conseguir una concentración de aproximadamente $10^{6}$ células/ $\mathrm{ml}$.

En el análisis por citometría se registraron 50.000 eventos para cada triplicado de cada condición. Las señales de la anexina V y del 7-AAD se analizaron en los canales FL4 Y FL3, respectivamente, de un citómetro de flujo FACScalibur (BD Biosciences), equipado con un haz láser de argón de $15 \mathrm{~mW}$ sintonizado a $488 \mathrm{~nm}$. Se utilizaron los programas CellQuest ${ }^{\mathrm{TM}}$ para adquisición de eventos y Paint-A-Gate ${ }^{\mathrm{TM}}$ PRO para el análisis de estos (BD Biosciences). Los resultados se expresaron como porcentaje de neuronas apoptóticas (anexina V-APC+/7AAD-) (Figura 12).
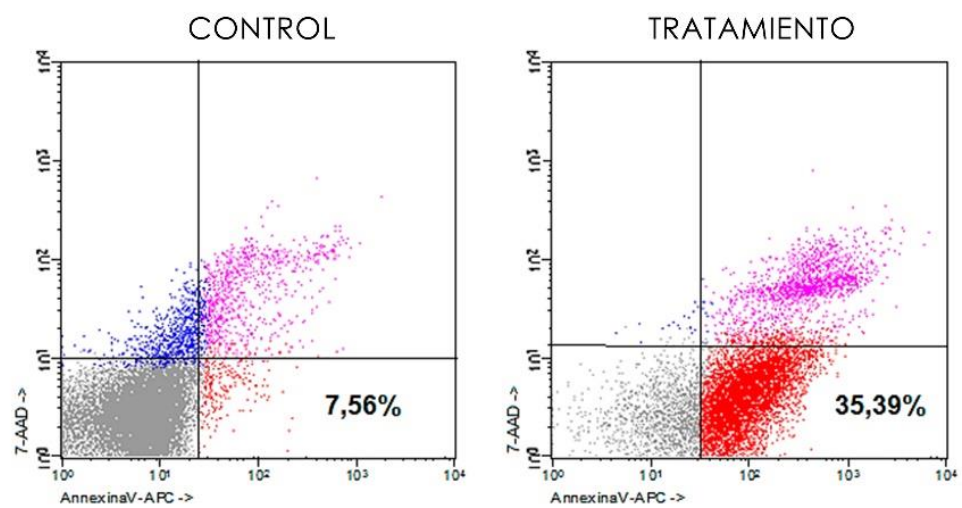

Figura 12. Registros tipo de apoptosis medida por citometria de flujo. Se observa la población de neuronas apoptóticas Anexina +/AAD7- (rojo).

\subsection{Mediante medida de la actividad de la Caspasa-3}

La actividad de la enzima Caspasa-3 se determinó como indicador de apoptosis neuronal. Con este propósito, se empleó el kit comercial Caspase 3 Assay Kit, Fluorimetric (Sigma-Aldrich), según las instrucciones del fabricante. El ensayo se basa en la capacidad de la Caspasa-3 para hidrolizar el péptido sustrato Ac-DEVD-AMC (acetil-Asp-Glu-Val-Asp-7-amino-4-metilcumarina), liberando el motivo fluorescente AMC (7-amino-4-metilcumarina).

Las neuronas se lisaron en tampón de lisis (HEPES $50 \mathrm{mM}$, CHAPS $5 \mathrm{mM}$, DTT 5 mM; pH 7,4) durante 20 minutos en hielo. Seguidamente, se trasvasó el lisado a una placa de 96 pocillos, y se añadió el tampón de ensayo con el sustrato Ac-DEVD-AMC 
(HEPES 20 mM, EDTA 2 mM, CHAPS 0,1\%, DTT 5 mM, Ac-DEVD-AMC $16 \mu \mathrm{M}$, $\mathrm{pH} 7,4)$.

La luminiscencia se registró durante 30 minutos a intervalos de 5 minutos, a $37^{\circ} \mathrm{C}$, utilizando un espectrofluorímetro Varioskan Flash (Thermo Fischer), con una longitud de onda de excitación de $360 \mathrm{~nm}$ y de emisión de $460 \mathrm{~nm}$. Se utilizaron para estos experimentos placas de ELISA de 96 pocillos $\left(\mathrm{Nunc}^{\mathrm{TM}}\right.$ ) y se realizaron, al menos, triplicados por cada condición. Las pendientes obtenidas se utilizaron para el cálculo de la tasa de liberación de AMC. Como recta patrón, se emplearon disoluciones estándar de concentración conocida de AMC. Los resultados se expresaron como $(\mathrm{pmol} / \mathrm{h}) / \mu \mathrm{g}$ proteína.

\section{DETERMINACIÓN DE LA EXPRESIÓN DE PROTEÍNAS MEDIANTE ANÁLISIS DE TRANSFERENCIA TIPO WESTERN BLOT}

\subsection{Extracción de proteínas}

Para obtener extractos de proteínas totales, las células se lavaron con PBS y se lisaron con tampón de lisis RIPA (dodecilsulfato sódico 1\%, EDTA 10 mM, Triton Tx-100 1\% v/v, $\mathrm{NaCl} 150 \mathrm{mM}, \mathrm{Na}_{2} \mathrm{PO}_{4} 10 \mathrm{mM}$; pH 7.0), suplementado con inhibidores de fosfatasas $\left(\mathrm{Na}_{3} \mathrm{VO}_{4} 1 \mathrm{mM}, \mathrm{NaF} 50 \mathrm{mM}\right)$ y proteasas (fluoruro de fenilmetilsulfonilo $100 \mu \mathrm{M}$, aprotinina $50 \mu \mathrm{g} / \mathrm{ml}$, leupeptina $50 \mu \mathrm{g} / \mathrm{ml}$, pepstatina $50 \mu \mathrm{g} / \mathrm{ml}$, anti-papaína $50 \mu \mathrm{g} / \mathrm{ml}$, amastatina $50 \mu \mathrm{g} / \mathrm{ml}$, bestatina $50 \mu \mathrm{g} / \mathrm{ml}$, y el inhibidor de tripsina soybean $10 \mu \mathrm{g} / \mathrm{ml})$. Los extractos se mantuvieron en el hielo 10 minutos y se hirvieron durante 5 minutos. Después de repetir este proceso de nuevo, se centrifugaron a 13,000 x g durante 5 minutos y el sobrenadante se trasladó a un nuevo tubo. Las muestras se conservaron a $-80^{\circ} \mathrm{C}$ hasta su uso.

\subsection{Fraccionamiento subcelular de núcleo y citosol}

Con objeto de aislar las fracciones nucleares y citosólica de las neuronas en diferentes condiciones, se llevó a cabo un protocolo de fraccionamiento diferencial (Figura 13). Se utilizaron preferentemente neuronas sembradas en placas de al menos $60 \mathrm{~cm}^{2}$. Tras lavar las placas con PBS suplementado con $\mathrm{MgCl}_{2} 1 \mathrm{mM}$ a $4^{\circ} \mathrm{C}$ se desprendieron las

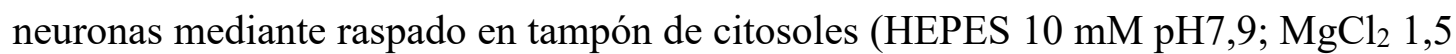
mM, KCl 10 mM, EDTA 1 mM, NP40 0.1\% y sacarosa $300 \mathrm{mM}$ ). La muestra se 
resuspendió con micropipeta y se dejó en hielo al menos 30 minutos (resuspendiendo cada 5 minutos para favorecer el proceso), tiempo tras el cual se comprobó al microscopio de contraste de fases la rotura de las membranas plasmáticas manteniendo los núcleos intactos. La mezcla se centrifugó a $800 \mathrm{x} \mathrm{g} \mathrm{a} 4^{\circ} \mathrm{C}$ durante 10 minutos a fin de separar el contenido citosólico (sobrenadante) en un tubo eppendorf limpio, dónde se hirvió durante 5 minutos. El extracto de proteínas citosólicas se congeló a $-80^{\circ} \mathrm{C}$.

El pellet resultante se resuspendió en tampón de núcleos (HEPES $50 \mathrm{mM}, \mathrm{MgCl}_{2}$ 1,5 $\mathrm{mM}, \mathrm{KCl} 10 \mathrm{mM}$, EDTA $1 \mathrm{mM}$, NP40 1\%) con ayuda de una micropipeta y se mantuvo durante 1 hora en hielo. La suspensión se hirvió durante 5 minutos y se sonicó durante otros 10 minutos con el objetivo de disgregar la envuelta nuclear. La fracción nuclear se mantuvo a $-80^{\circ} \mathrm{C}$ junto con la fracción citosólica hasta su utilización [Veas-Pérez de Tudela et al. 2015].

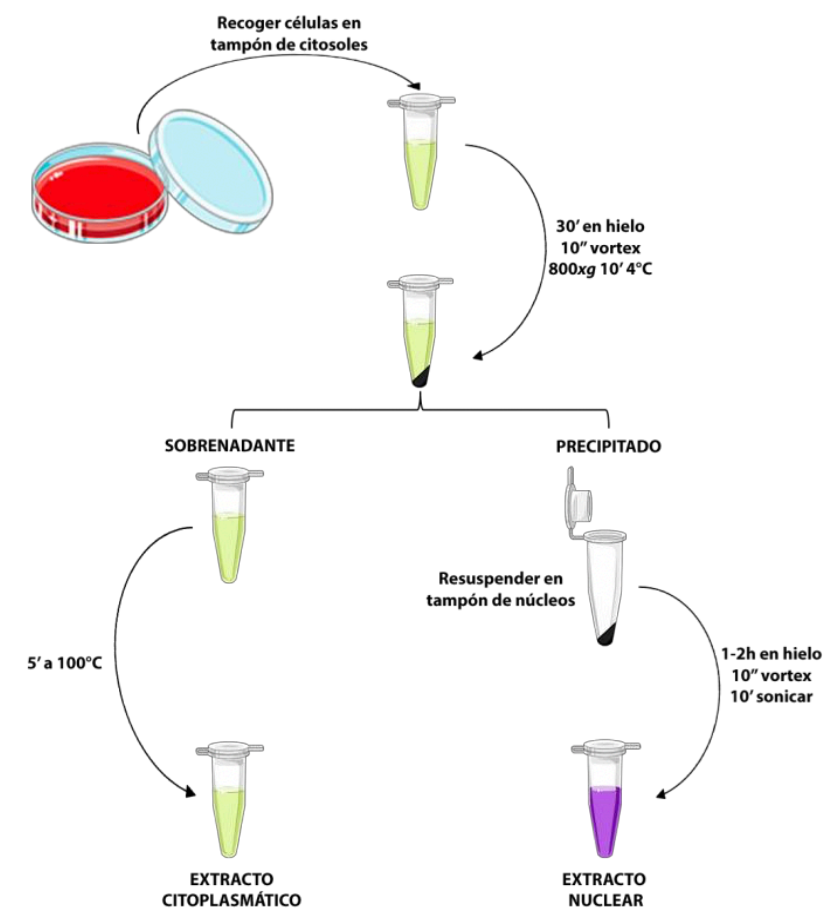

Figura 13. Protocolo de fraccionamiento subcelular. El esquema muestra las diferentes fases del protocolo de fraccionamiento para el aislamiento de los extractos citoplásmatico y nuclear.

\subsection{Fraccionamiento subcelular de mitocondria y citosol}

Para obtener fracciones citosólicas y mitocondriales del cultivo celular, se utilizó un protocolo de centrifugación diferencial [Acin Pérez et al, 2008]. Se utilizaron preferentemente neuronas sembradas en placas de al menos $60 \mathrm{~cm}^{2}$. Las células se 
recogieron por tripsinizacion y se centrifugaron a $600 \mathrm{x} g$ durante 5 minutos. El sedimento se resuspendió en Buffer A (sacarosa 83 mM, MOPS 10 mM; pH 7,2) y se homogeneizó (15 golpes) con una maja de teflón unida a un homogeneizador PotterElvehjem. Después este paso se añadió el mismo volumen de Buffer B (sacarosa 250 $\mathrm{mM}$, MOPS $30 \mathrm{mM}$; pH 7,2), se centrifugó a 1.000 x g durante 5 minutos para eliminar núcleos y células no rotas y el sobrenadante se centrifugó a 1.2000 x g durante 2 minutos. Después de este paso se lavó una vez con Buffer C (sacarosa 320 mM, EDTA $1 \mathrm{mM}$, Tris-HCI $10 \mathrm{mM}$; pH 7,4) y se volvió a centrifugar en las mismas condiciones. Las mitocondrias se resuspendieron en Buffer D (acido 6-aminohexanoico 1M, BisTris-HCI $50 \mathrm{mM}$ ), se incubaron en hielo durante 5 minutos, se centrifugó el sobrenadante a $1.3000 \mathrm{~g}$ durante 30 minutos, se recoge el sobrenadante que contenía la fracción citosólica, en un eppendrof nuevo, se resuspendió El sedimento mitocondrial en tampón RIPA, se mantuvo a $-80^{\circ} \mathrm{C}$.

\subsection{Determinación de la concentración de proteínas}

La concentración de los extractos proteicos se midió mediante el ensayo del ácido bicinconínico (BCA; Pierce ${ }^{\mathrm{TM}}$, Thermo Fisher Scientific). Este método colorimétrico se basa en la reducción del $\mathrm{Cu}^{2+}$ (azul) a $\mathrm{Cu}^{+}$en presencia de proteínas y en medio alcalino. El catión $\mathrm{Cu}^{+}$generado reacciona con el BCA originando un producto de color morado que absorbe de manera lineal a $562 \mathrm{~nm}$. La absorbancia se midió espectrofotométricamente en el lector de placas Multiskan Ascent (Thermo Fischer). Se utilizó la albúmina sérica bovina (BSA) como estándar para el cálculo de la recta patrón. Todas las determinaciones se realizaron por triplicado.

\subsection{Electroforesis de proteínas en SDS-Page}

Los extractos celulares se sometieron a electroforesis en condiciones desnaturalizantes (SDS-PAGE: electroforesis de poliacrilamida en presencia de dodecilsulfato sódico) para poder estudiar su composición proteica.

Se utilizaron geles discontinuos que presentan (i) en la parte superior un gel concentrador de la banda o "stacking" con un porcentaje constante de acrilamida (acrilamida:bisacrilamida 29:1 (Bio-Rad Laboratories) al 3\% en Tris-HCl $1 \mathrm{M} \mathrm{pH} \mathrm{6,8}$ con SDS 10\%; persulfato amónico (PSA) 10\%; TEMED ( $N, N, N, N^{\prime}-$ tetrametilendiamina $0,1 \%$ ) y (ii) en la parte inferior un gel separador o "running" en el 
que tiene lugar la separación de los componentes y que presenta distintos porcentajes de acrilamida en función del rango de separación de pesos moleculares deseado (acrilamida:bisacrilamida 29:1 al 8, 10, 12 ó 15\% en Tris- $\mathrm{HCl}$ 1,5 M pH 8,8 con SDS 10\%, PSA $10 \%$ y TEMED 0,08\%). El extracto proteico, de 20 a $50 \mu \mathrm{g}$, se resuspendió en tampón de carga ( $\beta$-mercaptoetanol 4\% (v/v), SDS 8\% (p/v), azul de bromofenol $0.02 \%(\mathrm{p} / \mathrm{v})$, glicerol $4 \%(\mathrm{v} / \mathrm{v})$ y Tris-base $250 \mathrm{mM})$ en un volumen correspondiente a la cuarta parte del volumen final. Las muestras se hirvieron durante 5 minutos a $100^{\circ} \mathrm{C}$, y se centrifugaron a $13.000 \mathrm{x}$ g durante 5 minutos a $4^{\circ} \mathrm{C}$. Para identificar los pesos moleculares de las proteínas en estudio se utilizó un marcador de peso molecular (Page Ruler $^{T M}$ Plus Prestained Protein Ladder, ThermoScientific) que se cargó en el gel junto a las muestras.

Las proteínas se separaron utilizando un sistema de electroforesis vertical (MiniProtean- $3^{\circledR}$, Bio-Rad) y tampón de electroforesis (Tris $25 \mathrm{mM}$, glicina $200 \mathrm{mM}$ y SDS al 0,1\% (p/v); pH 8,3). Una vez finalizada la electroforesis, los geles se sometieron a electrotransferencia e inmunodetección mediante la técnica de Western Blot.

\subsection{Inmunodetección de proteínas por Western Blot}

Las proteínas previamente separadas en geles SDS-PAGE se transfirieron electroforéticamente a membranas de nitrocelulosa (Hybond ${ }^{\circledR}$, Amersham Biosciences) $^{-1}$ utilizando el sistema Mini-Transblot (Bio- Rad) y tampón de transferencia (Tris 25 $\mathrm{mM}$, glicina $192 \mathrm{mM}$ y metanol al 20\% (v/v); pH 8,3). Con el objetivo de evitar las uniones inespecíficas de anticuerpos, se bloquearon las membranas durante 1 hora con leche desnatada (Sveltesse, Nestle) al 5\% (p/v) en TTBS (Tris 20 mM, NaCl 500 mM, Tween-20 al 0,1\% (v/v); pH 7,5) a temperatura ambiente. A continuación, se incubaron las membranas a $4^{\circ} \mathrm{C}$ durante toda la noche en una solución de BSA o leche al $2 \%(\mathrm{p} / \mathrm{v})$ en TTBS que contiene el anticuerpo primario deseado (Tabla 1). Como control de carga se utilizó anti-GAPDH (gliceraldheído 3-fosfato deshidrogenasa para extractos totales, proteína ribosomal S6 para la fracción citosólica, VDAC para la mitocondrial y Lámina B para la fracción nuclear. Al día siguiente las membranas se lavaron 3 veces durante 5 minutos con TTBS para retirar el exceso de anticuerpo primario y seguidamente se incubaron con el anticuerpo secundario correspondiente, conjugado con la peroxidasa de rábano, en TTBS con leche al $2 \%(\mathrm{p} / \mathrm{v})$ durante una hora a temperatura ambiente. Tras 3 lavados en TTBS se realizó un último lavado en TBS (TTBS sin Tween-20), 
para evitar que el Tween interfiera con algunos reveladores. Por último, según la proteína a detectar, se incubaron las membranas con los reactivos de quimioluminiscencia Super Signal ${ }^{T M}$ West Dura Extended Duration Substrate (Thermo Scientific), Western Blottin Luminol Reagent (Santa Cruz Biotechnology) o Pierce ${ }^{T M}$ ECL Plus Western Blotting Substrate (Thermo Scientific), siguiendo las instrucciones de los fabricantes. Finalmente, las membranas se expusieron a una película de autoradiografía (Fuji Medical X-Ray Film, Fujifilm) para detectar la señal.

Se realizaron triplicados biológicamente independientes de cada experimento. Las cuantificaciones se llevaron a cabo con el software ImageJ (ImageJ 1.48v; Java 1.6.0_65 [64-bit]), normalizando cada condición con su control de carga. Los resultados se expresaron en unidades arbitrarias de cantidad de proteína respecto a la condición control de cada experimento.

Tabla 1. Anticuerpos utilizados en los estudios de expresión proteica por transferencia tipo western.

\begin{tabular}{|c|c|c|c|c|}
\hline Anticuerpo (Ac) & Especie & Dilución & Referencia & Casa comercial \\
\hline \multicolumn{5}{|l|}{ Ac. Primarios } \\
\hline MAP2 & Ratón & $1 / 500$ & ab11268 & Abcam \\
\hline \multirow[t]{2}{*}{ BASOON } & Conejo & $1 / 1000$ & 141003 & Synaptic \\
\hline & & & & Systems \\
\hline SYP & Ratón & $1 / 2000$ & Sc- 17750 & Santa Cruz \\
\hline \multirow[t]{2}{*}{ PSD-95 } & Ratón & $1 / 500$ & MA1-046 & Thermo \\
\hline & & & & Scientific \\
\hline TUJ 1 & Conejo & $1 / 2000$ & ab18207 & Abcam \\
\hline \multirow[t]{2}{*}{ HA } & Ratón & $1 / 10,000$ & 26183 & Thermo \\
\hline & & & & Scientific \\
\hline \multirow[t]{2}{*}{ CATALASA } & Conejo & $1 / 1000$ & PA5-23246 & Thermo \\
\hline & & & & Scientific \\
\hline VDAC & Conejo & $1 / 500$ & PC548 & Calbiochem \\
\hline \multirow[t]{2}{*}{ S6 } & Conejo & $1 / 1000$ & 9202 & Cell Signaling \\
\hline & & & & Technology \\
\hline
\end{tabular}




\begin{tabular}{lllll}
\hline GAPDH & Ratón & $1 / 10.000$ & 4300 & Ambion
\end{tabular}

Ac. secundario

\begin{tabular}{lllll} 
Anti-ratón & Cabra & $1 / 10.000$ & $170-6516$ & BioRad \\
Anti-Conejo & Cabra & $1 / 10.000$ & Sc-2030 & Santa Cruz \\
\hline
\end{tabular}

\section{7 "Stripping" de membranas de nitrocelulosa}

La técnica de "stripping" o lavado permite reutilizar las membranas de nitrocelulosa para incubarlas de nuevo con un anticuerpo primario distinto al inicial y poder así inmunodetectar otras proteínas. Para ello, se incubaron las membranas en el tampón Restore Western Blot Stripping Buffer (Thermo Scientific) durante 10 minutos. Posteriormente, se lavaron 3 veces con TTBS a temperatura ambiente y se bloqueó de nuevo con leche al 5\% (p/v). Para la incubación de los anticuerpos y el revelado se procede como se ha detallado en la sección anterior.

\section{OBTENCIÓN Y MANIPULACIÓN DEL RNA}

\subsection{Extracción del RNA total}

La extracción de RNA se llevó a cabo con el kit comercial Genelute ${ }^{\mathrm{TM}}$ Mammalian Total RNA Kit (Sigma) según las instrucciones del fabricante.

A los 9 días de cultivo, las neuronas se lisaron con una mezcla de ßmercaptoetanol:solución de lisis (Lysis Solution, Sigma-Aldrich) en proporción 1:100 (v/v). Con el objeto de evitar la degradación del RNA de las muestras, los raspadores se trataron con solución RNase away (Sigma) y agua DEPC (di-etil piro-carbonato) previo al raspado de las placas. Los lisados se purificaron por medio de un protocolo basado en columnas de afinidad de sílice y elución en agua libre de nucleasas con el fin de obtener el RNA total de los extractos celulares. Para eliminar la posible contaminación con DNA genómico la muestra se trató con 100 U de DNasa I (DNase I, RNase-free, Roche) en un tampón Tris- $\mathrm{HCl} 400$ mM, NaCl 100 mM, MgCl 60 mM y $\mathrm{CaCl}_{2} 10 \mathrm{mM} ; \mathrm{pH}$ 7,9 durante 15 minutos a temperatura ambiente.

Se midió la concentración del RNA purificado con un espectrofotómetro UV-Vis Nanodrop 2000 (Thermo Fisher). El ratio de absorbancia de 260 frente a $280 \mathrm{~nm}$ (A260 
/ A280), que determina la pureza del RNA, fue de 1,8 - 2. La elución de RNA se congeló a $-80^{\circ} \mathrm{C}$ hasta su uso.

\subsection{Reacción en cadena de la polimerasa a tiempo real}

Mediante esta técnica analizamos la expresión diferencial de genes que cuantificamos de forma relativa respecto a un control interno de expresión constante (housekeeping). En la PCR a tiempo real los procesos de amplificación y detección se producen de manera simultánea, gracias a la emisión de fluorescencia por parte de un fluorocromo (SYBR Green), que se intercala entre las hebras de DNA bicatenario, de modo que la fluorescencia es proporcional a la cantidad de producto de PCR amplificado (amplicón).

Antes de analizar la expresión de los diferentes genes, se puso a punto la concentración de cada oligonucleótido empleado como cebador (primer) y se calcularon las eficiencias de amplificación de los primers diseñados con los programas Geneious (Versión pro-Trial, Biomatters Limited) y Amplifix (Universidad de Marsella). Se consideraron óptimas las eficiencias comprendidas entre el 85 y el 115\% (Guide to Performing Relative Quantitation of Gene Expression Using Real-Time Quantitative $P C R$, AppliedBiosystems). La obtención de las eficiencias de cada primer es necesaria para poder comparar la expresión de los diferentes genes mediante el Método Comparativo de $\mathrm{Ct}(\Delta \Delta \mathrm{Ct})$.

Para la cuantificación de expresión de los genes de estudio, se utilizó el kit comercial Power SYBR ${ }^{\circledR}$ Green RNA-to-Ct $t^{\mathrm{TM}}$ 1-Step Kit (Applied Biosystems), que permite acoplar la retrotranscripción y la amplificación en un único paso. Se partió de $100 \mathrm{ng}$ de RNA y el volumen final por reacción fue de $20 \mu$ l. Todas las reacciones se realizaron por triplicado utilizando el termociclador Mastercycler®ep Realplex (Eppendorf).

El perfil de cada reacción fue el siguiente: un ciclo de 30 minutos a $48^{\circ} \mathrm{C}$ (etapa de retrotranscripción), un ciclo de 10 minutos a $95^{\circ} \mathrm{C}$ (activación de la enzima DNA polimerasa), 40 ciclos de 15 segundos a $95^{\circ} \mathrm{C}$ (desnaturalización) y 1 minuto a $60^{\circ} \mathrm{C}$ (anillamiento y elongación) (Figura 14). 


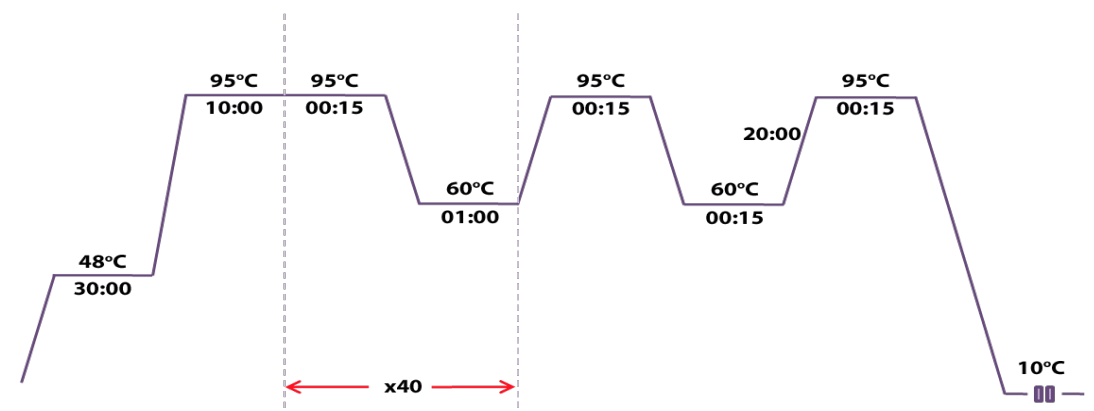

Figura 14. Esquema de rt-qPCR. Perfil de la reacción de rt-qPCR donde se especifica la temperatura, tiempo y número de ciclos de cada etapa.

El valor que se obtuvo por cada reacción fue el $\mathrm{C}_{\mathrm{t}}$ (threshold cycle, ciclo umbral) o ciclo en el que la fluorescencia emitida por el SYBR Green es detectable dentro de la fase lineal. Se obtiene así el $\mathrm{C}_{\mathrm{t}}$ para cada uno de los genes de estudio y para el housekeeping (Gapdh). El incremento de $C_{t}\left(\Delta C_{t}\right)$ es la diferencia entre el $C_{t}$ de cada gen y el $\mathrm{C}_{\mathrm{t}}$ de Gapdh.

El Método Comparativo de $\mathrm{C}_{\mathrm{t}}$ relaciona el número de copias entre las distintas condiciones, que se obtiene al final de una reacción optimizada empleando la fórmula [Bustin et al. 2009]:

$$
\begin{gathered}
2^{-\Delta \Delta \mathrm{Ct}} \\
2-[(\text { Ctmuestra }-\mathrm{CtGapdh})-(\text { Ctcalibrador }-\mathrm{CtGapdh}]
\end{gathered}
$$

Consideramos como calibrador la condición sobre la que se compara la expresión y sobre la que se relativiza los resultados dándole el valor de 1 . Niveles de expresión igual a 1 indican que la muestra problema presenta la misma expresión de un determinado gen que el control. Niveles $>1$ indican que hay un incremento de expresión con respecto al control, y niveles $<1$ indican que la expresión disminuye con respecto al control.

Los resultados se mostraron en unidades arbitrarias de expresión, fold o número de veces de expresión entre la muestra problema y un calibrador o control.

\section{INMUNOCITOQUÍMICA E IMAGEN}

Para los ensayos de inmunocitoquímica, las neuronas se cultivaron sobre cubreobjetos de cristal previamente esterilizados a fuego y tratados con una solución de poli-Lornitina $15 \mu \mathrm{g} / \mathrm{ml}$ (Sigma) y fibronectina $1 \mu \mathrm{g} / \mathrm{ml}$ (Sigma).

A los 8 días de cultivo y tras los tratamientos pertinentes, las neuronas se lavaron con 
PBS y se fijaron con paraformaldehído al 4\% (v/v) en PBS durante 20 minutos. Posteriormente, se incubaron con glicina $0,1 \mathrm{M}$ en PBS durante 20 minutos y se permeabilizaron con Triton X-100 al $0,25 \%(\mathrm{v} / \mathrm{v})$ en PBS durante 5 minutos. A continuación, se incubaron en la solución de bloqueo (Triton X-100 al 0,1\% (v/v) y suero de cabra al 10\% (v/v) en PBS) a temperatura ambiente durante 1 hora. Se prepararon las mezclas de los anticuerpos (Tabla 2) en la solución de incubación (suero de cabra al 5\% en PBS) y se mantuvieron con las muestras toda la noche a $4^{\circ} \mathrm{C}$ en agitación suave. Al día siguiente se lavaron con PBS y se incubaron con los anticuerpos secundarios conjugados con los fluoróforos Cy2, Cy3 a una dilución 1/500 (Jackson Immuno Research) en solución de incubación, durante 1 hora a temperatura ambiente, en oscuridad y en agitación suave. Finalmente, se retiró el exceso de anticuerpo mediante lavados de PBS y se incubaron 10 minutos con los marcadores nucleares DAPI $30 \mu \mathrm{M}$ (Sigma) o TO-PRO ${ }^{\circledR}-330 \mu \mathrm{M}$ (Molecular Probes).

Tabla 2. Anticuerpos y sondas nucleares utilizados en inmunocitoquímica

\begin{tabular}{lllll}
\hline Anticuerpo (Ac) & Especie & Dilución & Referencia & Casa comercial \\
\hline Ac. primarios & & & & \\
MAP 2 & Conejo & $1 / 500$ & ab32454 & Abcam \\
MAP2 & Ratón & $1 / 500$ & ab11268 & Abcam \\
\hline BASOON & Conejo & $1 / 500$ & 141003 & Synaptic Systems \\
CASPASA-3 & Conejo & $1 / 500$ & 9661 & Cell \\
\hline HA & & & & Technology \\
\hline MTCO-1 & Conejo & $1 / 200$ & 3724 & Cell \\
\hline SDHA & & & & Signaling \\
\hline Ac. secundarios & Ratón & $1 / 1000$ & ab14705 & Abcam \\
\hline Cy2 & Ratón & $1 / 1000$ & ab14715 & Abcam \\
\hline Cy2 & Ratón & $1 / 500$ & 115.225 .003 & Jackson \\
\hline Cy3 & Conejo & $1 / 500$ & 111.225 .003 & Jackson \\
\hline
\end{tabular}




\begin{tabular}{lllll}
\hline Cy3 Conejo & $1 / 500$ & 111.175 .003 & Jackson
\end{tabular}

Sondas nucleares

$\begin{array}{lccl}\text { DAPI } & 30 \mu \mathrm{M} & \text { D\#9542 } & \text { Sigma } \\ \text { TO-PRO-3 } & 30 \mu \mathrm{M} & \text { T3605 } & \text { Mol Probes }\end{array}$

Los cubreobjetos se lavaron de nuevo con PBS, tras lo cual se montaron sobre portaobjetos utilizando el reactivo Slow Fade Antifade ${ }^{\circledR}$ (Molecular Probes) para evitar la pérdida de fluorescencia. La visualización y adquisición de microfotografías confocales se llevó a cabo utilizando un microscopio Leica TSC-SL (Leica Microsystems) y un Spinning disk Roper Scientific con microscopio Olympus IX81 $\left(\right.$ Olympus $^{\circledR}$ ). Se utilizó además un microscopio invertido de epifluorescencia Nikon Eclipse Ti- E (Nikon). Las imágenes se procesaron con el software ImageJ (ImageJ $1.48 \mathrm{v}$; Java 1.6.0_65 [64-bit]).

\section{MODELO EXPERIMENTAL DE ISQUEMIA CEREBRAL IN VIVO}

El modelo de isquemia-reperfusión cerebral de elección fue el de oclusión intraluminal transitoria de la arteria cerebral media (tMCAO). Este procedimiento quirúrgico, desarrollado por Koizumi [Koizumi et al. 1986] y modificado por Longa [Longa et al., 1989], consiste en la inserción intraluminal de un filamento hasta el origen de la arteria cerebral media (ACM). El filamento se retira tras el tiempo deseado, provocando así una isquemia transitoria $(\mathrm{t})$ en el territorio de la arteria cerebral media seguido por la restauración de la circulación sanguínea [Rodriguez et al, 2018, 2437].

En pacientes de ictus isquémico, la arteria cerebral media está comúnmente afectada, extendiéndose el daño en el tejido desde la región del estriado hasta la corteza. Es por ello que este modelo es el más ampliamente utilizado en investigación preclínica. Además, la inducción de la reperfusión mediante esta técnica es similar a la del uso de fármacos trombolíticos o trombectomía mecánica en la práctica clínica [Shahjouei et al. 2016]

En este procedimiento, se utilizaron ratones macho wt y mCAT de 3-4 meses. Estos se anestesiaron con sevoflurano al $2,5 \%$ en una mezcla de oxígeno $(30 \%)$ y nitrógeno (70\%) mediante una máscara facial. Durante todo el procedimiento, se monitorizó la 
temperatura del animal a través de una sonda rectal con el fin de mantener una temperatura constante durante todo el proceso $\left(36-37^{\circ} \mathrm{C}\right)$, para lo que se utilizó una fuente de calor externa. En primer lugar, tras colocar al animal en posición prona se realizó una incisión vertical de $0,5 \mathrm{~cm}$ en la piel en la línea media de la cabeza, exponiendo el cráneo subyacente. Para monitorizar el flujo sanguíneo cerebral en la región de la ACM que sería ocluida, se fijó en el cráneo $(1 \mathrm{~mm}$ posterior y $5 \mathrm{~mm}$ lateral a bregma) un filamento de fibra óptica conectado a un monitor Láser-Doppler Moor $V M S-L D F$ (Moor Instruments).

A continuación, se colocó el animal en posición supina y se realizó una incisión vertical de $1 \mathrm{~cm}$ entre el manubrio del esternón y la mandíbula. Tras disecar las estructuras subyacentes, se aisló la arteria carótida común (ACC) y se anudó con un lazo de sutura temporal, posteriormente se disecó la arteria carótida externa (ACE) y se anudó lo más lejos posible de la ramificación con la común. Para evitar sangrados, se cauterizaron ramificaciones de la carótida externa, como la arteria occipital y la superior tiroidea. La arteria carótida interna (ACI) se ligó temporalmente mediante un lazo de sutura, tras lo que se realizó un corte parcial con microtijeras en la ACE, por donde se introdujo un monofilamento de nylon recubierto de silicona (Doccol Corporation). Con ayuda de unos fórceps el filamento fue conducido cuidadosamente por el interior de la ACI hacia la ACM, hasta que el avance del filamento ofrece una ligera resistencia (Figura 15). En ese punto se comprobó que el flujo sanguíneo descendía un $80 \%$ aproximadamente respecto al flujo basal. Tras 30 minutos de isquemia se retiró el filamento y las ligaduras temporales permitiendo la reperfusión, que fue monitorizada mediante Laser-Doppler. Se procedió entonces a suturar las incisions realizadas.

Para compensar la pérdida de fluidos durante el procedimiento se administró $0,5 \mathrm{ml}$ de suero salino atemperado. Como analgésico se administró buprenorfina $0,05 \mathrm{mg} / \mathrm{kg}$ por vía subcutánea, inmediatamente antes de comenzar el procedimiento, a las 6 horas tras finalizar y cada 12 horas durante los dos primeros días. Los animales se sacrificaron tras un periodo de reperfusión de 24 horas posterior a la oclusión. 


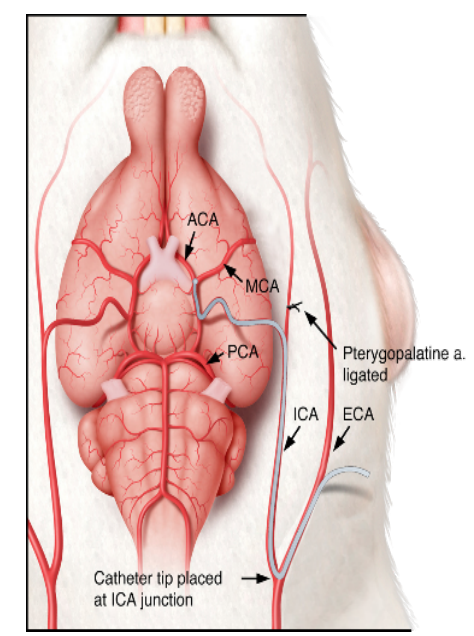

Figura 15. Esquema de la isquemia focal in vivo. Se especifican las arterias de la zona de la oclusión y el recorrido del filamento hasta la arteria cerebral media. ACA, arteria cerebral anterior; ECA, arteria carótida externa; ICA, arteria carótida interna; MCA, arteria cerebral media; PCA, arteria cerebral.

\subsection{Medida del volumen de infarto}

Para comprobar el volumen de infarto después del procedimiento de isquemia experimental, se realizó tinción con cloruro de 2,3,5-trifeniltetrazolio, conocido también como cloruro de tetrazolio o TTC. El TTC es un indicador redox usado para diferenciar entre tejidos metabólicamente activos (color rojizo) e inactivos (color blanco), dependiendo de si se produce o no la reducción enzimática de TTC (incoloro) a TPF (1,3,5-tripfenilformazan; rojo) catalizada por deshidrogenasas que se encuentran principalmente en la mitocondria. Los animales se sacrificaron por dislocación cervical. A continuación, se extrajo el cerebro rápidamente y se cortó en frío en rodajas de $1 \mathrm{~mm}$ con ayuda de una matriz coronal. Las rodajas se incubaron con 2\% TTC en solución salina durante 10 minutos a temperatura ambiente. Los volúmenes de infarto se determinaron a partir de fotografías de las secciones cerebrales. Las imágenes fueron analizadas utilizando el programa de procesamiento de imágenes ImageJ (ImageJ 1.48v; Java 1.6.0_65 [64-bit]). 


\section{INMUNOHISTOQUÍMICA}

\subsection{Obtención de muestras de tejido}

Los ratones (wt, mCAT) se anestesiaron mediante inyección intraperitoneal de una mezcla (1:4) de clorhidrato de xilacina (Rompun; Bayer) y ketamina (Imalgene; Merial), usando $1 \mathrm{~mL}$ de la mezcla por kg de peso. Luego se perfundieron vía aorta con una solución de $\mathrm{NaCl}$ al $0.9 \%$, seguido de $5 \mathrm{~mL}$ por gramo de peso del fijador Somogyi (4\% (p/v) paraformaldehido, $0,2 \%(\mathrm{p} / \mathrm{v})$ ácido pícrico en buffer fosfato $0,1 \mathrm{M} ; \mathrm{pH} 7,4)$. Una vez perfundidos, los cerebros se extrajeron cuidadosamente para obtener tres secciones coronales que se fijaron en solución de Somogyi durante toda la noche a $4^{\circ} \mathrm{C}$. Los bloques de cerebro se lavaron sucesivamente durante $10 \mathrm{~min}, 30 \mathrm{~min}$ y 2 horas con una solución de buffer fosfato (PB 0,1M; $\mathrm{pH} 7,4)$, y se sumergieron secuencialmente en una solución de sacarosa en PBS al 10\%, 20\% y 30\% (p/v). Tras la crioprotección del tejido se obtuvieron secciones coronales de $20 \mu \mathrm{m}$ de espesor mediante un criostato (Leica CM 1950 AgProtect, Leica).

\subsection{Inmunofluorescencia}

Las secciones coronales se lavaron tres veces en PB 0,1 M durante 10 minutos cada vez, y posteriormente se incubaron en (i) anti-NeuN 1:1000 (MAB377, Millipore), o anti- $\gamma \mathrm{H} 2 \mathrm{AX}$ 1:500 (05-636, Millipore) en Triton X-100 al 0,2\% (Sigma) y suero de cabra al 5\% (Jackson Immoresearch) durante $72 \mathrm{~h}$ a $4^{\circ} \mathrm{C}$ en PB 0,1 M; (ii) anticuerpos secundarios conjugados con fluoróforo (Jackson Immunoresearch Laboratories) en Triton X-100 al 0,05\% y suero de cabra al 2\% en 0,1 M PBS, durante $2 \mathrm{~h}$ a temperatura ambiente; (iii) los núcleos se tiñeron con 4,6-diamino-2-fenilindol 0,5 $\mu \mathrm{g} / \mathrm{mL}$ (DAPI, Sigma D9542) durante 10 minutos a temperatura ambiente [Rodriguez et al 2017]. Después de lavar con PBS, las secciones se montaron con el medio acuoso Fluoromount $^{\mathrm{TM}}$ (Sigma).

Las preparaciones se examinaron mediante microscopía de epifluorescencia empleando conjuntos de filtros apropiados de un microscopio (Nikon Invertided microscope Eclipse Ti-E, Japan) equipado con un iluminador de fibra precentrado (Nikon Intensilight C-HGFI) y una cámara digital B/N CCD (Hamamatsu, ORCAER), o mediante un microscopio confocal espectral (Leica TSC-SL, Leica Microsystems) con tres láseres: multiline Argon (488 nm), Helium-Neon (543 nm) y Helium-Neon (633 
nm); y equipado con objetivos 40X y 63X (1.4) HCX PL Apo en aceite de inmersión para imágenes de alta resolución. Las cuantificaciones se realizaron por triplicado, en tres regiones de corteza o estriado de tres secciones consecutivas, con cada animal wt y mCAT, a partir de imágenes de epifluorescencia. Se contó el número de células totales y neuronas de cada región utilizando tinción de DAPI y NeuN, respectivamente, utilizando el programa de procesamiento de imágenes ImageJ (ImageJ 1.48v; Java 1.6.0_65 [64-bit]).

\subsection{Estudio de la apoptosis mediante la técnica de TUNEL}

La técnica TUNEL (Terminal deoxynucleotidyl transferase dUTP nick end-labelling) se realizó en secciones cerebrales siguiendo el protocolo del fabricante (Roche Diagnostics). Las secciones de cerebros fijadas, se preincubaron en buffer de TUNEL que contiene $\mathrm{CoCl}_{2} 1 \mathrm{mM}$, cacodilato de sodio $140 \mathrm{mM}$ y $0,3 \%$ de triton X-100 en Tris buffer $30 \mathrm{mM}, \mathrm{pH} 7,2$, durante 30 minutos. Después de la incubación a $37^{\circ} \mathrm{C}$ con la mezcla de reacción TUNEL que contiene el enzima desoxinucleotidil transferasa terminal $(800 \mathrm{U} / \mathrm{mL})$ y la mezcla de nucleótidos (dUTPs $1 \mathrm{mM}$ ) durante 90 minutos, se lavaron los cortes de cerebro con PBS y se realizó una tinción con estreptavidina unida al fluoróforo Cy3 (Jackson Immunoresearch Laboratories) [Rodriguez et al, 2017].

\section{TRATAMIENTO ESTADÍSTICO DE LOS RESULTADOS}

Todas las determinaciones en neuronas en cultivo se realizaron, al menos, en tres réplicas biológicas. Los valores se expresaron como medias \pm S.E.M. (error estándar de la media) de, al menos, tres experimentos independientes. La significatividad se determinó mediante análisis de la varianza (ANOVA), seguido del test de Bonferroni (para comparaciones múltiples) o el test de la $t$ de Student (para comparaciones entre dos únicos grupos de valores). En todos los casos, un valor de $\mathrm{p}<0,05$ se consideró estadísticamente significativo. El análisis estadístico se realizó con ayuda del software

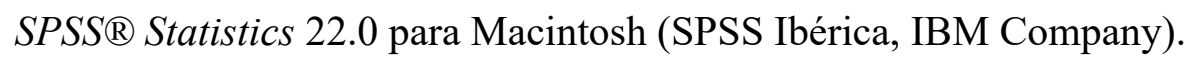




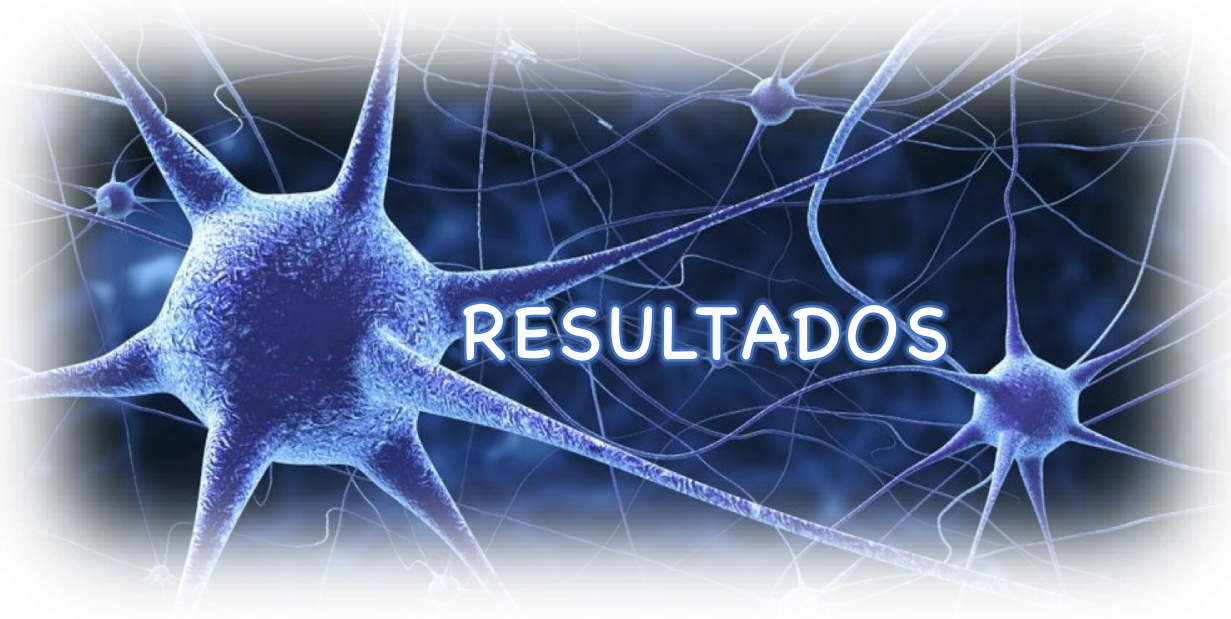




\section{CARACTERIZACIÓN DEL MODELO MCAT EN CULTIVO PRIMARIO DE NEURONAS}

\subsection{Las neuronas mCAT expresan catalasa en la mitocondria}

El estrés oxidativo está muy vinculado con la fisiopatología del ictus isquémico. Aunque su efecto neurotóxico es bien conocido, en contra de lo observado en los modelos preclínicos, las terapias antioxidantes empleadas hasta el momento no han logrado la eficacia esperada en la práctica clínica. Por ello, es necesario el estudio de la función neuroprotectora de los mecanismos antioxidantes en la isquemia cerebral para la identificación de potenciales dianas terapéuticas y el desarrollo de nuevas estrategias terapéuticas en ictus. Debido al papel fundamental de la mitocondria en la generación de especies reactivas de oxígeno (ROS) [Bolaños et al, 2009], en el presente trabajo generamos, mediante un abordaje genético, un nuevo modelo animal que expresa la enzima catalasa en la mitocondria de manera constitutiva [Vicente-Gutiérrez et al. 2019]. Así, se pretenden reducir los niveles endógenos de ROS, aprovechando la capacidad antioxidante de la catalasa, que cataliza la descomposición de peróxido de hidrógeno $\left(\mathrm{H}_{2} \mathrm{O}_{2}\right)$ en oxígeno molecular y agua (Figura16).

Figura 16. Estrategia mCAT (esquema de mitocondria y reacción de catalasa...)

Tal y como se describe en el apartado de Material y Métodos, la expresión mitocondrial de la catalasa (mCAT) se consiguió insertando, aguas arriba, la secuencia de localización mitocondrial de la subnunidad VIII de la citocromo oxidasa mitocondrial (C8), seguido de la secuencia de hemaglutinina (HA) del virus de la gripe humana, que permitirá su detección y localización subcelular (Figura 6) [Vicente-Gutiérrez et al. 2019].

En primer lugar, comprobamos en homogenados celulares la expresión de la catalasa. Para ello, se realizaron cultivos primarios de neuronas corticales de ratón [GómezSánchez et al. 2011] y se realizaron estudios de transferencia tipo western blot, así como ensayos de inmunofluorescencia para la detección de HA (Figura 17). Como se muestra en la Figura 17A, la expresión del tag HA se detecta únicamente en neuronas mCAT y no en neuronas control (wt). Además, observamos que la construcción no afecta negativamente a la cantidad del enzima en neuronas. Del mismo modo, mediante inmunocitoquímica confirmamos la presencia de HA en neuronas mCAT (Figura 17B). 

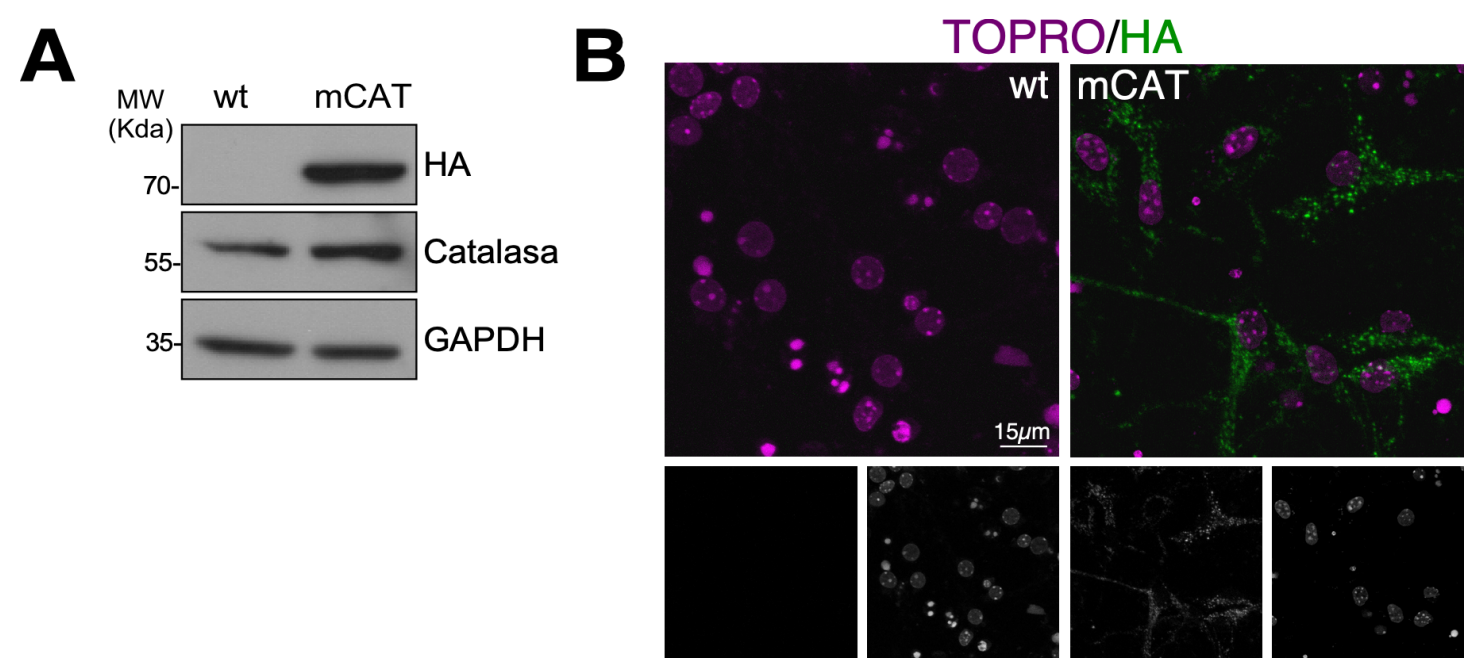

Figura 17. Expresión de la proteína catalasa mitocondrial en homogenados de neuronas corticales mCAT. (A) Inmunodetección de HA y catalasa en homogenados celulares mediante transferencia tipo western blot. Se emplea GAPDH como control de carga. (B) Imágenes representativas de neuronas corticales. Las imágenes muestran el patrón de expresión del tag HA (verde) en neuronas que expresan la catalasa mitocondrial (mCAT). Se utiliza TOPRO-3 (morado) como marcaje nuclear.

Para verificar que nuestra proteína de interés se localiza exclusivamente en las mitocondrias de las neuronas mCAT, realizamos experimentos de fraccionamiento subcelular (Figura 13). De este modo verificamos, por transferencia de tipo western blot, así como mediante técnicas de inmunofluorescencia, que el tag HA y, por tanto, la proteína mCAT, se encuentra únicamente en la fracción mitocondrial (Figura182). Cabe mencionar que la tenue banda observada en citosol podría corresponder a la proteína que está siendo sintetizada y que, posteriormente, migrará hacia su localización mitocondrial (Figura 18A). Como se muestra en la Figura 18B, la detección de marcadores mitocondriales, como son las subunidades enzimáticas MTCO1 (subunidad I de la citocromo c oxidasa, complejo IV) y SDHA (subunidad A de la succinato deshidrogenasa, complejo II) [Vicente-Gutiérrez et al. 2019], nos permitió confirmar la localización mitocondrial de mCAT de una manera más precisa mediante inmunocitoquímica. 
A

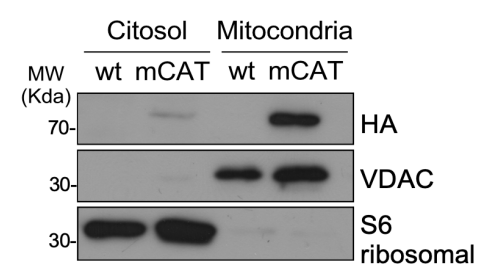

B
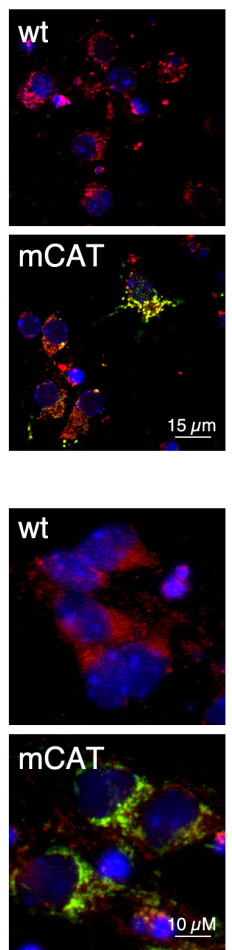

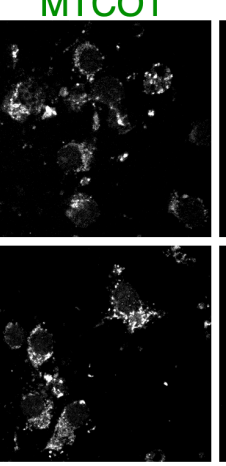

SDHA
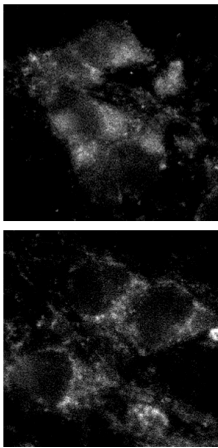

$\mathrm{HA}$

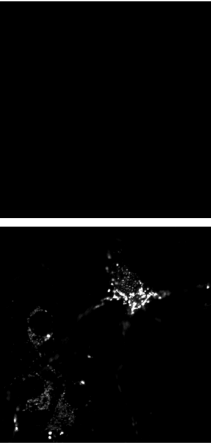

HA

DAPI

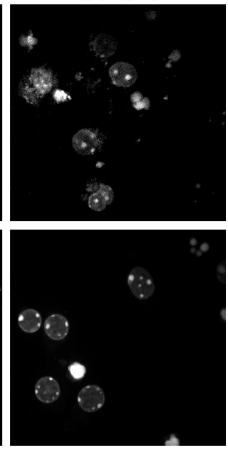

DAPI

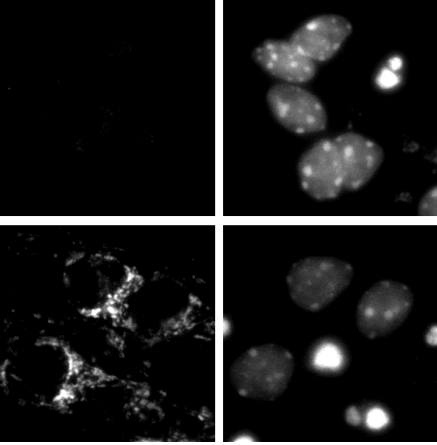

Figura 18. Expresión mitocondrial de la proteína catalasa en fracciones subcelulares de neuronas corticales mCAT. (A) Inmunodetección mediante transferencia tipo western blot. Se emplea VDAC como marcador mitocondrial y S6 como marcador citosólico. (B) Las imágenes representativas muestran el patrón de expresión del tag HA (verde) en neuronas corticales de animales mCAT y su colocalización con los marcadores mitocondriales MTCO1 y SDHA (rojo). Se utiliza DAPI (azul) como marcaje nuclear.

Por tanto, nuestros resultados demuestran que nuestro modelo mCAT expresa correctamente la enzima catalasa y que ésta se acumula en la mitocondria de neuronas corticales de ratón.

\subsection{La presencia de la catalasa en la mitocondria no altera los}

\section{procesos de diferenciación neuronal}

Al tratarse de un modelo constitutivo, quisimos conocer si la expresión ectópica de la enzima catalasa modifica el proceso de diferenciación neuronal in vitro. En primer lugar, realizamos microfotografías de neuronas wt y mCAT a los 3, 6 y 9 días en cultivo (Figura 19). Observamos que no se aprecian diferencias morfológicas aparentes entre ambos genotipos. 

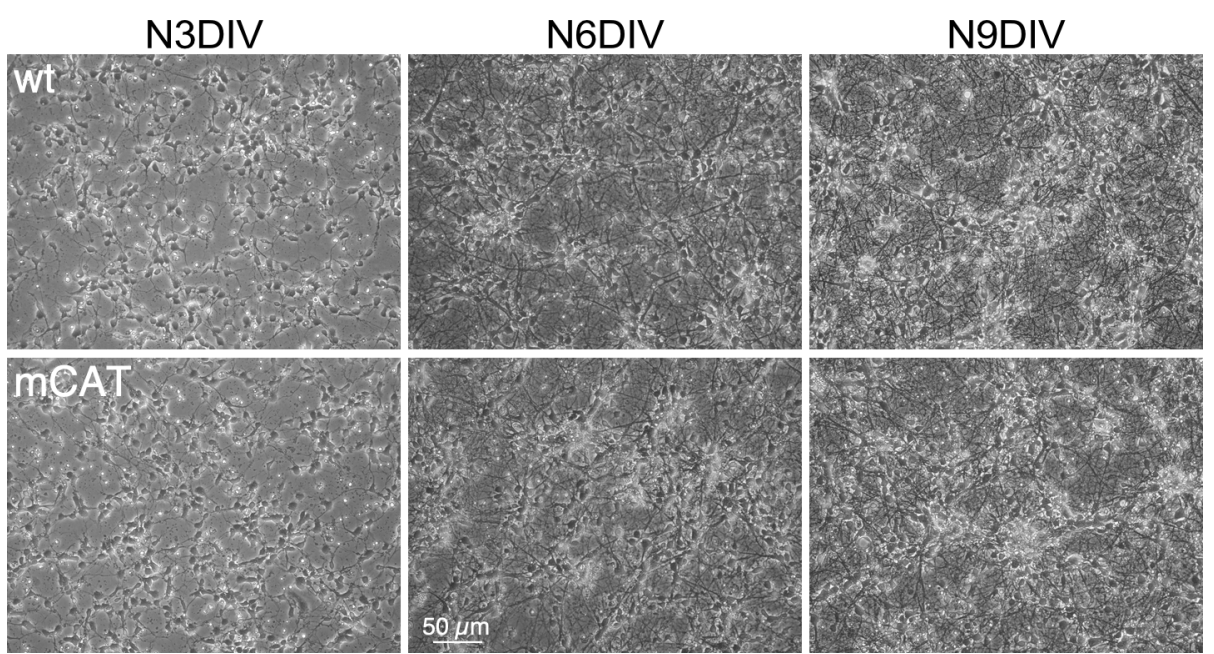

Figura 19. La expresión de catalasa en la mitocondria no afecta a la morfología neuronal. Se realizaron cultivos primarios de neuronas corticales control (wt) y mCAT. Se muestran imágenes representativas de microscopía de contraste de fases de neuronas corticales primarias (N) de ratón wt y mCAT a 3, 6 y 9 días en cultivo in vitro (DIV).

Mediante inmunofluorescencia realizamos el seguimiento del patrón de expresión de la proteína neuronal MAP2 (Microtubule-associated protein 2) durante la diferenciación en cultivo, a los 3, 6 y 9 DIV. Como se muestra en la Figura 4, la expresión mitocondrial de la catalasa no afectó a la expresión de MAP2, lo que parece descartar un efecto de la enzima sobre la diferenciación neuronal (Figura 20).
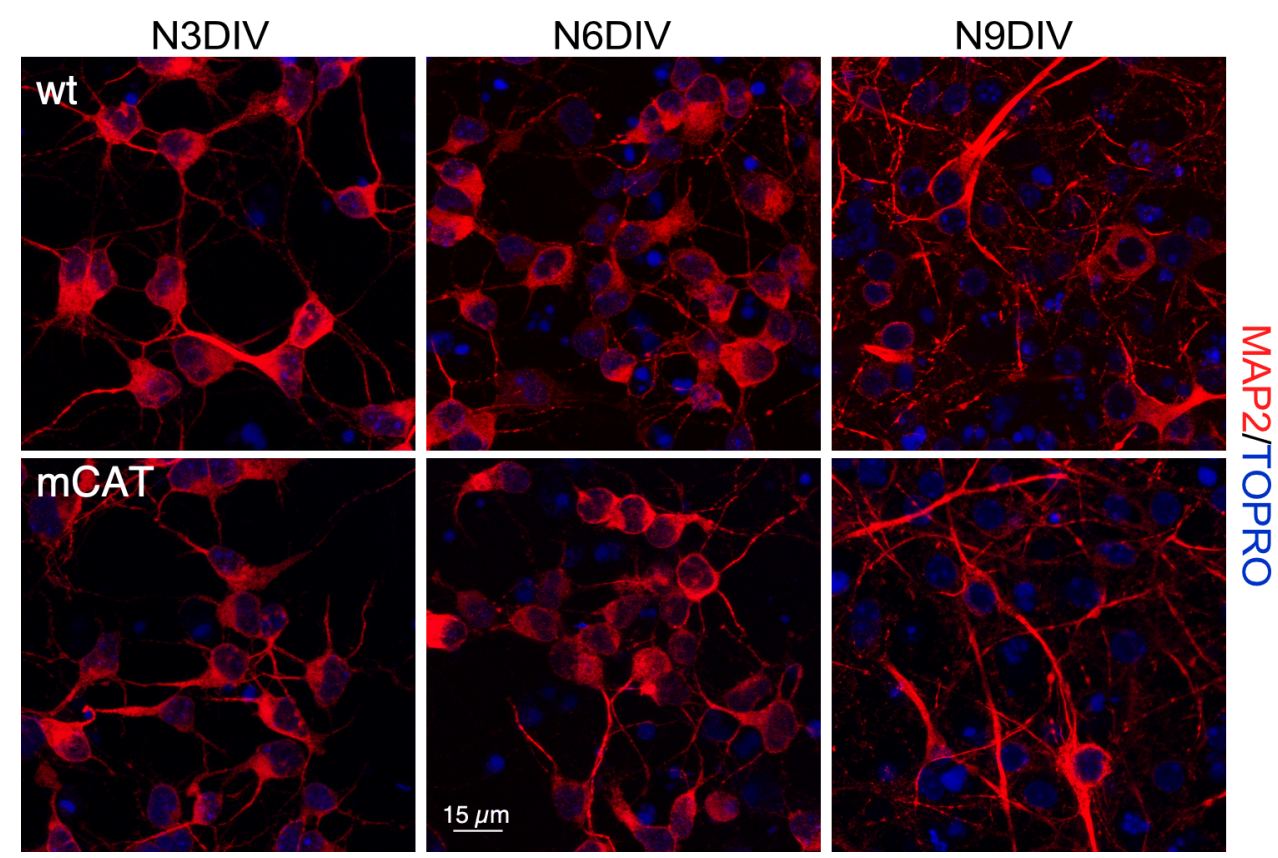

Figura 20. La expresión de catalasa en la mitocondria no afecta a la diferenciación neuronal. Se realizaron cultivos primarios de neuronas corticales control (wt) y mCAT. Se realizó inmunocitoquímica del marcador neuronal MAP2 (rojo) y TOPRO (azul) como marcador nuclear. Se muestran imágenes representativas de microscopía confocal de neuronas corticales primarias (N) de ratón wt y mCAT, a 3, 6 y 9 días en cultivo in vitro (DIV). 
Para estudiar este fenómeno a nivel molecular, realizamos un estudio más exhaustivo incluyendo, además de MAP2, otros indicadores neuronales, como son Tuj-1 (Neuronspecific class III beta-tubulin) y Tau (proteína asociada a microtúbulos) [Dehmelt and Halpain 2005, 204]. Como se muestra en la Figura 21, la expresión de los tres marcadores neuronales es comparable en ambos genotipos. En los dos casos, la expresión de las proteínas MAP2, Tuj1 y Tau incrementó con el tiempo, al menos hasta los 9 DIV. Cabe mencionar que a día 12 de cultivo, se observó un descenso en los niveles de expresión de estas proteínas, que es más pronunciado en las neuronas mCAT. Este hecho podría indicar un envejecimiento prematuro de las neuronas mCAT y, por tanto, un posible papel fisiológico de los ROS mitocondriales en el envejecimiento neuronal, que se abordará en el futuro. En cualquier caso, hay que resaltar que no se observaron diferencias hasta los $9 \mathrm{DIV}$, momento de diferenciación óptimo para la realización de los estudios de excitotoxicidad en neuronas in vitro [Rodríguez et al. 2018, 2437; Lapresa et al. 2019, 19]. Por ello, los experimentos posteriores los realizamos en neuronas de 8-9 DIV.

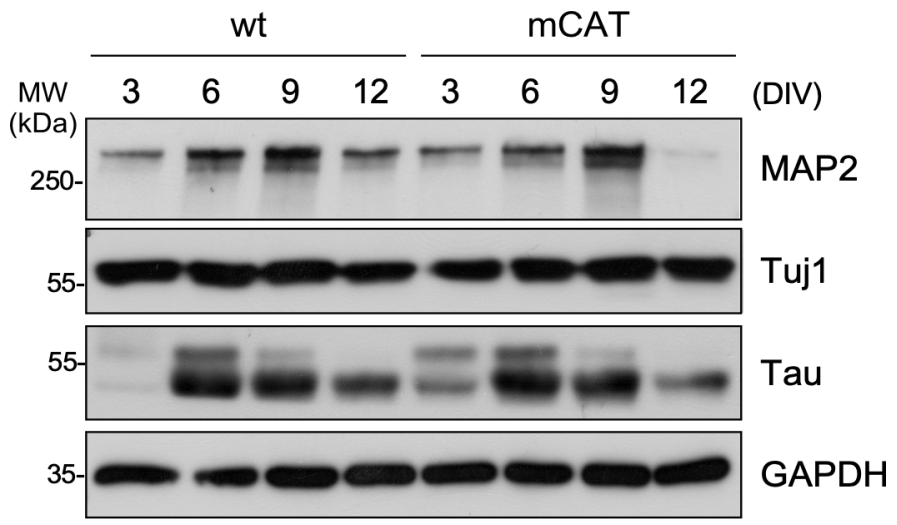

Figura 21. La expresión de catalasa en la mitocondria no afecta a la expresión de marcadores neuronales durante la diferenciación. Imagen representativa de la inmunodetección mediante western blot de los niveles de expresión de MAP2, Tuj1 y Tau en animales control (wt) y mCAT. Se emplea GAPDH como control de carga.

\subsection{La presencia de catalasa en la mitocondria no modifica la}

\section{funcionalidad neuronal}

Una vez demostrado que la localización mitocondrial de la catalasa no afecta a la diferenciación neuronal, quisimos analizar si las características morfológica y funcional de las sinapsis se mantenían inalteradas en el modelo experimental mCAT. 
En una primera aproximación realizamos experimentos de inmunofluorescencia para observar la distribución del marcador presináptico 'Bassoon', una proteína que se localiza en los terminales presinápticos y que participa en la organización estructural del sitio de liberación de neurortansmisores [Richter et al. 1999, 437]. Comprobamos que la expresión de catalasa en la mitocondria (mCAT) no altera el patrón observado en neuronas en cultivo de animales control (wt) (Figura 22).

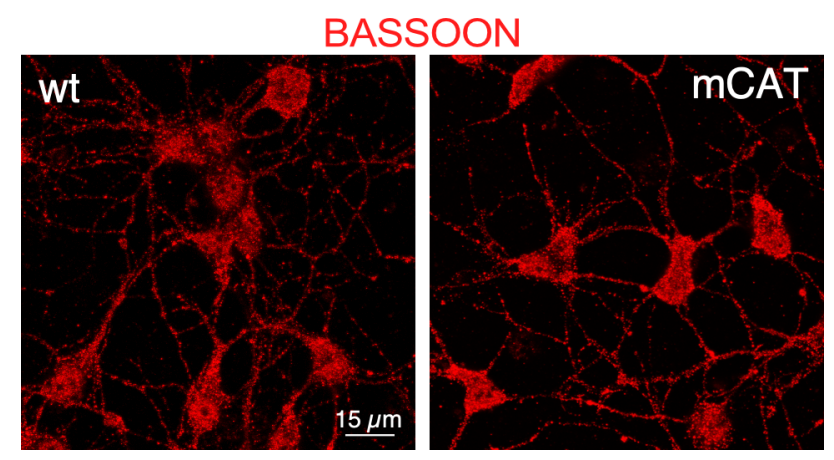

Figura 22. La expresión de catalasa en la mitocondria no afecta a la expresión de marcadores presinápticos Se realizó inmunocitoquímica del marcador Bassoon (rojo). Se muestran imágenes representativas de microscopía confocal de neuronas corticales primarias de ratón wt y mCAT a los 6 días in vitro.

A continuación, estudiamos los niveles de expresión de diferentes marcadores sinápticos: i) Bassoon y sinaptofisina (SYP) como marcadores presinápticos, y ii) PSD95, como marcador postsináptico (Figura 23).

Como ya se ha mencionado, Bassoon es el principal regulador de la composición molecular de los sitios de liberación de neurotransmisores presinápticos [Davydova et al. 2004, 181]. Se trata de una proteína de gran peso molecular localizada en la zona activa de los terminales presinápticos que participa además en la organización estructural de los sitios de liberación de neurotransmisores [Richter et al. 1999, 437]. Adicionalmente, en los terminales presinápticos también se acumula sinaptofisina (SYP), una glicoproteína transmembrara de menor tamaño que se encuentra en pequeñas vesículas presinápticas de las células nerviosas y en las microvesículas de las células neuroendocrinas [Wiedenmann and Franje 1985, 1017]. En ambos casos, demostramos que los niveles de las proteínas presinápticas no se vieron afectados por la presencia de la catalasa en la mitocondria neuronal. Como se muestra en la Figura 23, el patrón observado en neuronas mCAT de 3, 6 y 9 DIV es similar al control (wt). De la misma manera, observamos que la proteína postsináptica PSD-95 (Postsynaptic density protein 95), esencial para la maduración sináptica y la plasticidad neuronal 
[Zheng et al. 2012, 381] se acumuló durante la primera semana de cultivo, de manera que en el día 9 de cultivo, no detectamos diferencias significativas en su patrón de expresión entre ambos genotipos (Figura 23).

Como ya habíamos observado con los marcadores neuronales (Figura 21), los marcadores sinápticos, especialmente Bassoon y PSD-95, disminuyeron a los 12 DIV, siendo la disminución más pronunciada en las neuronas mCAT. Estos resultados confirman un envejecimiento prematuro de las neuronas mCAT. Estos resultados son de gran interés y abre una nueva línea de investigación en nuestro grupo en relación con un posible papel fisiológico de los ROS en el mantenimiento de la homeostasis neuronal y la prevención del envejecimiento prematuro, que se abordará en el futuro.

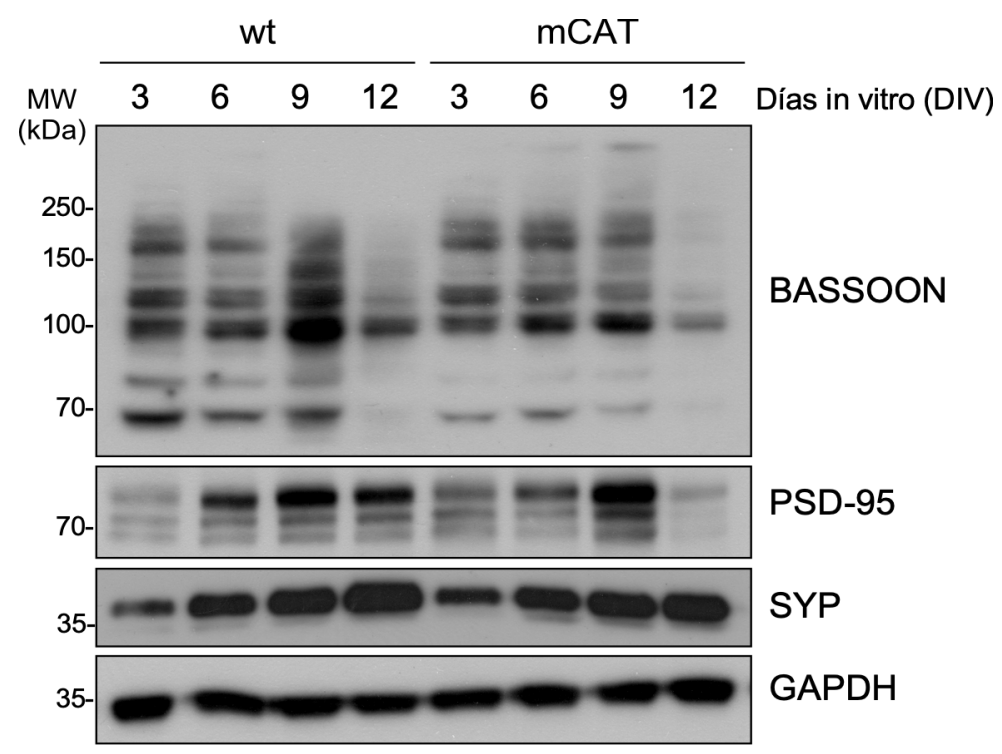

Figura 23. La expresión de catalasa en la mitocondria no afecta a la expresión de marcadores sinápticos. Imagen representativa de la inmunodetección mediante western blot de los niveles de expresión de proteínas pre- (Bassoon, SYP) y post- (PSD-95) sinápticas en animales control (wt) y mCAT. Se emplea GAPDH como control de carga. 


\section{FUNCIÓN NEURPROTECTORA DE LA CATALASA MITOCONDRIAL EN LA EXCITOTOXICIDAD IN VITRO}

\subsection{La presencia de la catalasa en la mitocondria previene el aumento de ROS en neuronas corticales tras la estimulación con glutamato}

Aunque la secuencia de acontecimientos que median la muerte neuronal tras un insulto isquémico no se conoce con exactitud, se sabe que la excitotoxicidad, o muerte neuronal provocada por la estimulación de los receptores de glutamato [Olney et al. 1971, 294; Choi et al. 1988, 623; Bolaños 2009, 1299], desempeña una función esencial en el proceso neurodegenerativo. Por ello, y con objeto de estudiar el efecto de los antioxidantes dirigidos a la mitocondria en fenómenos de neuroprotección recurrimos, como primera aproximación experimental, a un modelo de excitotoxicidad in vitro por estimulación con glutamato, ampliamente utilizado en el grupo [Almeida et al. 1998, 209; Maestre et al. 2008; Gómez-Sánchez et al 2011; Veas Pérez de Tudela et al. 2015]. Lo primero que hicimos fue comprobar si este modelo podría afectar a la expresión de la catalasa mitocondrial en las neuronas de animales mCAT. Para ello, neuronas corticales en cultivo primario de ratones de ambos genotipos (wt y mCAT) se incubaron en presencia de concentraciones excitotóxicas de glutamato (Glu, $100 \mu \mathrm{M})$ o en condiciones control, en presencia de glicina $(10 \mu \mathrm{M})$, durante 10 minutos a $37^{\circ} \mathrm{C}$ [Almeida et al. 1998, 209]. Posteriormente, las neuronas se incubaron en medio de cultivo y se analizaron los niveles de catalasa mediante transferencia tipo western blot, durante 4 ó 24 horas tras la estimulación.

Observamos que los niveles de catalasa, así como del tag HA, no variaron en respuesta al estímulo excitotóxico durante los tiempos de post-estimulación analizados (Figura 24). 


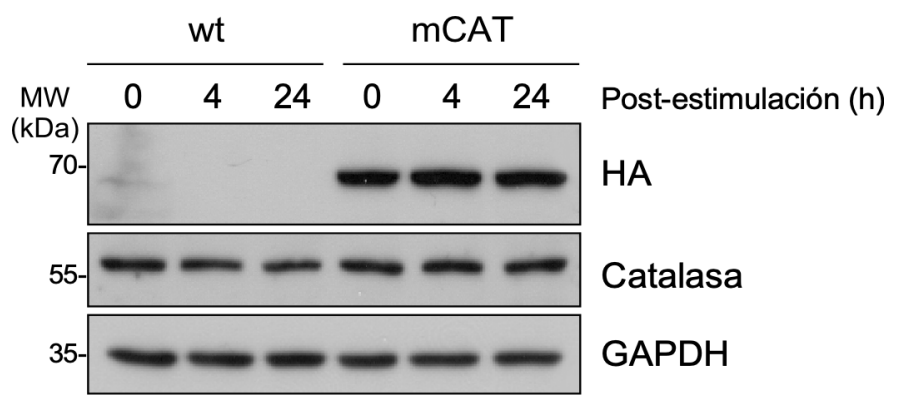

Figura 24. El modelo de excitotoxicidad in vitro no afecta a la expresión de la catalasa en la mitocondria. Neuronas corticales de 9 DIV de ambos genotipos (wt y mCAT) se incubaron en presencia de concentraciones excitotóxicas de glutamato $(100 \mu \mathrm{M})$ y se tomaron muestras a distintos tiempos $(0,4,24 \mathrm{~h})$ post-estimulación. Imagen representativa de la inmunodetección mediante western blot de los niveles de expresión de catalasa y el tag HA. Se utilizó GAPDH como control de carga.

La activación sostenida de los receptores de glutamato, especialmente los receptores NMDA, provoca la apertura de los canales de calcio acoplados a dichos receptores y, en consecuencia, la entrada masiva del ión al interior de la neurona [Bolaños et al 2009]. De hecho, los receptores ionótropicos del glutamato tipo NMDA son los principales responsables del daño neuronal que sigue a la isquemia debido a su mayor permeabilidad al $\mathrm{Ca}^{2+} \mathrm{y}$, por tanto, contribuyen en gran medida al desequilibrio iónico [Gómez-Sánchez et al. 2011; Rodriguez-Rodriguez et al. 2013, 750; Veas Pérez de Tudela et al. 2015], causando la mayoría de los efectos excitotóxicos del glutamato [Yuan et al., 2003, 401; Mehta et al., 2007, 34; Eltzschig et al., 2011, 1391]. En este punto, quisimos investigar si la construcción mCAT podría estar afectando a la funcionalidad de los receptores de glutamato, especialmente a los receptores NMDA. Para ello, se incubaron las neuronas en presencia de concentraciones excitotóxicas de glutamato (100 uM) o NMDA (10 uM), un agonista selectivo del receptor ionotrópico de glutamano, NMDA [Almeida and Bolaños 2001, 676; Jiménez-Blasco et al 2015, 1877]. A continuación, medimos los niveles de $\mathrm{Ca}^{2+}$ citosólico libre utilizando la sonda fluorescente Fura-2 (Figura 9). Como se observa en la Figura 25, la concentración de $\mathrm{Ca}^{2+}$ intracelular aumentó de forma similar en las neuronas de ambos genotipos, después del estímulo excitotóxico, tanto con glutamato como con NMDA. Además, la adición del inhibidor MK801 (10 uM) previno la activación de los receptores NMDA $\mathrm{y}$, en consecuencia, la entrada de $\mathrm{Ca}^{2+}$ en neuronas wt y mCAT. Estos resultados demuestran que la localización mitocondrial de la catalasa no parece interferir en la ruta de activación de los receptores de glutamato y, en consecuencia, en la posterior entrada de $\mathrm{Ca}^{2+}$ en las neuronas. 

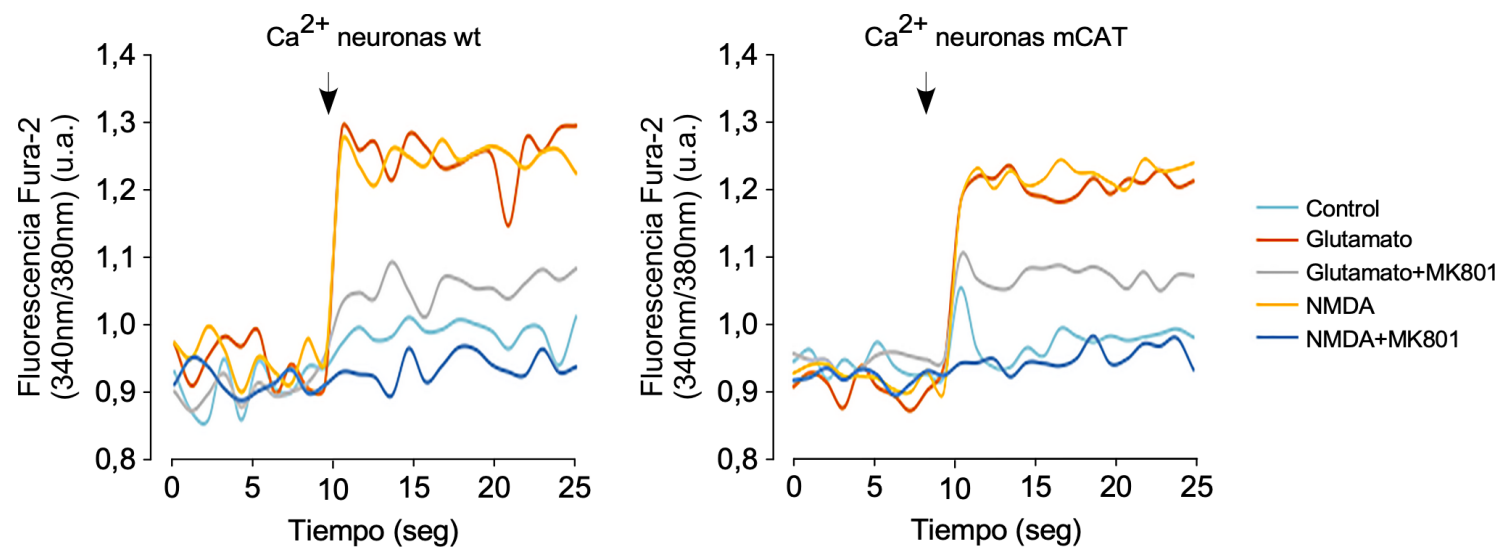

Figura 25. La expresión de catalasa en la mitocondria no afecta a la activación de receptores de glutamato. La estimulación de receptores NMDA con glutamato $(100 \mu \mathrm{M})$ y NMDA $(10 \mu \mathrm{M})$ produjo un incremento en la concentración de $\mathrm{Ca}^{2+}$ citosólico libre en neuronas corticales. Los registros de $\mathrm{Ca}^{2+}$ citosólico libre se realizaron analizando la fluorescencia emitida por la sonda Fura2 después de la excitación a 340/380 nm. El incremento de $\mathrm{Ca}^{2+}$ citosólico como consecuencia de la activación de receptores NMDA se previno con el tratamiento previo con MK801 $(10 \mu \mathrm{M})$. En la condición control se incubaron las neuronas en ausencia de estímulo excitotóxico, únicamente en presencia de glicina (10 mM).

Uno de los principales eventos moleculares que tienen lugar tras un estímulo excitotóxico es la generación de ROS, especialmente ROS mitocondriales [Bolaños and Almeida 1999, 415; Almeida and Bolaños, 2001, 676; Bolaños et al. 2009, 1299]. Por ello, una vez demostrado que las neuronas de ambos genotipos (wt y mCAT) responden de forma similar a un estímulo excitotóxico, quisimos comprobar si las neuronas mCAT, presentaban diferentes niveles de ROS en comparación con las neuronas wt (Figura 26). Con este fin, determinamos la producción de $\mathrm{H}_{2} \mathrm{O}_{2}$ en neuronas wt y mCAT, empleando la sonda fluorescente Amplex ${ }^{\circledR}$ Red. Observamos que la expresión de la catalasa en la mitocondria (mCAT) previno totalmente el aumento en la producción de $\mathrm{H}_{2} \mathrm{O}_{2}$ celular observado en neuronas wt tras la estimulación con glutamato (Figura 26A). Para detectar específicamente la generación de ROS en la mitocondria, utilizamos la sonda fluorescente MitoSox, que se acumula en el orgánulo $\mathrm{y}$, mediante citometría de flujo, nos permite cuantificar la producción de anión superóxido $\left(\mathrm{O}_{2}-{ }^{-}\right)$mitocondrial. Esta sonda fluorescente es permeable a la célula y accede fácilmente a la mitocondria a favor de potencial de membrana mitocondrial $(\Delta \Psi \mathrm{m})$, gracias a un grupo catiónico presente en su molécula. La excitación de la sonda por $\mathrm{O}_{2}-$ produce una modificación con un espectro de emisión de fluorescencia característico que puede ser monitorizado. Así, nuestros resultados mostraron que la estimulación de las neuronas con glutamato indujo un incremento en los niveles de $\mathrm{O}_{2}{ }^{-}$ 
de manera tiempo dependiente. Sin embargo, la presencia de catalasa en la mitocondria previno prevenir dicho incremento de los ROS mitocondriales (Figura 26B).

Estos resultados confirman que la catalasa mitocondrial es funcional, ya que es capaz de prevenir la producción de ROS en neuronas en cultivo tras la estimulación excitotóxica.
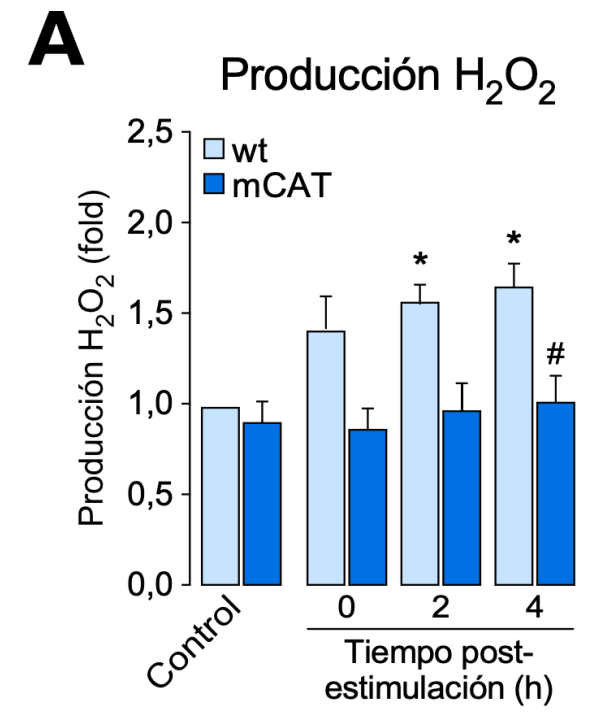

B

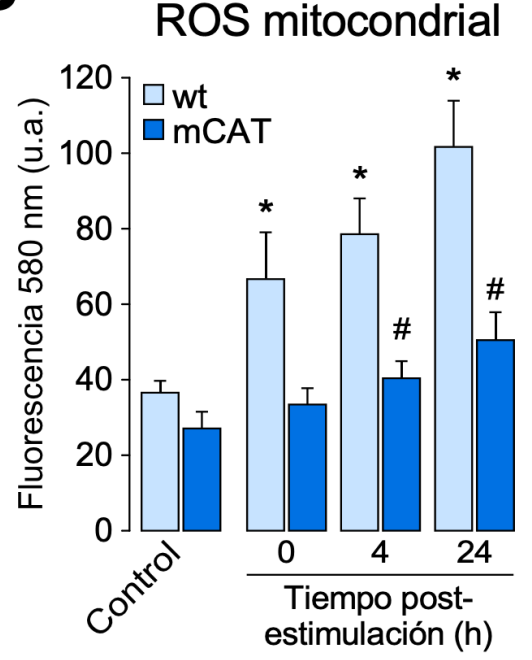

Figura 26. La expresión de catalasa en la mitocondria reduce los niveles de ROS en respuesta a un estímulo excitotóxico. Neuronas corticales de 9 DIV de ambos genotipos (wt y mCAT) se incubaron en presencia de concentraciones excitotóxicas de glutamato $(100 \mu \mathrm{M})$. Se tomaron muestras a distintos tiempos post-estimulación (horas). (A) La determinación de la cinética de liberación de $\mathrm{H}_{2} \mathrm{O}_{2}$ se llevó a cabo mediante la detección fluorimétrica de la sonda Amplex ${ }^{\circledR}$ Red. (B) La sonda MitoSox ${ }^{\circledR}$, sensible a anión superóxido $\left(\mathrm{O}_{2}{ }^{-}\right)$, se empleó para determinar los ROS mitocondriales en ambos genotipos (wt y mCAT) $\left({ }^{*} p<0,05\right.$ vs control; $\# \mathrm{p}<0,05$ vs wt). Los datos son medias \pm S.E.M. de, al menos, 3 cultivos independientes. (ANOVA, post-hoc Bonferroni)

La generación de ROS, fundamentalmente por la mitocondria, es uno de los principales factores responsables de la muerte neuronal causada por la excitotoxicidad [Bolaños and Almeida 1999, 415; Bolaños et al. 2009, 1299]. Por ello, el siguiente paso fue analizar el papel de la terapia antioxidante dirigida a la mitocondria en la supervivencia neuronal en el modelo de excitotoxicidad in vitro. Estudiamos la susceptibilidad de las neuronas al daño excitotóxico con glutamato en ambos genotipos (wt y mCAT), en función del tiempo post-estimulación (Figura 27). En primer lugar, analizamos el porcentaje de neuronas apoptóticas $\left(\mathrm{AnexinaV}^{+} / 7 \mathrm{AAD}^{-}\right)$mediante citometría de flujo (Figura 27A). La estimulación con glutamato produjo un aumento significativo en la muerte neuronal por apoptosis en las neuronas wt. Este incremento fue dependiente del tiempo tras el estímulo excitotóxico. Por el contrario, las neuronas que expresan catalasa en la mitocondra (mCAT) resultaron ser resistentes al daño excitotóxico, tanto 
a las 4 como a las 24 horas post-estimulación. Para confirmar estos resultados, determinamos la actividad de la caspasa-3 mediante fluorimetría, como un segundo marcador de apoptosis neuronal (Figura 27B). Demostramos mediante esta metodología que la presencia de la catalasa en la mitocondria previno el aumento de la actividad de la caspasa-3 tras la estimulación con glutamato, que sí observamos en las neuonas wt.
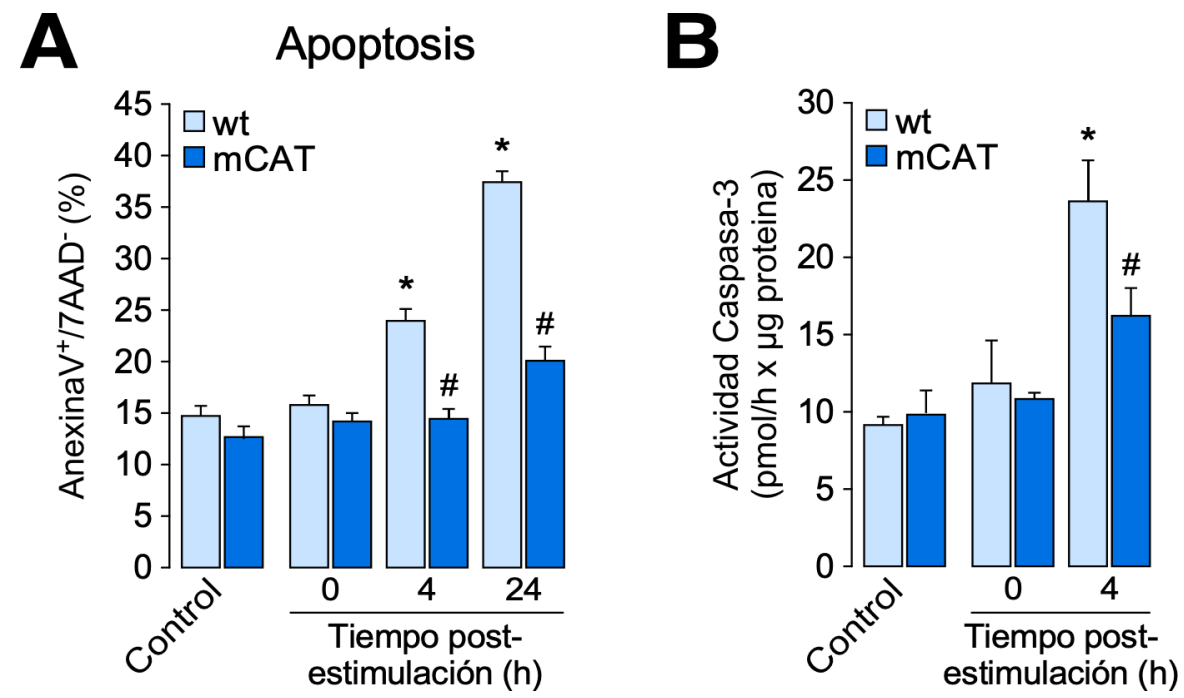

Figura 27. La expresión de catalasa en la mitocondria promueve la supervivencia neuronal después de un estímulo excitotóxico. Neuronas corticales de 9 DIV de ambos genotipos (wt y mCAT) se incubaron en presencia de concentraciones excitotóxicas de glutamato $(100 \mu \mathrm{M})$. Se tomaron muestras a distintos tiempos post-estimulación (horas). (A) Análisis mediante citometría de flujo para determinar el porcentaje de neuronas apoptóticas $\left(\right.$ Anexina $\left.\mathrm{V}^{+} / 7 \mathrm{AAD}^{-}\right)$. (B) Análisis de la actividad de la Caspasa-3 mediante fluorimetría. Los

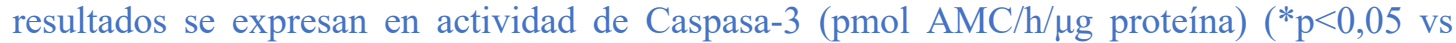
control; $\# \mathrm{p}<0,05 \mathrm{vs} \mathrm{wt})$ Los datos son medias \pm S.E.M. de, al menos, 3 cultivos independientes. (ANOVA, post-hoc Bonferroni)

En conjunto, nuestros resultados demuestran que la expresión de la enzima catalasa en la mitocondria previene la generación de ROS causada por la estimulación de los receptores el glutamato, a pesar de no afectar a la entrada de calcio intracelular. Es más, la mCAT confiere neuroprotección a las neuronas frente a la excitotoxicidad, lo que le convierte en una atractiva herramienta frente al daño isquémico.

\subsection{La presencia de la catalasa en la mitocondria tiene un efecto neuroprotector en la isquemia experimental}

Como hemos comentado, el fenómeno de excitotoxicidad [Olney et al. 1971, 294] tiene lugar después de la isquemia, momento en que se libera gran cantidad de glutamato al 
espacio extracelular. Además, la producción de radicales libres se sabe que contribuye a la neurotoxicidad asociada a la isquemia [Bolaños and Almeida 1999, 415; Bolaños et al. 2009, 1299]. En concreto, se ha visto que durante el periodo de privación de oxígeno y glucosa se produce una acumulación de anión superóxido que inhibe la actividad del complejo I [Bolaños and Almeida 2002, 207]. Estas premisas sugieren que los resultados obtenidos en el modelo con estimulación por glutamato deberían poder extrapolarse a un modelo de isquemia in vitro [Bolaños and Almeida 2002, 207]. Por ello, nuestro siguiente objetivo fue analizar el papel neuroprotector, ejercido por la expresión de catalasa en la mitocondria, en la isquemia experimental. Para ello, realizamos un protocolo de isquemia experimental in vitro, que consiste en incubar a las neuronas en ausencia de glucosa y oxígeno (OGD, Oxygen and Glucose Deprivation), durante 90 minutos. Posteriormente, las neuronas se incubaron el medio de cultivo, en presencia de oxígeno y glucosa, simulando la reoxigenación [Almeida et al. 2002].

En primer lugar, y dado uno de los factores responsables de la muerte neuronal isquémica es la generación de ROS [Bolaños and Almeida 1999, 415; Bolaños et al. $2009,1299]$, quisimos confirmar la producción mitocondrial de anión superóxido $\left(\mathrm{O}_{2}{ }^{-}\right.$ ) en el modelo de OGD. Como se muestra en la Figura 28, la presencia de la catalasa en la mitocondria (mCAT) previno el aumento de ROS causado por la OGD y posterior reoxigenación, observado en animales control (wt). Por tanto, la expresión de mCAT podría tener un efecto neuroprotector frente a la isquemia, como hemos observado en condiciones excitotóxicas.

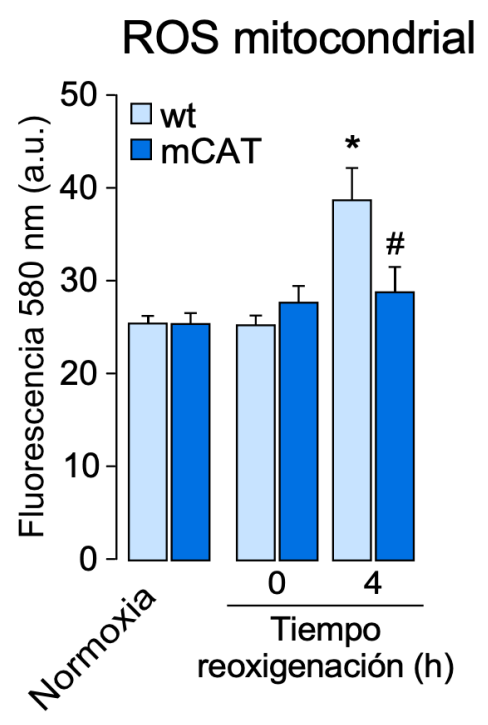


Figura 28. La expresión de catalasa en la mitocondria reduce los niveles de ROS en respuesta a la isquemia experimental in vitro. Neuronas corticales de 9 DIV de ambos genotipos (wt y mCAT) se incubaron en ausencia de glucosa y $\mathrm{O}_{2}<1 \%$ durante 90 minutos. Se tomaron muestras a distintos tiempos de reoxigenación (horas). Como control se llevó la condición de Normoxia, incubando las células en presencia de glucosa y $\mathrm{O}_{2} 21 \%$. Se empleó la sonda MitoSox ${ }^{\circledR}$, sensible a anión superóxido $\left(\mathrm{O}_{2}{ }^{-}\right)$, para determinar los ROS mitocondriales en ambos genotipos (wt y mCAT) $(* p<0,05$ vs control; $\# p<0,05$ vs wt). Los datos son medias \pm S.E.M. de, al menos, 3 cultivos independientes. (ANOVA, post-hoc Bonferroni)

Para evaluar la posible actividad neuroprotectora de la expresión de catalasa en la mitocondria tras la OGD, analizamos la apoptosis neuronal mediante la detección de neuronas Anexina $\mathrm{V}^{+} / 7 \mathrm{AAD}^{-}$por citometría de flujo (Figura 29). Mientras que el modelo de isquemia experimental incrementó la apoptosis en las neuronas wt, las neuronas mCAT resultaron ser resistentes al insulto isquémico. Por tanto, la expresión de catalasa en la mitocondria tiene un efecto neuroprotector frente a la isquemia in vitro.

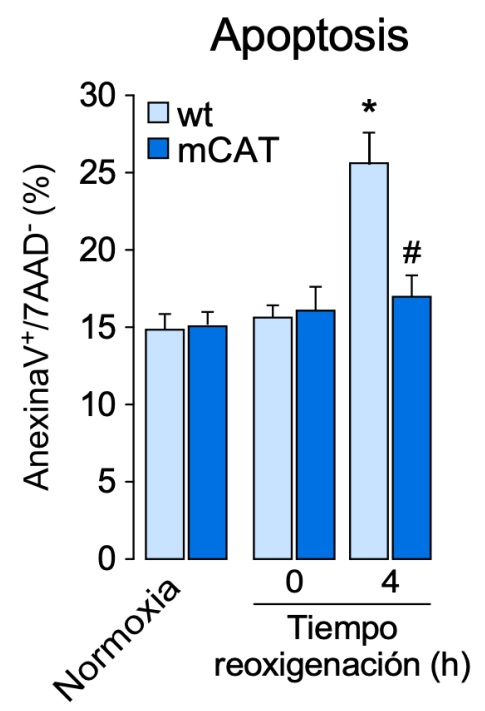

Figura 29. La expresión de catalasa en la mitocondria previene la muerte neuronal después de la isquemia experimental. Neuronas corticales de 9 DIV de ambos genotipos (wt y mCAT) se incubaron en ausencia de glucosa y $\mathrm{O}_{2}<1 \%$ durante 90 minutos. Se tomaron muestras a distintos tiempos de reoxigenación (horas). Como control se llevó la condición de Normoxia, incubando las células en presencia de glucosa y $\mathrm{O}_{2} 21 \%$. Análisis mediante citometría de flujo para determinar el porcentaje de neuronas apoptóticas (AnexinaV $\left.\mathrm{V}^{+} / 7 \mathrm{AAD}^{-}\right)$ $\left({ }^{*} \mathrm{p}<0,05\right.$ vs control; $\# \mathrm{p}<0,05$ vs wt) Los datos son medias \pm S.E.M. de, al menos, 3 cultivos independientes. (ANOVA, post-hoc Bonferroni)

Adicionalmente, realizamos ensayos de inmunofluorescencia empleando anticuerpos específicos contra la Caspasa-3 activa, en cultivos de neuronas de ambos genotipos tras del protocolo de OGD (Figura 30). 


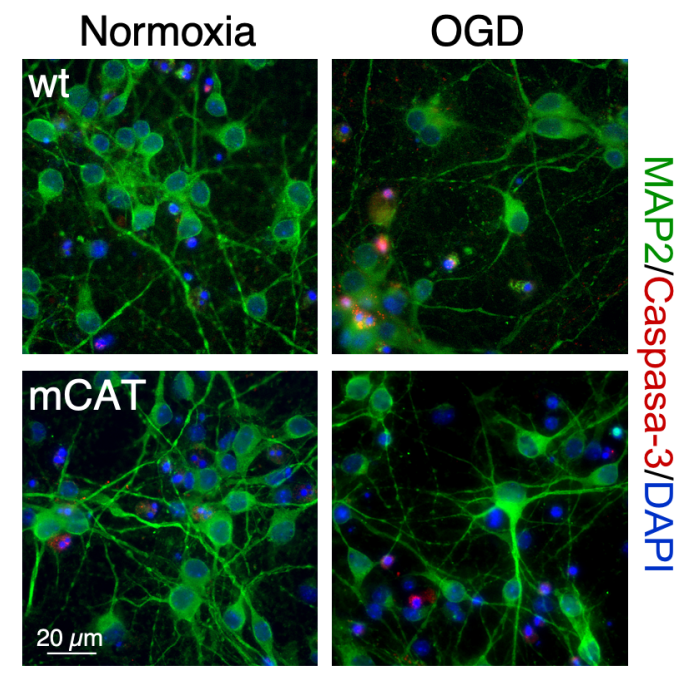

Figura 30. La expresión de catalasa en la mitocondria promueve la supervivencia neuronal tras la isquemia in vitro. Neuronas corticales de 9 DIV de ambos genotipos (wt y mCAT) se incubaron en ausencia de glucosa y $\mathrm{O}_{2}<1 \%$ durante 90 minutos. Como control se llevó la condición de Normoxia, incubando las células en presencia de glucosa y $\mathrm{O}_{2} 21 \%$. A las 4 horas de reoxigenación se realizó inmunocitoquímica del marcador neuronal MAP2 (verde), Capasa-3 activa (rojo) y DAPI (azul) como marcador nuclear. Se tomaron imágenes de epifluorescencia de neuronas corticales primarias de ratón wt y mCAT.

Los resultados en neuronas corticales en cultivo primario nos permiten concluir que la expresión de la catalasa en la mitocondria es neuroprotectora. Así, la enzima previene la generación de ROS y, con ello, la muerte neuronal en condiciones excitotóxicas, como es la isquemia. Por tanto, la terapia antioxidante dirigida a la mitocondria podría representar una nueva herramienta en el desarrollo de nuevas terapias en los procesos isquémicos, como en el ictus.

\section{EFECTO NEUROPROTECTOR DE LA CATALASA}

\section{MITOCONDRIAL EN LA ISQUEMIA CEREBRAL IN VIVO}

Los modelos animales representan una mejor aproximación traslacional de los resultados experimentales que los cultivos celulares. De hecho, los modelos in vivo de isquemia cerebral han sido y son esenciales para estudiar los procesos fisiopatológicos implicados en la isquemia y establecer nuevas vías de actuación terapéutica frente al daño isquémico. Por ello, nuestro siguiente objetivo fue confirmar la función neuroprotectora de la terapia antioxidante dirigida a la mitocondria en un modelo de isquemia cerebral in vivo. Ratones wt $(+/+)$ y ratones mCAT $(+/ m C A T)$ se sometieron a un modelo de oclusión transitoria de la arteria cerebral media (tMCAO) (Figura 15) [Rodríguez et al. 2018, 2437]. Como se muestra en la Figura 31, el volumen de lesión a 
las 24 horas de la isquemia experimental resultó ser significativamente menor en los animales mCAT $\left(25,5 \pm 2,6 \mathrm{~mm}^{3}\right)$ respecto a los animales control $\left(53,5 \pm 7,4 \mathrm{~mm}^{3}\right)$. Esta reducción de aproximadamente un 50\%, demuestra que la presencia de catalasa en la mitocondria tiene un importante efecto neuroprotector frente al daño isquémico in vivo, lo que concuerda con los resultados observados in vitro.

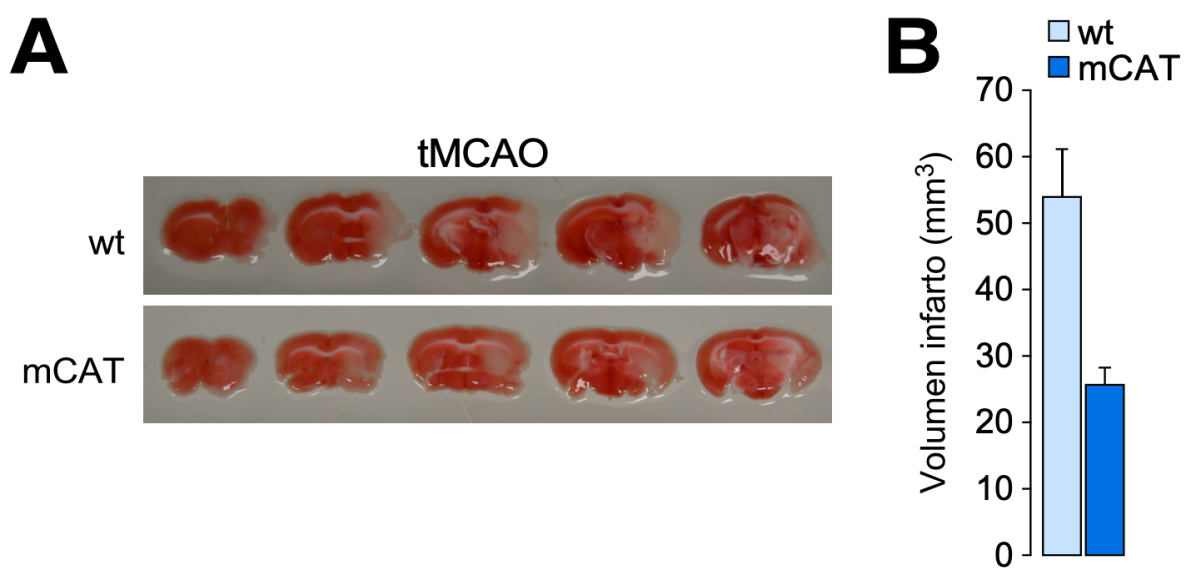

Figura 31. La expresión de catalasa en la mitocondria reduce el volumen de lesión en ratones mCAT después de la isquemia in vivo. Ratones de ambos genotipos, wt $(+/+)$ y mCAT $(+/ \mathrm{mCAT})$, se sometieron a isquemia experimental in vivo (oclusión transitoria de la arteria cerebral media, tMCAO, 30 minutos). (A) Imágenes representativas de secciones de cerebros de ratones wt y mCAT a las 24 horas después de la oclusión. (B) El volumen de lesión $\left(\mathrm{mm}^{3}\right)$ se determinó en secciones histológicas mediante tinción con cloruro de tetrazolio (TTC). Los valores se expresan como medias \pm S.E.M. ( $\mathrm{n}=3$ ratones por grupo). $(\# \mathrm{p}<0,05 \mathrm{vs} \mathrm{wt})(t d e$ Student)

Ante situaciones de estrés celular, se produce la estabilización de la proteína supresora de tumores p53 y, como consecuencia, la parada de ciclo celular, senescencia y/o apoptosis, dependiendo del contexto celular [Jin and Levine 2001, 4139; Culmsee and Mattson 2005, 716]. Tras la isquemia cerebral, p53 se acumula y activa rápidamente en el tejido dañado, provocando la apoptosis celular, especialmente en neuronas, lo que finalmente condiciona el daño cerebral y, con ello, el pronóstico funcional de los pacientes de ictus [Gómez-Sánchez et al. 2011, 429; Rodríguez et al. 2017, 144; Rodríguez et al. 2018, 2437]. Es más, la prevención o disminución de la apoptosis neuronal tras la isquemia se plantea como una posible vía de actuación para mitigar el daño cerebral y, con ello, la recuperación funcional de los pacientes de ictus [Almeida 2013, 71]. Por ello, nuestro siguiente objetivo fue estudiar el posible impacto de la terapia antioxidante dirigida a la mitocondria en la apoptosis celular causada por la isquemia/reperfusión in vivo. Así, ratones de ambos genotipos, wt (+/+) y mCAT $(+/$ mCAT), se sometieron al modelo de tMCAO durante 30 minutos y se determinó la apoptosis en secciones cerebrales mediante la técnica de TUNEL. Como se muestra en 
la Figura 32, el número de células apoptóticas $\left(\mathrm{TUNEL}^{+}\right)$fue menor en los cerebros de animales mCAT que en los wt, a las 24 horas del daño isquémico. Es más, mediante la doble tinción con el marcador neuronal NeuN y TUNEL $\left(\mathrm{NeuN}^{+}, \mathrm{TUNEL}^{+}\right)$, demostramos que la apoptosis neuronal en el hemisferio infartado fue significativamente menor en los ratones que expresan mCAT, que en los ratones control (wt) (Figura 32). Estos resultados aportan solidez a los obtenidos en cultivos de neuronas in vitro y demuestran que la expresión de la catalasa en la mitocondria protege a las neuronas del daño isquémico, lo que probablemente condicione una mejor recuperación funcional tras la isquemia.
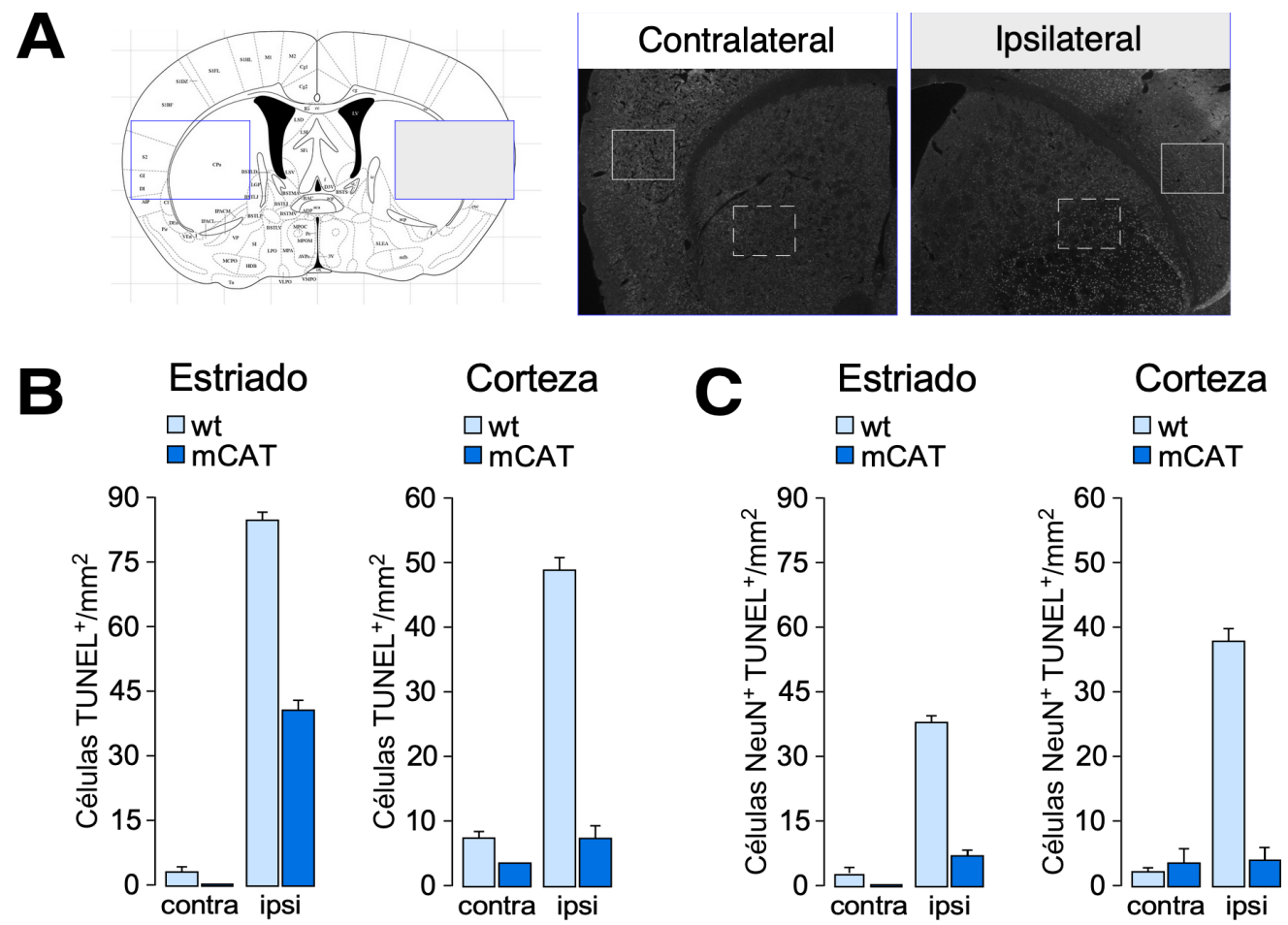

Figura 32. La expresión de catalasa en la mitocondria protege a las neuronas mCAT de la muerte por apoptosis después de la isquemia in vivo. Ratones de ambos genotipos, wt $(+/+)$ y mCAT $(+/$ mCAT), se sometieron a isquemia experimental in vivo (oclusión transitoria de la arteria cerebral media, tMCAO, 30 minutos). (A) Imágenes representativas de la zona seleccionada para cuantificar la apoptosis celular en secciones de cerebros de ratones wt y mCAT, a las 24 horas después de la oclusión. (B) Cuantificación de la apoptosis celular (células $\mathrm{TUNEL}^{+}$) en dos regiones del cerebro (estriado y corteza) de hemisferio contralateral (contral: sano) e ipsilateral (ipsi: dañado). (C) Cuantificación de la apoptosis neuronal (células $\mathrm{NeuN}^{+}$ TUNEL $^{+}$) Los valores se expresan como medias \pm S.E.M. ( $n=3$ ratones por grupo; al menos 3 medidas en cada región/animal). ( ${ }^{*} \mathrm{p}<0,05$ vs control; $\# \mathrm{p}<0,05$ vs wt) (ANOVA, post-hoc Bonferroni)

Está bien documentado que el estrés oxidativo que sufren las células tras la isquemia produce lesiones en el DNA. Es más, las neuronas son especialmente susceptibles al 
daño neuronal inducido por la isquemia [Huttner et al. 2014, 801]. Principalmente se producen modificaciones puntuales, oxidación o pérdida de bases nitrogenadas, que dan lugar a roturas de cadena sencilla del DNA [Li et al. 2018, 208]. Este tipo de daño oxidativo en el DNA ha sido ampliamente estudiado en las últimas décadas y se sabe está asociado a fenómenos de neurodegeneración [Canugovi et al. 2013, 578]. Recientemente, se ha demostrado que las neuronas también tienen la capacidad de reparar roturas de doble hebra en el DNA, un daño más severo que se produce tanto en condiciones fisiológicas como patológicas [Suberbielle et al. 2013, 613; Madabhushi et al. 2014,266]. En nuestro laboratorio hemos demostrado que el daño en el DNA está estrechamente ligado a la supervivencia neuronal después de la isquemia [SánchezMorán, Tesis Doctoral, 2018]. Dado que mCAT previene el estrés oxidativo y, en consecuencia, incrementa la supervivencia neuronal tras la isquemia, decidimos analizar la posible protección de la enzima sobre la integridad del DNA. Para ello, ratones wt y mCAT se sometieron al modelo de isquemia cerebral in vivo y se analizó la acumulación de histona $\mathrm{H} 2 \mathrm{AX}$ fosforilada $(\gamma \mathrm{H} 2 \mathrm{AX})$, conocido marcador de daño genómico [Rogakou et al. 1998, 5858; Delgado-Esteban et al. 2013, 2879], mediante transferencia tipo western blot (Figura 33) e inmunofluorescencia (Figura 34). Nuestros resultados mostraron que la expresión de mCAT previno el daño oxidativo en el DNA, como revela la disminución en los niveles de la acumulación de $\gamma \mathrm{H} 2 \mathrm{AX}$ en neuronas a las 24 horas tras de la isquemia (Figura 33). Es más, mediante inmunofluorescencia confirmamos dicha disminución en distintas regiones (estriado y corteza), tanto del hemisferio sano (contralateral) como del hemisferio dañado (ipsilateral), en animales de ambos genotipos wt y mCAT (Figura 34).

El daño en el DNA provoca la estabilización de p53, lo que parece ser responsable de la muerte celular asociada a la inestabilidad genómica [Hafner et al. 2019, 199]. Dado que p53 está implicada en el daño isquémico [Almeida, 2013, 71], nuestro siguiente paso fue detectar los niveles de p53 tras la isquemia experimental en los ratones wt y mCAT. Como se muestra en la Figura 33, la expresión de catalasa en la mitocondria previno la estabilización de p53, de manera similar al efecto observado sobre la acumulación de daño en el DNA $(\gamma \mathrm{H} 2 \mathrm{AX})$.

Por tanto, en condiciones isquémicas, la generación de ROS en la mitocondria provoca daño oxidativo en el DNA y la consecuente la estabilización de p53, lo que culmina en la apoptosis neuronal. La activación de un sistema antioxidante en la mitocondria, como 
es la catalasa, previene dicha cascada neurotóxica, lo que le convierte en una buena diana a tener en cuenta para el desarrollo de terapias neuroprotectoras en el ictus isquémico.

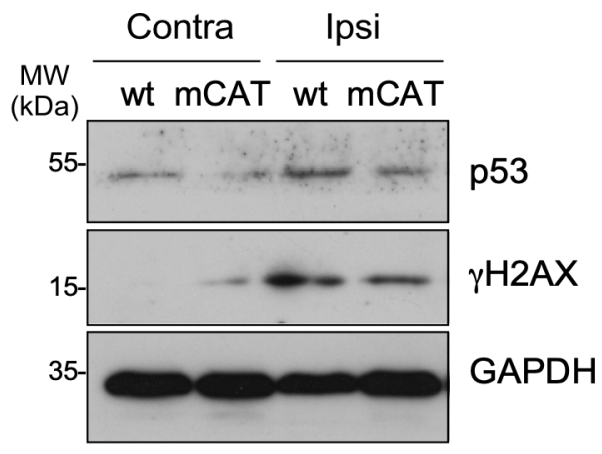

Figura 33. La expresión de catalasa en la mitocondria previene la estabilización de p53 y el daño en el DNA después de la isquemia in vivo. Imagen representativa de la inmunodetección mediante western blot de los niveles de expresión de p53 y $\gamma \mathrm{H} 2 \mathrm{AX}$ (marcador de daño en el DNA) en hemisferio contralateral (contra: sano) e ipsilateral (ipsi: dañado) de animales wt (+/+) y mCAT (+/mCAT), después de la isquemia experimental in vivo (oclusión transitoria de la arteria cerebral media, tMCAO, 30 minutos). Se empleó GAPDH como control de carga.
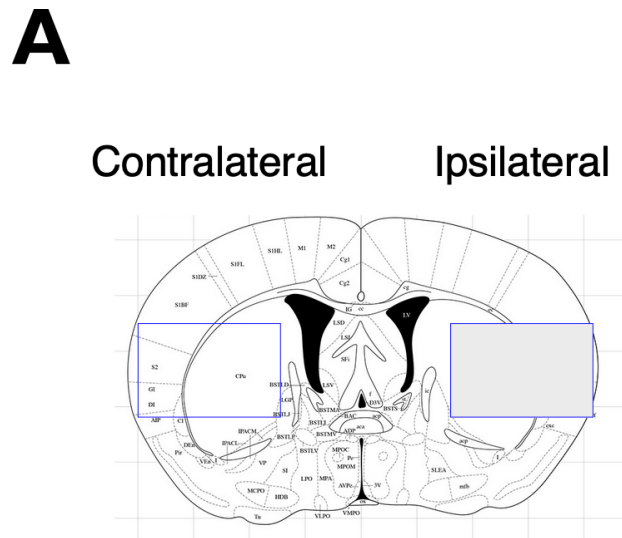

B

Estriado $\square$ wt

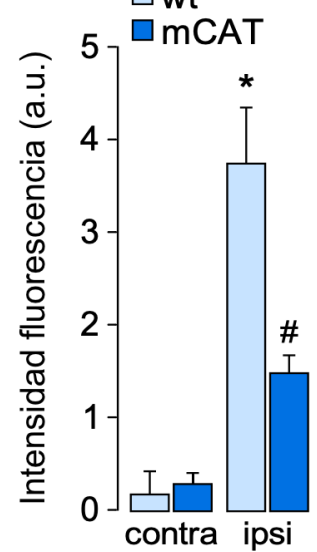

Corteza

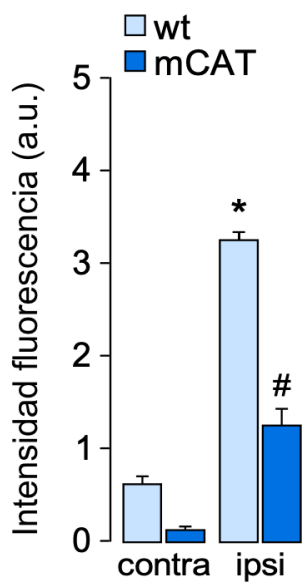

Figura 34. La expresión de catalasa en la mitocondria protege a las neuronas mCAT del daño oxidativo en el DNA después de la isquemia in vivo. Ratones de ambos genotipos, wt $(+/+)$ y mCAT $(+/$ mCAT), se sometieron a isquemia experimental in vivo (oclusión transitoria de la arteria cerebral media, tMCAO, 30 minutos). (A) Imágenes representativas de la zona seleccionada para cuantificar la señal de $\gamma \mathrm{H} 2 \mathrm{AX}$ en secciones de cerebros de ratones wt y mCAT a las 24 horas después de la oclusión. (B) Cuantificación de la intensidad de fluorescencia en dos regiones del cerebro (estriado y corteza) de hemisferio contralateral (contra: control) e ipsilateral (ipsi: dañado). Los valores se expresan como medias \pm S.E.M. $\left(\mathrm{n}=3\right.$ ratones por grupo; al menos 3 medidas en cada región/animal). ( ${ }^{*} \mathrm{p}<0,05$ vs control; $\# \mathrm{p}<0,05$ vs wt) (ANOVA, post-hoc Bonferroni) 


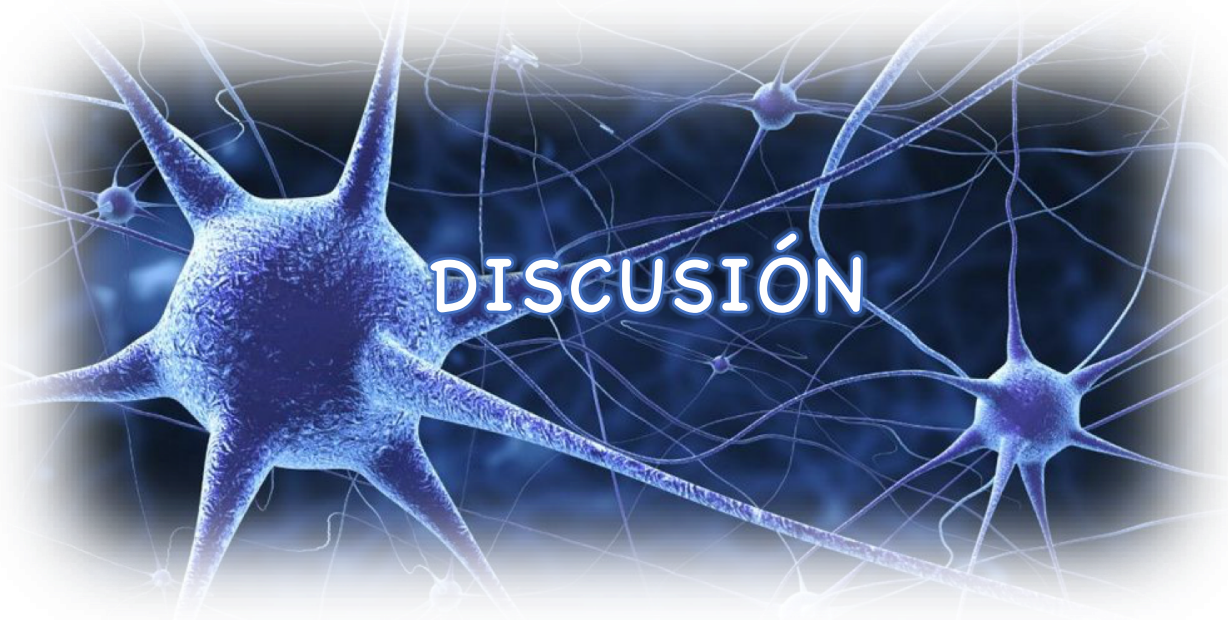


El ictus es una enfermedad cerebrovascular muy prevalente en países desarrollados, es la causa principal de discapacidad en el adulto y una importante causa también de mortalidad [Boehme et al. 2017, 472]. Por tanto, el ictus es considerado un grave problema asistencial y social, en continuo crecimiento, que requiere estrategias específicas para la detección, el manejo y el tratamiento [Feigin et al. 2015, 161]. El tratamiento del ictus en su fase aguda tiene como objetivo fundamental la restauración rápida del flujo sanguíneo cerebral y la limitación y reparación de los tejidos afectados [Rengel et al., 2018, 90]. En la actualidad, en algunos casos, esos objetivos se pueden lograr mediante terapia farmacológica con el uso de trombolíticos, como el t-PA, o técnicas intervencionistas como la trombectomía mecánica, o la combinación de ambas. En ambas situaciones, el objetivo es recanalizar la arteria ocluida para restablecer el flujo sanguíneo (reperfusión) rápidamente en el área del infarto. Esta recanalización, a pesar de resultar fundamental para recuperar la función cerebral, provoca la oxigenación del tejido dañado y, en consecuencia, la generación de especies reactivas de oxígeno y nitrógeno, que son responsables del daño celular durante la reperfusión [Bolaños et al, 2009; Eltzschig and Eckle 2011, 1391; Granger and Kvietys, 2015, 255]. En este punto, cobra especial importancia la terapia antioxidante, ya que podría disminuir o incluso evitar el daño tisular producido por los radicales libres [Rachel et al. 2014, 472]. Así, el interés por la neuroprotección se justificaría como un intento de mejora sustancial en el pronóstico de los pacientes de ictus [Chamorro et al. 2016, 869]. Con esta premisa, en los últimos años se han llevado a cabo multitud de estudios preclínicos con sustancias neuroprotectoras. Muchos de ellos se han completado con éxito, si bien la mayoría han fracasado en su traslación a la clínica [Lo et al. 2003, 399; Sutherland et al. 2012, 407]. Es posible que la mayoría de los compuestos ensayados presenten dificultades para alcanzar una concentración adecuada en la zona dañada y, más específicamente, en la localización subcelular oportuna [Murphy 2014, 20]. Es decir, el fracaso podría deberse a que los antioxidantes utilizados no consigan llegar a la fuente intracelular generadora de los ROS. Puesto que la mitocondria es el principal productor de ROS en la célula [Bolaños et al 2009], consideramos que el diseño de una estrategia antioxidante dirigida específicamente a este orgánulo podría ser de gran relevancia para el desarrollo de nuevos tratamientos neuroprotectores en ictus. En el presente trabajo, hemos utilizado un modelo murino que expresa de forma constitutiva la enzima catalasa en la mitocondria (modelo mitocatalasa o mCAT) [VicenteGutiérrez et al. 2019, 201]. Con este modelo, podemos analizar de una manera precisa 
el impacto de una terapia antioxidante dirigida específicamente a la mitocondria en la muerte neuronal causada por la isquemia. Adicionalmente, nuestro modelo permite estudiar el posible efecto de la ausencia de ROS mitocondriales endógenos sobre el proceso de la diferenciación neuronal.

La localización mitocondrial es otro punto importante de nuestro modelo mCAT, ya que la catalasa que expresan en la mitocondria detoxifica el $\mathrm{H}_{2} \mathrm{O}_{2}$, modificando mínimamente el metabolismo [Vicente-Gutiérrez et al. 2019, 201]. De hecho, hasta el momento, se han descrito diferentes modelos animales para modular la cantidad de ROS mitocondriales endógenos que no contemplan este punto y sí tienen repercusiones metabólicas. Puede ser bien porque sobreexpresan enzimas, como superóxido dismutasa mitocondrial (MnSOD), que detoxifican anión superóxido generando otras especies reactivas como $\mathrm{H}_{2} \mathrm{O}_{2}$ [Chen et al. 1998, 2281], o bien porque reducen los niveles de $\mathrm{H}_{2} \mathrm{O}_{2}$ como nuestro modelo, pero lo hacen sobreexpresando enzimas dependientes de nicotinamida como la peroxiredoxina [Matsushima et al. 2006, 1179]. Puesto que necesitan NADPH para su regeneración, estarían alterando el ratio $\mathrm{NADPH} / \mathrm{NADP}^{+}$y el estado redox y, en consecuencia, el metabolismo celular. Otro modelo muy interesante para reducir los ROS mitocondriales consiste en la expresión de glutamato-cisteina ligasa en la mitocondria (mGCL) [Quintana-Cabrera et al. 2012]. Sin embargo, este sistema consume ATP, cisteína y glutamato por lo que puede modificar también el metabolismo de las células. En la literatura existe un precedente que emplea una forma de catalasa dirigida a la mitocondria [Schiner et al. 2005, 1909]. A diferencia de nuestro modelo, los autores no consiguen la inserción dirigida del gen ni tampoco el control del número de copias insertadas. Por tanto, es posible que los efectos que observan puedan ser resultado de cambios en la expresión de otros genes. Todo ello hace que nuestro modelo sea idóneo para estudiar el efecto de la generación de radicales libres mitocondriales sobre diferentes procesos celulares, tanto en condiciones fisiológicas, como puede ser la diferenciación neuronal, como patológicas, como la isquemia cerebral.

En condiciones fisiológicas, los ROS pueden tener un papel importante en la diferenciación neuronal y el mantenimiento de las sinapsis [Oswald, 2018, 679]. Los resultados descritos en la presente memoria demuestran que la expresión de catalasa en la mitocondria de neuronas no interfiere en la diferenciación neuronal ni formación de sinápsis, al menos hasta los 9 días de cultivo. Así, la expresión de marcadores 
estructurales del estado de diferenciación neuronal, como MAP2, Tuj1 y Tau, así como de proteínas sinápticas, como Bassoon, sinaptofisina y PSD-95, esenciales para el establecimiento de sinapsis funcionales [Zheng et al. 2012, 381], en las neuronas mCAT presentan un patrón de expresión similar al observado en animales control. Ciertamente a día 12 de cultivo, observamos un descenso significativo, principalmente en MAP2 y proteínas sinápticas Bassoon y PSD-95, en ambos genotipos, si bien el descenso es más evidente en las neuronas mCAT. No podemos descartar que se trate de un fenotipo de envejecimiento como consecuencia de la pérdida de ROS señalizadores. Esto, sin duda, resulta de gran interés y abre una nueva línea de investigación en nuestro grupo en relación con un posible papel fisiológico de los ROS en el mantenimiento de la homeostasis neuronal y la prevención del envejecimiento prematuro, que se abordará en el futuro.

El cerebro es un tejido muy vulnerable al estrés oxidativo [Bolaños, 2016, 115; Cobley et al. 2018, 490], situación que, como hemos comentado, se produce de manera brusca tras un ictus. En realidad, durante la isquemia cerebral tiene lugar una cascada de señalización compleja de eventos fisiopatológicos que incluyen excitotoxicidad, estrés oxidativo, inflamación y apoptosis, entre otros [Lo et al. 2003, 399; Chamorro et al 2016]. El conocimiento de los mecanismos moleculares implicados en la lesión isquémica es necesario para el desarrollo de nuevas estrategias terapeúticas en ictus [Patel and McMullen 2017, 542]. En concreto, entender cómo funcionan los mecanismos antioxidantes y encontrar una aproximación eficaz para reducir el estrés oxidativo y trasladar a la clínica -algo hasta el momento inexistente- es una de las premisas de la neuroprotección para paliar el daño asociado a la reperfusión de tejidos [Lo et al. 2003, 399; Sutherland et al. 2012, 407; Chamorro et al. 2016, 869]. Ello es especialmente importante en la actualidad, con el uso de la trobectomía y/o trombólisis, como terapia de elección en ictus isquémico. En este contexto, el modelo mCAT resulta ideal, ya que modula directamente los efectos del estrés oxidativo en su origen, la mitocondria. Además, nos permite utilizar diversos modelos experimentales bien caracterizados en nuestro grupo que mimetizan el daño por isquemia/reperfusión, tanto in vitro, excitotoxicidad con glutamato [Almeida et al. 1998, 209; Veas Pérez de Tudela et al. 2015] y OGD en cultivo primario de neuronas [Almeida 2002, 207; GómezSánchez et al. 2011, 429], como in vivo, mediante la oclusión transitoria de la arteria cerebral media (tMCAO) [Fluri et al. 2005, 3445; Rodríguez et al. 2018, 2437]. 
Mediante el empleo de estos modelos, hemos demostrado que la expresión de la catalasa en la mitocondria reduce significativamente los niveles de $\mathrm{H}_{2} \mathrm{O}_{2}$ y ROS tras la isquemia/reperfusión. Está descrito que el desequilibrio oxidativo ligado al daño por isquemia/reperfusión es uno de los principales desencadenantes de la muerte neuronal, ya que activa cascadas de señalización implicadas en procesos de apoptosis y necrosis [Almeida et al. 2001, 676; Almeida et al. 2002, 207; Bolaños et al. 2002, 2227; Bolaños et al. 2009, 1299]. Nuestros resultados indican que la menor producción de ROS en la mitocondria de animales mCAT después de la isquemia previene la apoptosis neuronal. Este hecho es algo que hemos comprobado por distintas técnicas in vitro (citometría de flujo, estudios de fluorimetría e inmunofluorescencia en cultivos de neuronas corticales después de OGD) e in vivo (técnica de TUNEL en animales después de tMCAO). Por tanto, la terapia antioxidante dirigida a la mitocondria tiene una importante función neuroprotectora contra el daño oxidativo tras la isquemia. Esta terapia podría utilizarse como coadyuvante a la trombectomía, ya que aportaría protección frente al daño oxidativo asociado a la recanalización, mejorando la recuperación funcional de los pacientes de ictus.

El mantenimiento de la integridad del DNA es esencial para la supervivencia neuronal [Huttner 2014, 801]. Así, el estrés oxidativo que se genera tras un proceso isquémico es nocivo, especialmente para las neuronas [Crow et al. 2006, 2351; Li et al. 2011, 1905]. En contra de lo que se pensaba, se ha descrito que las neuronas tienen la capacidad de reparar roturas de doble hebra en el DNA, un daño más severo que se produce en condiciones fisiológicas, durante la neurotransmisión, y patológicas, como la enfermedad de Alzheimer [Suberbielle et al. 2013, 613; Madabhushi et al. 2014, 266; Suberbielle et al. 2015, 8897]. En nuestro laboratorio hemos descrito recientemente que este tipo de daño en el DNA está estrechamente ligado a la apoptosis neuronal después de la isquemia [Sánchez-Morán, Tesis Doctoral, 2018]. En el presente trabajo confirmamos que la isquemia in vivo provoca roturas de doble cadena en el DNA, como revela la expresión de $\gamma \mathrm{H} 2 \mathrm{AX}$, y, en consecuencia, la estabilización de la proteína proapoptótica p53. Sin embargo, la expresión de la catalasa en la mitocondria previene tanto el daño oxidativo en el DNA, como muestra la menor acumulación de $\gamma \mathrm{H} 2 \mathrm{AX}$ en neuronas de cerebros infartados, como la estabilización de p53. Teniendo en cuenta que, por un lado, p53 se estabiliza mediante fosforilación por la quinasa ATM en repuesta a un daño en el DNA [Hafner et al. 2019, 199] y, por otro, promueve la muerte 
celular por apoptosis en isquemia cerebral [Gómez-Sánchez et al. 2011; Almeida, 2013, 71], la ausencia de p53 en los animales mCAT podría ser responsable de la mayor supervivencia neuronal observada en los animales mCAT. Es más, resultados previos del grupo resaltan la importancia de los niveles de p53 en el daño cerebral y pronóstico funcional de los pacientes de ictus [Gómez-Sánchez et al. 2011; Rodriguez et al. 2018]. Todo ello sugiere que la expresión de catalasa en la mitocondria es un buen modelo de partida para el diseño de nuevas herramientas terapéuticas dirigidas a la neuroprotección y mejora del pronóstico de los pacientes de ictus. Además, este modelo podría resultar interesante en el estudio y tratamiento de otras enfermedades neurodegenerativas en las que la disfunción mitocondrial y el estrés oxidativo son factores determinantes, como es la enfermedad de Alzheimer o de Parkinson [Mattson and Arumugam 2018]. 


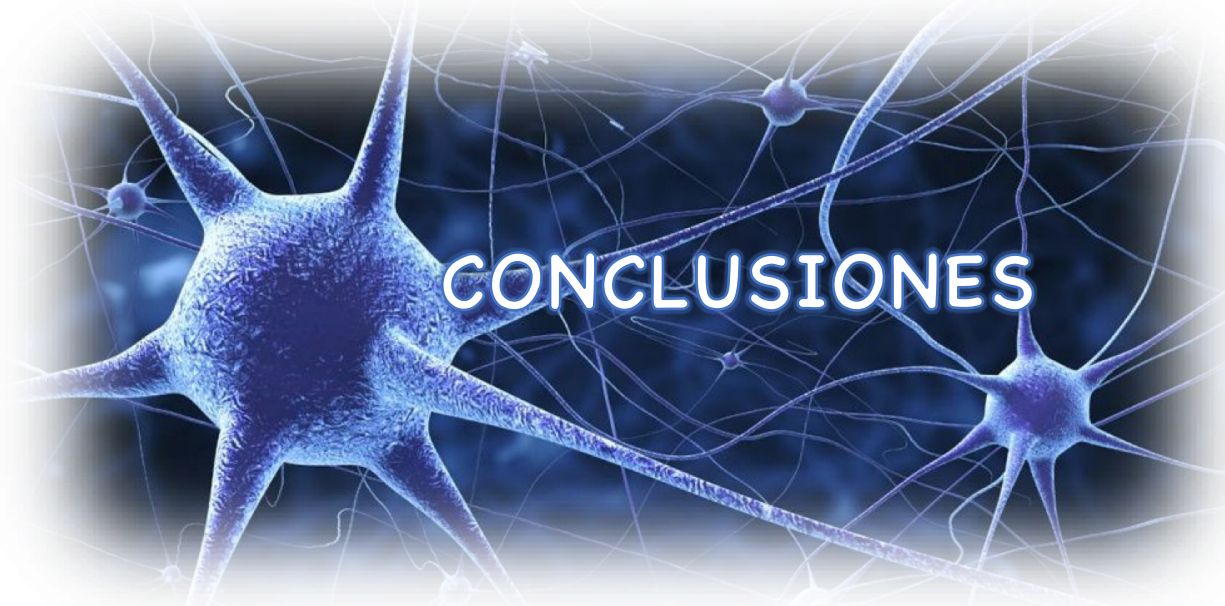




\section{CONCLUSIONES}

De acuerdo con los resultados obtenidos en el presente trabajo de Tesis Doctoral, podemos concluir:

1. Mediante el uso de un modelo murino transgénico que expresa constitutivamente la enzima antioxidante catalasa en la mitocondria, hemos demostrado que la ausencia de radicales libres endógenos no afecta a la diferenciación neuronal, al menos hasta los 9 días de cultivo, momento en que las neuronas son plenamente maduras y funcionales.

2. La expresión de la catalasa en la mitocondria es neuroprotectora, ya que previene el estrés oxidativo y la subsecuente apoptosis neuronal tras un proceso isquémico, tanto in vitro como in vivo. Por tanto, la terapia antioxidante dirigida a la mitocondria podría ser una buena herramienta para el desarrollo de nuevas terapias neuroprotectoras en ictus.

3. El daño en el DNA y la subsecuente estabilización de p53 que se producen en el cerebro dañado en respuesta a la isquemia, se previene en el modelo murino de expresión de catalasa en la mitocondria. Por tanto, la terapia antioxidante dirigida a la mitocondria protege al DNA frente al daño oxidativo causado por la isquemia, lo que impide la estabilización de p53 y, con ello, la progresión del daño cerebral isquémico. Todo ello, es esencial para promover la recuperación funcional tras un ictus.

\section{Conclusión final}

Los resultados recogidos en el presente trabajo demuestran que la terapia antioxidante dirigida a la mitocondria representa una nueva y eficaz herramienta neuroprotectora frente al daño isquémico. Así, la expresión de la catalasa en la mitocondria previene el daño oxidativo en el DNA y la consecuente estabilización de p53, promoviendo la supervivencia neuronal tras la isquemia, lo que podría estar vinculado con una mejor recuperación funcional de pacientes que sufren ictus isquémico. Por ello, la terapia antioxidante dirigida a la mitocondria aquí identificada podría utilizarse como coadyuvante a las terapias actualmente utilizadas, como la trombectomía y/o trombólisis, ya que aportaría protección frente al daño oxidativo durante la recanalización, mejorando así la recuperación funcional de los pacientes de ictus isquémico. 


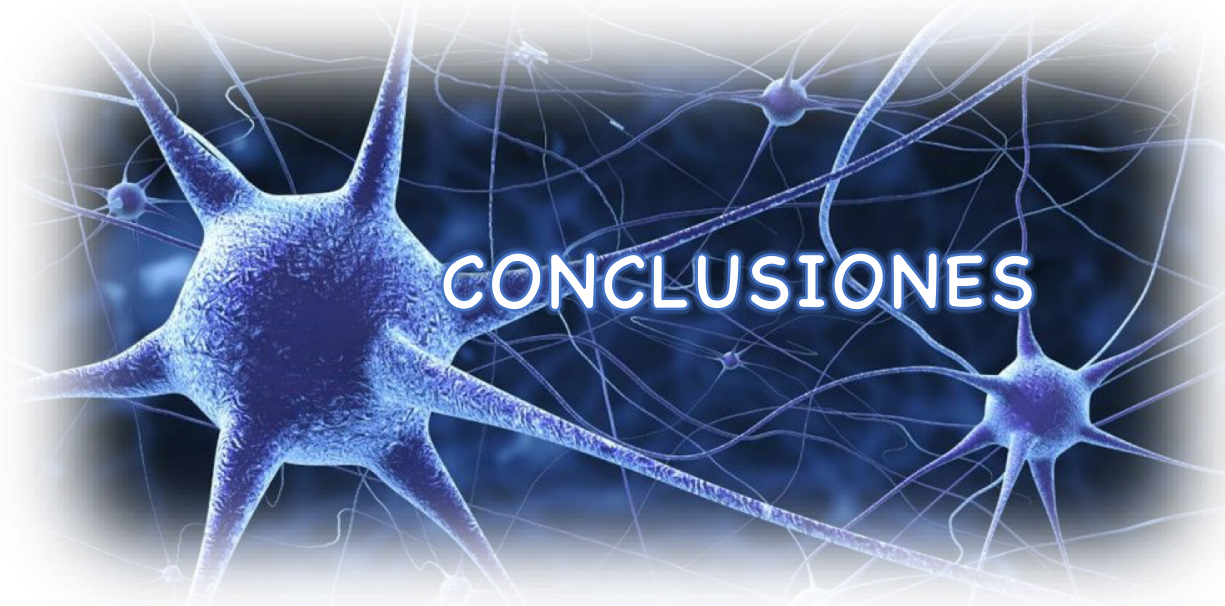




\section{BIBLIOGRAFÍA}

Acín-Pérez, R., Fernández-Silva, P., Peleato, M., Pérez-Martos, A. and Enriquez, J. (2008). Respiratory Active Mitochondrial Supercomplexes. Molecular Cell, 32(4), pp.529-539.

Almeida, A. (2012). Genetic determinants of neuronal vulnerability to apoptosis. Cellular and Molecular Life Sciences, 70(1), pp.71-88.

Almeida, A. and Medina, J. (1998). A rapid method for the isolation of metabolically active mitochondria from rat neurons and astrocytes in primary culture. Brain Research Protocols, 2(3), pp.209-214.

Almeida, A., Almeida, J., Bolanos, J. and Moncada, S. (2001). Different responses of astrocytes and neurons to nitric oxide: The role of glycolytically generated ATP in astrocyte protection. Proceedings of the National Academy of Sciences, 98(26), pp.15294-15299.

Almeida, A., Delgado-Esteban, M., Bolaños, J. and Medina, J. (2002). Oxygen and glucose deprivation induces mitochondrial dysfunction and oxidative stress in neurones but not in astrocytes in primary culture. Journal of Neurochemistry, 81(2), pp.207-217.

Almeida, A., Moncada, S. and Bolaños, J. (2003). Nitric oxide switches on glycolysis through the AMP protein kinase and 6-phosphofructo-2-kinase pathway. Nature Cell Biology, 6(1), pp.45-51.

Angelova, P. and Abramov, A. (2016). Functional role of mitochondrial reactive oxygen species in physiology. Free Radical Biology and Medicine, 100, pp.81-85.

Anrather, J. and Iadecola, C. (2016). Inflammation and Stroke: An Overview. Neurotherapeutics, 13(4), pp.661-670. 
Araújo, I., Carreira, B., Carvalho, C. and Carvalho, A. (2010). Calpains and Delayed Calcium Deregulation in Excitotoxicity. Neurochemical Research, 35(12), pp.19661969.

Attwell, D. and Laughlin, S. (2001). An Energy Budget for Signaling in the Grey Matter of the Brain. Journal of Cerebral Blood Flow \& Metabolism, 21(10), pp.1133-1145.

Bakkenist, C. and Kastan, M. (2004). Initiating Cellular Stress Responses. Cell, 118(1), pp.9-17.

Bandera, E., Botteri, M., Minelli, C., Sutton, A., Abrams, K. and Latronico, N. (2006). Cerebral Blood Flow Threshold of Ischemic Penumbra and Infarct Core in Acute Ischemic Stroke. Stroke, 37(5), pp.1334-1339.

Barzilai, A. and Yamamoto, K. (2004). DNA damage responses to oxidative stress. DNA Repair, 3(8-9), pp.1109-1115.

Basuroy, S., Bhattacharya, S., Leffler, C. and Parfenova, H. (2009). Nox4 NADPH oxidase mediates oxidative stress and apoptosis caused by TNF- $\alpha$ in cerebral vascular endothelial cells. American Journal of Physiology-Cell Physiology, 296(3), pp.C422C432.

Beal, M., Oakes, D., Shoulson, I., Henchcliffe, C., Galpern, W., Haas, R., Juncos, J., Nutt, J., Voss, T., Ravina, B., Shults, C., Helles, K., Snively, V., Lew, M., Griebner, B., Watts, A., Gao, S., Pourcher, E., Bond, L., Kompoliti, K., Agarwal, P., Sia, C., Jog, M., Cole, L., Sultana, M., Kurlan, R., Richard, I., Deeley, C., Waters, C., Figueroa, A., Arkun, A., Brodsky, M., Ondo, W., Hunter, C., Jimenez-Shahed, J., Palao, A., Miyasaki, J., So, J., Tetrud, J., Reys, L., Smith, K., Singer, C., Blenke, A., Russell, D., Cotto, C., Friedman, J., Lannon, M., Zhang, L., Drasby, E., Kumar, R., Subramanian, T., Ford, D., Grimes, D., Cote, D., Conway, J., Siderowf, A., Evatt, M., Sommerfeld, B., Lieberman, A., Okun, M., Rodriguez, R., Merritt, S., Swartz, C., Martin, W., King, P., Stover, N., Guthrie, S., Watts, R., Ahmed, A., Fernandez, H., Winters, A., Mari, Z., Dawson, T., Dunlop, B., Feigin, A., Shannon, B., Nirenberg, M., Ogg, M., Ellias, S., Thomas, C., Frei, K., Bodis-Wollner, I., Glazman, S., Mayer, T., Hauser, R., Pahwa, R., Langhammer, A., Ranawaya, R., Derwent, L., Sethi, K., Farrow, B., Prakash, R., 
Litvan, I., Robinson, A., Sahay, A., Gartner, M., Hinson, V., Markind, S., Pelikan, M., Perlmutter, J., Hartlein, J., Molho, E., Evans, S., Adler, C., Duffy, A., Lind, M., Elmer, L., Davis, K., Spears, J., Wilson, S., Leehey, M., Hermanowicz, N., Niswonger, S., Shill, H., Obradov, S., Rajput, A., Cowper, M., Lessig, S., Song, D., Fontaine, D., Zadikoff, C., Williams, K., Blindauer, K., Bergholte, J., Propsom, C., Stacy, M., Field, J., Mihaila, D., Chilton, M., Uc, E., Sieren, J., Simon, D., Kraics, L., Silver, A., Boyd, J., Hamill, R., Ingvoldstad, C., Young, J., Thomas, K., Kostyk, S., Wojcieszek, J., Pfeiffer, R., Panisset, M., Beland, M., Reich, S., Cines, M., Zappala, N., Rivest, J., Zweig, R., Lumina, L., Hilliard, C., Grill, S., Kellermann, M., Tuite, P., Rolandelli, S., Kang, U., Young, J., Rao, J., Cook, M., Severt, L. and Boyar, K. (2014). A Randomized Clinical Trial of High-Dosage Coenzyme Q10 in Early Parkinson Disease. JAMA Neurology, 71(5), p.543.

Bedard, K. and Krause, K. (2007). The NOX Family of ROS-Generating NADPH Oxidases: Physiology and Pathophysiology. Physiological Reviews, 87(1), pp.245-313.

Bergui, M., Stura, G., Daniele, D., Cerrato, P., Berardino, M. and Bradac, G. (2006). Mechanical Thrombolysis in Ischemic Stroke Attributable to Basilar Artery Occlusion as First-Line Treatment. Stroke, 37(1), pp.145-150.

Boehme, A., Esenwa, C. and Elkind, M. (2017). Stroke Risk Factors, Genetics, and Prevention. Circulation Research, 120(3), pp.472-495.

Bolaños, J. (2016). Bioenergetics and redox adaptations of astrocytes to neuronal activity. Journal of Neurochemistry, 139, pp.115-125.

Bolaños, J. and Almeida, A. (1999). Roles of nitric oxide in brain hypoxia-ischemia. Biochimica et Biophysica Acta (BBA) - Bioenergetics, 1411(2-3), pp.415-436.

Bolaños, J., Almeida, A., Stewart, V., Peuchen, S., Land, J., Clark, J. and Heales, S. (2002). Nitric Oxide-Mediated Mitochondrial Damage in the Brain: Mechanisms and Implications for Neurodegenerative Diseases. Journal of Neurochemistry, 68(6), pp.2227-2240. 
Bolaños, J., Moro, M., Lizasoain, I. and Almeida, A. (2009). Mitochondria and reactive oxygen and nitrogen species in neurological disorders and stroke: Therapeutic implications 2 . Advanced Drug Delivery Reviews, 61(14), pp.1299-1315.

Bouzier-Sore, A. and Bola $\tilde{A} \pm$ os, J. (2015). Uncertainties in pentose-phosphate pathway flux assessment underestimate its contribution to neuronal glucose consumption: relevance for neurodegeneration and aging. Frontiers in Aging Neuroscience, 7.

Brand, M. (2010). The sites and topology of mitochondrial superoxide production. Experimental Gerontology, 45(7-8), pp.466-472.

Broughton, B., Reutens, D. and Sobey, C. (2009). Apoptotic Mechanisms After Cerebral Ischemia. Stroke, 40(5).

Brouns, R. and De Deyn, P. (2009). The complexity of neurobiological processes in acute ischemic stroke. Clinical Neurology and Neurosurgery, 111(6), pp.483-495.

Bustin, S., Benes, V., Garson, J., Hellemans, J., Huggett, J., Kubista, M., Mueller, R., Nolan, T., Pfaffl, M., Shipley, G., Vandesompele, J. and Wittwer, C. (2009). The MIQE Guidelines: Minimum Information for Publication of Quantitative Real-Time PCR Experiments. Clinical Chemistry, 55(4), pp.611-622.

Caldeira, M., Salazar, I., Curcio, M., Canzoniero, L. and Duarte, C. (2014). Role of the ubiquitin-proteasome system in brain ischemia: Friend or foe? Progress in Neurobiology, 112, pp.50-69.

Caso, J., Pradillo, J., Hurtado, O., Leza, J., Moro, M. and Lizasoain, I. (2008). TollLike Receptor 4 Is Involved in Subacute Stress-Induced Neuroinflammation and in the Worsening of Experimental Stroke. Stroke, 39(4), pp.1314-1320.

Caso, J., Pradillo, J., Hurtado, O., Lorenzo, P., Moro, M. and Lizasoain, I. (2007). TollLike Receptor 4 Is Involved in Brain Damage and Inflammation After Experimental Stroke. Circulation, 115(12), pp.1599-1608. 
Chance, B., Sies, H. and Boveris, A. (1979). Hydroperoxide metabolism in mammalian organs. Physiological Reviews, 59(3), pp.527-605.

Charriaut-Marlangue, C., Margaill, I., Represa, A., Popovici, T., Plotkine, M. and BenAri, Y. (1996). Apoptosis and Necrosis after Reversible Focal Ischemia: An in Situ DNA Fragmentation Analysis. Journal of Cerebral Blood Flow \& Metabolism, 16(2), pp.186-194.

Chelikani, P., Fita, I. and Loewen, P. (2004). Diversity of structures and properties among catalases. Cellular and Molecular Life Sciences (CMLS), 61(2), pp.192-208.

Chipuk, J., Moldoveanu, T., Llambi, F., Parsons, M. and Green, D. (2010). The BCL2 Family Reunion. Molecular Cell, 37(3), pp.299-310.

Choi, I., Lee, C., Kim, H., Choi, D. and Lee, J. (2018). Effect of Inhibition of DNA Methylation Combined with Task-Specific Training on Chronic Stroke Recovery. International Journal of Molecular Sciences, 19(7), p.2019.

Chouchani, E., Pell, V., Gaude, E., Aksentijević, D., Sundier, S., Robb, E., Logan, A., Nadtochiy, S., Ord, E., Smith, A., Eyassu, F., Shirley, R., Hu, C., Dare, A., James, A., Rogatti, S., Hartley, R., Eaton, S., Costa, A., Brookes, P., Davidson, S., Duchen, M., Saeb-Parsy, K., Shattock, M., Robinson, A., Work, L., Frezza, C., Krieg, T. and Murphy, M. (2014). Ischaemic accumulation of succinate controls reperfusion injury through mitochondrial ROS. Nature, 515(7527), pp.431-435.

Chouchani, E., Pell, V., James, A., Work, L., Saeb-Parsy, K., Frezza, C., Krieg, T. and Murphy, M. (2016). A Unifying Mechanism for Mitochondrial Superoxide Production during Ischemia-Reperfusion Injury. Cell Metabolism, 23(2), pp.254-263.

Corps, K., Roth, T. and McGavern, D. (2015). Inflammation and Neuroprotection in Traumatic Brain Injury. JAMA Neurology, 72(3), p.355.

Culmsee, C. and Mattson, M. (2005). p53 in neuronal apoptosis. Biochemical and Biophysical Research Communications, 331(3), pp.761-777. 
D'Autréaux, B. and Toledano, M. (2007). ROS as signalling molecules: mechanisms that generate specificity in ROS homeostasis. Nature Reviews Molecular Cell Biology, 8(10), pp.813-824.

Deb, P., Sharma, S. and Hassan, K. (2010). Pathophysiologic mechanisms of acute ischemic stroke: An overview with emphasis on therapeutic significance beyond thrombolysis. Pathophysiology, 17(3), pp.197-218.

Delgado-Esteban, M., García-Higuera, I., Maestre, C., Moreno, S. and Almeida, A. (2013). APC/C-Cdh1 coordinates neurogenesis and cortical size during development. Nature Communications, 4(1).

Demyanenko, S. and Uzdensky, A. (2016). Profiling of Signaling Proteins in Penumbra After Focal Photothrombotic Infarct in the Rat Brain Cortex. Molecular Neurobiology, 54(9), pp.6839-6856.

Dennerlein, S. and Rehling, P. (2015). Human mitochondrial COX1 assembly into cytochrome c oxidase at a glance. Journal of Cell Science, 128(5), pp.833-837.

Donkor, E. (2018). Stroke in the 21st Century: A Snapshot of the Burden, Epidemiology, and Quality of Life. Stroke Research and Treatment, 2018, pp.1-10.

Donnan, G., Fisher, M., Macleod, M. and Davis, S. (2008). Stroke. The Lancet, 371(9624), pp.1612-1623.

Doyle, K., Simon, R. and Stenzel-Poore, M. (2008). Mechanisms of ischemic brain damage. Neuropharmacology, 55(3), pp.310-318.

Dringen, R., Pawlowski, P. and Hirrlinger, J. (2004). Peroxide detoxification by brain cells. Journal of Neuroscience Research, 79(1-2), pp.157-165.

Eltzschig, H. and Eckle, T. (2011). Ischemia and reperfusion-from mechanism to translation. Nature Medicine, 17(11), pp.1391-1401. 
Fernández, G., Moraga, A., Cuartero, M., García-Culebras, A., Peña-Martínez, C., Pradillo, J., Hernández-Jiménez, M., Sacristán, S., Ayuso, M., Gonzalo-Gobernado, R., Fernández-López, D., Martín, M., Moro, M., González, V. and Lizasoain, I. (2018). TLR4-Binding DNA Aptamers Show a Protective Effect against Acute Stroke in Animal Models. Molecular Therapy, 26(8), pp.2047-2059.

Firuzi, O., Miri, R., Tavakkoli, M. and Saso, L. (2011). Antioxidant Therapy: Current Status and Future Prospects. Current Medicinal Chemistry, 18(25), pp.3871-3888.

Furlan, M., Marchal, G., Derlon, J., Baron, J. and Viader, F. (1996). Spontaneous neurological recovery after stroke and the fate of the ischemic penumbra. Annals of Neurology, 40(2), pp.216-226.

Gomez-Sanchez, J., Delgado-Esteban, M., Rodriguez-Hernandez, I., Sobrino, T., Perez de la Ossa, N., Reverte, S., Bolaños, J., Gonzalez-Sarmiento, R., Castillo, J. and Almeida, A. (2011). The humanTp53 Arg72Propolymorphism explains different functional prognosis in stroke. The Journal of Experimental Medicine, 208(3), pp.429437.

Gorman, A. (2008). Neuronal cell death in neurodegenerative diseases: recurring themes around protein handling. Journal of Cellular and Molecular Medicine, 12(6a), pp.2263-2280.

Goyal, M., Menon, B., van Zwam, W., Dippel, D., Mitchell, P., Demchuk, A., Dávalos, A., Majoie, C., van der Lugt, A., de Miquel, M., Donnan, G., Roos, Y., Bonafe, A., Jahan, R., Diener, H., van den Berg, L., Levy, E., Berkhemer, O., Pereira, V., Rempel, J., Millán, M., Davis, S., Roy, D., Thornton, J., Román, L., Ribó, M., Beumer, D., Stouch, B., Brown, S., Campbell, B., van Oostenbrugge, R., Saver, J., Hill, M. and Jovin, T. (2016). Endovascular thrombectomy after large-vessel ischaemic stroke: a meta-analysis of individual patient data from five randomised trials. The Lancet, 387(10029), pp.1723-1731.

Granger, D. and Kvietys, P. (2015). Reperfusion injury and reactive oxygen species: The evolution of a concept. Redox Biology, 6, pp.524-551. 
Gravanis, I. and Tsirka, S. (2008). Tissue-type plasminogen activator as a therapeutic target in stroke. Expert Opinion on Therapeutic Targets, 12(2), pp.159-170.

Gray, S. and Jandeleit-Dahm, K. (2015). The role of NADPH Oxidase in Vascular Disease - Hypertension, Atherosclerosis \& Stroke. Current Pharmaceutical Design, 21(41), pp.5933-5944.

Green, D. (2004). The Pathophysiology of Mitochondrial Cell Death. Science, 305(5684), pp.626-629.

Green, D., Galluzzi, L. and Kroemer, G. (2011). Mitochondria and the AutophagyInflammation-Cell Death Axis in Organismal Aging. Science, 333(6046), pp.11091112.

Halliwell, B. (2011). Free radicals and antioxidants - quo vadis?. Trends in Pharmacological Sciences, 32(3), pp.125-130.

Halpain, S. and Dehmelt, L. (2006). The MAP1 family of microtubule-associated proteins. Genome Biology, 7(6), p.224.

Hekimi, S., Lapointe, J. and Wen, Y. (2011). Taking a "good" look at free radicals in the aging process. Trends in Cell Biology, 21(10), pp.569-576.

Herrero-Mendez, A., Almeida, A., Fernández, E., Maestre, C., Moncada, S. and Bolaños, J. (2009). The bioenergetic and antioxidant status of neurons is controlled by continuous degradation of a key glycolytic enzyme by APC/C-Cdh1. Nature Cell Biology, 11(6), pp.747-752.

Holmgren, A. and Lu, J. (2010). Thioredoxin and thioredoxin reductase: Current research with special reference to human disease. Biochemical and Biophysical Research Communications, 396(1), pp.120-124.

Holmström, K. and Finkel, T. (2014). Cellular mechanisms and physiological consequences of redox-dependent signalling. Nature Reviews Molecular Cell Biology, 15(6), pp.411-421. 
Huang, M., Sharma, S., Zhu, L., Keane, M., Luo, J., Zhang, L., Burdick, M., Lin, Y., Dohadwala, M., Gardner, B., Batra, R., Strieter, R. and Dubinett, S. (2002). IL-7 inhibits fibroblast TGF- $\beta$ production and signaling in pulmonary fibrosis. Journal of Clinical Investigation, 109(7), pp.931-937.

Huttner, H., Bergmann, O., Salehpour, M., Rácz, A., Tatarishvili, J., Lindgren, E., Csonka, T., Csiba, L., Hortobágyi, T., Méhes, G., Englund, E., Solnestam, B., Zdunek, S., Scharenberg, C., Ström, L., Ståhl, P., Sigurgeirsson, B., Dahl, A., Schwab, S., Possnert, G., Bernard, S., Kokaia, Z., Lindvall, O., Lundeberg, J. and Frisén, J. (2014). The age and genomic integrity of neurons after cortical stroke in humans. Nature Neuroscience, 17(6), pp.801-803.

Iadecola, C. and Anrather, J. (2011). The immunology of stroke: from mechanisms to translation. Nature Medicine, 17(7), pp.796-808.

Jimenez-Blasco, D., Santofimia-Castaño, P., Gonzalez, A., Almeida, A. and Bolaños, J. (2015). Astrocyte NMDA receptors' activity sustains neuronal survival through a Cdk5-Nrf2 pathway. Cell Death \& Differentiation, 22(11), pp.1877-1889.

Jimenez-Blasco, D., Santofimia-Castaño, P., Gonzalez, A., Almeida, A. and Bolaños, J. (2015). Astrocyte NMDA receptors' activity sustains neuronal survival through a Cdk5-Nrf2 pathway. Cell Death \& Differentiation, 22(11), pp.1877-1889.

Johnson, J., Johnson, D., Kraft, A., Calkins, M., Jakel, R., Vargas, M. and Chen, P. (2008). The Nrf2-ARE Pathway. Annals of the New York Academy of Sciences, 1147(1), pp.61-69.

Katsura, K., Kristián, T. and Siesjö, B. (1994). Energy metabolism, ion homeostasis, and cell damage in the brain. Biochemical Society Transactions, 22(4), pp.991-996.

Kew, J. and Kemp, J. (2005). Ionotropic and metabotropic glutamate receptor structure and pharmacology. Psychopharmacology, 179(1), pp.4-29.

Kho, A., Choi, B., Lee, S., Hong, D., Lee, S., Jeong, J., Park, K., Song, H., Choi, H. and Suh, S. (2018). Effects of Protocatechuic Acid (PCA) on Global Cerebral Ischemia- 
Induced Hippocampal Neuronal Death. International Journal of Molecular Sciences, 19(5), p.1420.

Khoshnam, S., Winlow, W., Farzaneh, M., Farbood, Y. and Moghaddam, H. (2017). Pathogenic mechanisms following ischemic stroke. Neurological Sciences, 38(7), pp.1167-1186.

Kim, G., Kim, J., Rhie, S. and Yoon, S. (2015). The Role of Oxidative Stress in Neurodegenerative Diseases. Experimental Neurobiology, 24(4), p.325.

Kleinschnitz, C., Grund, H., Wingler, K., Armitage, M., Jones, E., Mittal, M., Barit, D., Schwarz, T., Geis, C., Kraft, P., Barthel, K., Schuhmann, M., Herrmann, A., Meuth, S., Stoll, G., Meurer, S., Schrewe, A., Becker, L., Gailus-Durner, V., Fuchs, H., Klopstock, T., de Angelis, M., Jandeleit-Dahm, K., Shah, A., Weissmann, N. and Schmidt, H. (2010). Post-Stroke Inhibition of Induced NADPH Oxidase Type 4 Prevents Oxidative Stress and Neurodegeneration. PLoS Biology, 8(9), p.e1000479.

Koizumi, J., Yoshida, Y., Nakazawa, T. and Ooneda, G. (1986). Experimental studies of ischemic brain edema. Nosotchu, 8(1), pp.1-8.

Kowaltowski, A., de Souza-Pinto, N., Castilho, R. and Vercesi, A. (2009). Mitochondria and reactive oxygen species. Free Radical Biology and Medicine, 47(4), pp.333-343.

Lai, T., Zhang, S. and Wang, Y. (2014). Excitotoxicity and stroke: Identifying novel targets for neuroprotection. Progress in Neurobiology, 115, pp.157-188.

Lapresa, R., Agulla, J., Sánchez-Morán, I., Zamarreño, R., Prieto, E., Bolaños, J. and Almeida, A. (2019). Amyloid- $\beta$ promotes neurotoxicity by Cdk5-induced p53 stabilization. Neuropharmacology, 146, pp.19-27.

Lee, S., Choi, K., Ahn, H., Song, K., Choe, J. and Lee, I. (2005). TuJ1 (class III $\beta$ tubulin) expression suggests dynamic redistribution of follicular dendritic cells in lymphoid tissue. European Journal of Cell Biology, 84(2-3), pp.453-459. 
Lei, X., Zhu, J., Cheng, W., Bao, Y., Ho, Y., Reddi, A., Holmgren, A. and Arnér, E. (2016). Paradoxical Roles of Antioxidant Enzymes: Basic Mechanisms and Health Implications. Physiological Reviews, 96(1), pp.307-364.

Liguori, I., Russo, G., Curcio, F., Bulli, G., Aran, L., Della-Morte, D., Gargiulo, G., Testa, G., Cacciatore, F., Bonaduce, D. and Abete, P. (2018). Oxidative stress, aging, and diseases. Clinical Interventions in Aging, Volume 13, pp.757-772.

Liu, K., Ding, L., Li, Y., Yang, H., Zhao, C., Lei, Y., Han, S., Tao, W., Miao, D., Steller, H., Welsh, M. and Liu, L. (2014). Neuronal necrosis is regulated by a conserved chromatin-modifying cascade. Proceedings of the National Academy of Sciences, 111(38), pp.13960-13965.

Liu, R., Yuan, H., Yuan, F. and Yang, S. (2012). Neuroprotection targeting ischemic penumbra and beyond for the treatment of ischemic stroke. Neurological Research, 34(4), pp.331-337.

Longa, E., Weinstein, P., Carlson, S. and Cummins, R. (1989). Reversible middle cerebral artery occlusion without craniectomy in rats. Stroke, 20(1), pp.84-91.

Lopez-Fabuel, I., Le Douce, J., Logan, A., James, A., Bonvento, G., Murphy, M., Almeida, A. and Bolaños, J. (2016). Complex I assembly into supercomplexes determines differential mitochondrial ROS production in neurons and astrocytes. Proceedings of the National Academy of Sciences, 113(46), pp.13063-13068.

Lossi, L. and Merighi, A. (2003). In vivo cellular and molecular mechanisms of neuronal apoptosis in the mammalian CNS. Progress in Neurobiology, 69(5), pp.287312.

Maejima, Y., Kuroda, J., Matsushima, S., Ago, T. and Sadoshima, J. (2011). Regulation of myocardial growth and death by NADPH oxidase. Journal of Molecular and Cellular Cardiology, 50(3), pp.408-416. 
Maestre, C., Delgado-Esteban, M., Gomez-Sanchez, J., Bolaños, J. and Almeida, A. (2008). Cdk5 phosphorylates Cdh1 and modulates cyclin B1 stability in excitotoxicity. The EMBO Journal, 27(20), pp.2736-2745.

Maestre, C., Delgado-Esteban, M., Gomez-Sanchez, J., Bolaños, J. and Almeida, A. (2008). Cdk5 phosphorylates Cdh1 and modulates cyclin B1 stability in excitotoxicity. The EMBO Journal, 27(20), pp.2736-2745.

Mahdi-Pour, B., Jothy, S., Latha, L., Chen, Y. and Sasidharan, S. (2012). Antioxidant activity of methanol extracts of different parts of Lantana camara. Asian Pacific Journal of Tropical Biomedicine, 2(12), pp.960-965.

Mallucci, G., Peruzzotti-Jametti, L., Bernstock, J. and Pluchino, S. (2015). The role of immune cells, glia and neurons in white and gray matter pathology in multiple sclerosis. Progress in Neurobiology, 127-128, pp.1-22.

Margaill, I., Plotkine, M. and Lerouet, D. (2005). Antioxidant strategies in the treatment of stroke. Free Radical Biology and Medicine, 39(4), pp.429-443.

Marí, M., Morales, A., Colell, A., García-Ruiz, C. and Fernández-Checa, J. (2009). Mitochondrial Glutathione, a Key Survival Antioxidant. Antioxidants \& Redox Signaling, 11(11), pp.2685-2700.

Masjuan, J., Álvarez-Sabín, J., Arenillas, J., Calleja, S., Castillo, J., Dávalos, A., Tejedor, E., Freijo, M., Gil-Núñez, A., Fernández, J., Maestre, J., Martínez-Vila, E., Morales, A., Purroy, F., Ramírez, J., Segura, T., Serena, J., Tejada, J. and Tejero, C. (2011). Plan de asistencia sanitaria al ICTUS II. 2010. Neurología, 26(7), pp.383-396.

Mehta, S., Manhas, N. and Raghubir, R. (2007). Molecular targets in cerebral ischemia for developing novel therapeutics. Brain Research Reviews, 54(1), pp.34-66.

Miao, L. and St. Clair, D. (2009). Regulation of superoxide dismutase genes: Implications in disease. Free Radical Biology and Medicine, 47(4), pp.344-356. 
Michaelis, L. (1998). Journal search results - Cite This For Me. Mitigation and Adaptation Strategies for Global Change, 3(2/4), pp.231-261.

Monaghan, D., Bridges, R. and Cotman, C. (1989). The Excitatory Amino Acid Receptors: Their Classes, Pharmacology, and Distinct Properties in the Function of the Central Nervous System. Annual Review of Pharmacology and Toxicology, 29(1), pp.365-402.

Montaner, J., Alvarez-Sabín, J., Molina, C., Anglés, A., Abilleira, S., Arenillas, J., González, M. and Monasterio, J. (2001). Matrix Metalloproteinase Expression After Human Cardioembolic Stroke. Stroke, 32(8), pp.1759-1766.

Moraga, A., Pradillo, J., Cuartero, M., Hernández-Jiménez, M., Oses, M., Moro, M. and Lizasoain, I. (2014). Toll-like receptor 4 modulates cell migration and cortical neurogenesis after focal cerebral ischemia. The FASEB Journal, 28(11), pp.4710-4718.

MORO, M., ALMEIDA, A., BOLANOS, J. and LIZASOAIN, I. (2005). Mitochondrial respiratory chain and free radical generation in stroke. Free Radical Biology and Medicine, 39(10), pp.1291-1304.

Moro, M., Cárdenas, A., Hurtado, O., Leza, J. and Lizasoain, I. (2004). Role of nitric oxide after brain ischaemia. Cell Calcium, 36(3-4), pp.265-275.

Morris, M., Beckett, L., Scherr, P., Hebert, L., Bennett, D., Field, T. and Evans, D. (1998). Vitamin E and Vitamin C Supplement Use and Risk of Incident Alzheimer Disease. Alzheimer Disease \& Associated Disorders, 12(3), pp.121-126.

Mozaffarian, D., Benjamin, E., Go, A., Arnett, D., Blaha, M., Cushman, M., Das, S., de Ferranti, S., Després, J., Fullerton, H., Howard, V., Huffman, M., Isasi, C., Jiménez, M., Judd, S., Kissela, B., Lichtman, J., Lisabeth, L., Liu, S., Mackey, R., Magid, D., McGuire, D., Mohler, E., Moy, C., Muntner, P., Mussolino, M., Nasir, K., Neumar, R., Nichol, G., Palaniappan, L., Pandey, D., Reeves, M., Rodriguez, C., Rosamond, W., Sorlie, P., Stein, J., Towfighi, A., Turan, T., Virani, S., Woo, D., Yeh, R. and Turner, M. (2016). Heart Disease and Stroke Statistics_-2016 Update. Circulation, 133(4). 
Mukhopadhyay, P., Rajesh, M., Haskó, G., Hawkins, B., Madesh, M. and Pacher, P. (2007). Simultaneous detection of apoptosis and mitochondrial superoxide production in live cells by flow cytometry and confocal microscopy. Nature Protocols, 2(9), pp.2295-2301.

Murphy, M. (2009). How mitochondria produce reactive oxygen species. Biochemical Journal, 417(1), pp.1-13.

Murphy, M. (2014). Antioxidants as therapies: can we improve on nature?. Free Radical Biology and Medicine, 66, pp.20-23.

Nagy, Z. and Nardai, S. (2017). Cerebral ischemia/repefusion injury: From bench space to bedside. Brain Research Bulletin, 134, pp.30-37.

Nakamura, K. and Shichita, T. (2019). Cellular and molecular mechanisms of sterile inflammation in ischaemic stroke. The Journal of Biochemistry.

Nasr, I., Chun, Y. and Kannan, S. (2019). Neuroimmune responses in the developing brain following traumatic brain injury. Experimental Neurology, p.112957.

Nathan, C. and Cunningham-Bussel, A. (2013). Beyond oxidative stress: an immunologist's guide to reactive oxygen species. Nature Reviews Immunology, 13(5), pp.349-361.

Nedergaard, M. and Dirnagl, U. (2005). Role of glial cells in cerebral ischemia. Glia, 50(4), pp.281-286.

Niki, E. (2009). Lipid peroxidation: Physiological levels and dual biological effects. Free Radical Biology and Medicine, 47(5), pp.469-484.

Okabe, N., Himi, N., Maruyama-Nakamura, E., Hayashi, N., Narita, K. and Miyamoto, O. (2017). Rehabilitative skilled forelimb training enhances axonal remodeling in the corticospinal pathway but not the brainstem-spinal pathways after photothrombotic stroke in the primary motor cortex. PLOS ONE, 12(11), p.e0187413. 
OLNEY, J. (1971). GLUTAMATE-INDUCED NEURONAL NECROSIS IN THE INFANT MOUSE HYPOTHALAMUS. Journal of Neuropathology and Experimental Neurology, 30(1), pp.75-90.

Orrenius, S., Zhivotovsky, B. and Nicotera, P. (2003). Regulation of cell death: the calcium-apoptosis link. Nature Reviews Molecular Cell Biology, 4(7), pp.552-565.

Oswald, M., Brooks, P., Zwart, M., Mukherjee, A., West, R., Giachello, C., Morarach, K., Baines, R., Sweeney, S. and Landgraf, M. (2018). Reactive oxygen species regulate activity-dependent neuronal plasticity in Drosophila. eLife, 7.

Ozawa, S. (1998). Glutamate receptors in the mammalian central nervous system. Progress in Neurobiology, 54(5), pp.581-618.

Pan, J., Konstas, A., Bateman, B., Ortolano, G. and Pile-Spellman, J. (2006). Reperfusion injury following cerebral ischemia: pathophysiology, MR imaging, and potential therapies. Neuroradiology, 49(2), pp.93-102.

Parathath, S., Gravanis, I. and Tsirka, S. (2007). Nitric Oxide Synthase Isoforms Undertake Unique Roles During Excitotoxicity. Stroke, 38(6), pp.1938-1945.

Pellegrini-Giampietro, D. (2003). The distinct role of mGlu1 receptors in post-ischemic neuronal death. Trends in Pharmacological Sciences, 24(9), pp.461-470.

Peter, M. (2011). Apoptosis meets necrosis. Nature, 471(7338), pp.310-312.

Powers, S., Ji, L., Kavazis, A. and Jackson, M. (2011). Reactive Oxygen Species: Impact on Skeletal Muscle. Comprehensive Physiology.

Poyton, R., Ball, K. and Castello, P. (2009). Mitochondrial generation of free radicals and hypoxic signaling. Trends in Endocrinology \& Metabolism, 20(7), pp.332-340.

Quintana-Cabrera, R., Fernandez-Fernandez, S., Bobo-Jimenez, V., Escobar, J., Sastre, J., Almeida, A. and Bolaños, J. (2012). $\gamma$-Glutamylcysteine detoxifies reactive oxygen species by acting as glutathione peroxidase-1 cofactor. Nature Communications, 3(1). 
Raingeaud, J., Gupta, S., Rogers, J., Dickens, M., Han, J., Ulevitch, R. and Davis, R. (1995). Pro-inflammatory Cytokines and Environmental Stress Cause p38 Mitogenactivated Protein Kinase Activation by Dual Phosphorylation on Tyrosine and Threonine. Journal of Biological Chemistry, 270(13), pp.7420-7426.

Ramee, S., Subramanian, R., Felberg, R., McKinley, K., Jenkins, J., Collins, T., Dawson, R. and White, C. (2004). Catheter-Based Treatment for Patients With Acute Ischemic Stroke Ineligible for Intravenous Thrombolysis. Stroke, 35(5).

Rami, A. and Kögel, D. (2008). Apoptosis meets autophagy-like cell death in the ischemic penumbra: Two sides of the same coin?. Autophagy, 4(4), pp.422-426.

Ramos-Cabrer, P., Campos, F., Sobrino, T. and Castillo, J. (2010). Targeting the Ischemic Penumbra. Stroke, 42(1, Supplement 1), pp.S7-S11.

Ramos-Cabrer, P., Campos, F., Sobrino, T. and Castillo, J. (2010). Targeting the Ischemic Penumbra. Stroke, 42(1, Supplement 1), pp.S7-S11.

Reczek, C. and Chandel, N. (2015). ROS-dependent signal transduction. Current Opinion in Cell Biology, 33, pp.8-13.

Rhee, S., Woo, H. and Kang, D. (2018). The Role of Peroxiredoxins in the Transduction of H2O2 Signals. Antioxidants \& Redox Signaling, 28(7), pp.537-557.

Richter, K., Langnaese, K., Kreutz, M., Olias, G., Zhai, R., Scheich, H., Garner, C. and Gundelfinger, E. (1999). Presynaptic cytomatrix protein Bassoon is localized at both excitatory and inhibitory synapses of rat brain. The Journal of Comparative Neurology, 408(3), pp.437-448.

Rodrigo, R., Fernandez-Gajardo, R., Gutierrez, R., Matamala, J., Carrasco, R., Miranda-Merchak, A. and Feuerhake, W. (2013). Oxidative Stress and Pathophysiology of Ischemic Stroke: Novel Therapeutic Opportunities. CNS \& Neurological Disorders - Drug Targets, 12(5), pp.698-714. 
Rodríguez, C., Ramos-Araque, M., Domínguez-Martínez, M., Sobrino, T., SánchezMorán, I., Agulla, J., Delgado-Esteban, M., Gómez-Sánchez, J., Bolaños, J., Castillo, J. and Almeida, A. (2018). Single-Nucleotide Polymorphism $\quad 309 T>G \quad$ in the MDM2 Promoter Determines Functional Outcome After Stroke. Stroke, 49(10), pp.2437-2444.

Rodríguez, C., Sobrino, T., Agulla, J., Bobo-Jiménez, V., Ramos-Araque, M., Duarte, J., Gómez-Sánchez, J., Bolaños, J., Castillo, J. and Almeida, Á. (2016). Neovascularization and functional recovery after intracerebral hemorrhage is conditioned by the Tp53 Arg72Pro single-nucleotide polymorphism. Cell Death \& Differentiation, 24(1), pp.144-154.

Rodriguez-Rodriguez, P., Almeida, A. and Bolaños, J. (2013). Brain energy metabolism in glutamate-receptor activation and excitotoxicity: Role for APC/C-Cdh1 in the balance glycolysis/pentose phosphate pathway. Neurochemistry International, 62(5), pp.750-756.

Rothman, S. and Olney, J. (1986). Glutamate and the pathophysiology of hypoxicischemic brain damage. Annals of Neurology, 19(2), pp.105-111.

Saenger, A. and Christenson, R. (2009). Stroke Biomarkers: Progress and Challenges for Diagnosis, Prognosis, Differentiation, and Treatment. Clinical Chemistry, 56(1), pp.21-33.

Sairanen, T., Szepesi, R., Karjalainen-Lindsberg, M., Saksi, J., Paetau, A. and Lindsberg, P. (2009). Neuronal caspase-3 and PARP-1 correlate differentially with apoptosis and necrosis in ischemic human stroke. Acta Neuropathologica, 118(4), pp.541-552.

Salim, S. (2016). Oxidative Stress and the Central Nervous System. Journal of Pharmacology and Experimental Therapeutics, 360(1), pp.201-205.

Salvesen, G. and Dixit, V. (1999). Caspase activation: The induced-proximity model. Proceedings of the National Academy of Sciences, 96(20), pp.10964-10967. 
Saso, L. and Firuzi, O. (2014). Pharmacological Applications of Antioxidants: Lights and Shadows. Current Drug Targets, 15(13), pp.1177-1199.

Sattler, T. and Mayer, A. (2000). Cell-Free Reconstitution of Microautophagic Vacuole Invagination and Vesicle Formation. The Journal of Cell Biology, 151(3), pp.529-538.

Sax, J., Fei, P., Murphy, M., Bernhard, E., Korsmeyer, S. and El-Deiry, W. (2002). BID regulation by p53 contributes to chemosensitivity. Nature Cell Biology, 4(11), pp.842849.

Scialò, F., Fernández-Ayala, D. and Sanz, A. (2017). Role of Mitochondrial Reverse Electron Transport in ROS Signaling: Potential Roles in Health and Disease. Frontiers in Physiology, 8.

Sheng, M. and Kim, E. (2011). The Postsynaptic Organization of Synapses. Cold Spring Harbor Perspectives in Biology, 3(12), pp.a005678-a005678.

Sheu, J. (2018). Molecular Pharmacology and Pathology of Strokes. International Journal of Molecular Sciences, 19(12), p.4103.

Shih, A. (2005). A Small-Molecule-Inducible Nrf2-Mediated Antioxidant Response Provides Effective Prophylaxis against Cerebral Ischemia In Vivo. Journal of Neuroscience, 25(44), pp.10321-10335.

Shirley, R., Ord, E. and Work, L. (2014). Oxidative Stress and the Use of Antioxidants in Stroke. Antioxidants, 3(3), pp.472-501.

Singh, A., Kukreti, R., Saso, L. and Kukreti, S. (2019). Oxidative Stress: A Key Modulator in Neurodegenerative Diseases. Molecules, 24(8), p.1583.

Siniscalchi, A., Gallelli, L., Malferrari, G., Pirritano, D., Serra, R., Santangelo, E. and De Sarro, G. (2014). Cerebral stroke injury: the role of cytokines and brain inflammation. Journal of Basic and Clinical Physiology and Pharmacology, 25(2). 
Smith, W., Sung, G., Saver, J., Budzik, R., Duckwiler, G., Liebeskind, D., Lutsep, H., Rymer, M., Higashida, R., Starkman, S. and Gobin, Y. (2008). Mechanical Thrombectomy for Acute Ischemic Stroke. Stroke, 39(4), pp.1205-1212.

Song, M. and Yu, S. (2013). Ionic Regulation of Cell Volume Changes and Cell Death after Ischemic Stroke. Translational Stroke Research, 5(1), pp.17-27.

Sutherland, B., Minnerup, J., Balami, J., Arba, F., Buchan, A. and Kleinschnitz, C. (2012). Neuroprotection for Ischaemic Stroke: Translation from the Bench to the Bedside. International Journal of Stroke, 7(5), pp.407-418.

Taylor, R., Cullen, S. and Martin, S. (2008). Apoptosis: controlled demolition at the cellular level. Nature Reviews Molecular Cell Biology, 9(3), pp.231-241.

Temple, M., Perrone, G. and Dawes, I. (2005). Complex cellular responses to reactive oxygen species. Trends in Cell Biology, 15(6), pp.319-326.

Thannickal, V. and Fanburg, B. (2000). Reactive oxygen species in cell signaling. American Journal of Physiology-Lung Cellular and Molecular Physiology, 279(6), pp.L1005-L1028.

Timmer, J. and Salvesen, G. (2006). Caspase substrates. Cell Death \& Differentiation, 14(1), pp.66-72.

Tissue Plasminogen Activator for Acute Ischemic Stroke. (1995). New England Journal of Medicine, 333(24), pp.1581-1588.

Toshiyuki, M. and Reed, J. (1995). Tumor suppressor p53 is a direct transcriptional activator of the human bax gene. Cell, 80(2), pp.293-299.

Tyler, D. (1975). Polarographic assay and intracellular distribution of superoxide dismutase in rat liver. Biochemical Journal, 147(3), pp.493-504. 
van der Worp, H., Sena, E., Donnan, G., Howells, D. and Macleod, M. (2007). Hypothermia in animal models of acute ischaemic stroke: a systematic review and meta-analysis. Brain, 130(12), pp.3063-3074.

Veas-Perez de Tudela, M., Delgado-Esteban, M., Maestre, C., Bobo-Jimenez, V., Jimenez-Blasco, D., Vecino, R., Bolanos, J. and Almeida, A. (2015). Regulation of BclxL-ATP Synthase Interaction by Mitochondrial Cyclin B1-Cyclin-Dependent Kinase1 Determines Neuronal Survival. Journal of Neuroscience, 35(25), pp.9287-9301.

Veas-Perez de Tudela, M., Delgado-Esteban, M., Maestre, C., Bobo-Jimenez, V., Jimenez-Blasco, D., Vecino, R., Bolanos, J. and Almeida, A. (2015). Regulation of BclxL-ATP Synthase Interaction by Mitochondrial Cyclin B1-Cyclin-Dependent Kinase1 Determines Neuronal Survival. Journal of Neuroscience, 35(25), pp.9287-9301.

Veas-Perez de Tudela, M., Delgado-Esteban, M., Maestre, C., Bobo-Jimenez, V., Jimenez-Blasco, D., Vecino, R., Bolanos, J. and Almeida, A. (2015). Regulation of BclxL-ATP Synthase Interaction by Mitochondrial Cyclin B1-Cyclin-Dependent Kinase1 Determines Neuronal Survival. Journal of Neuroscience, 35(25), pp.9287-9301.

Veas-Pérez de Tudela, M., Maestre, C., Delgado-Esteban, M., Bolaños, J. and Almeida, A. (2015). Cdk5-mediated inhibition of APC/C-Cdh1 switches on the cyclin D1-Cdk4$\mathrm{pRb}$ pathway causing aberrant S-phase entry of postmitotic neurons. Scientific Reports, $5(1)$.

Veas-Pérez de Tudela, M., Maestre, C., Delgado-Esteban, M., Bolaños, J. and Almeida, A. (2015). Cdk5-mediated inhibition of APC/C-Cdh1 switches on the cyclin D1-Cdk4pRb pathway causing aberrant S-phase entry of postmitotic neurons. Scientific Reports, $5(1)$.

Venkataraman, K., Khurana, S. and Tai, T. (2013). Oxidative Stress in Aging-Matters of the Heart and Mind. International Journal of Molecular Sciences, 14(9), pp.1789717925.

Vicente-Gutierrez, C., Bonora, N., Bobo-Jimenez, V., Jimenez-Blasco, D., LopezFabuel, I., Fernandez, E., Josephine, C., Bonvento, G., Enriquez, J., Almeida, A. and 
Bolaños, J. (2019). Astrocytic mitochondrial ROS modulate brain metabolism and mouse behaviour. Nature Metabolism, 1(2), pp.201-211.

Wiedenmann, B. and Franke, W. (1985). Identification and localization of synaptophysin, an integral membrane glycoprotein of $\mathrm{Mr} 38,000$ characteristic of presynaptic vesicles. Cell, 41(3), pp.1017-1028.

Wiendl, H. (2015). Myositiden: Pathogenese und Therapie. Drug Research, 65(S 01), pp.S20-S20.

Wu, Y., Li, W., Xu, Y., Jin, E. and Tu, Y. (2011). Evaluation of the antioxidant effects of four main theaflavin derivatives through chemiluminescence and DNA damage analyses. Journal of Zhejiang University SCIENCE B, 12(9), pp.744-751.

Yan, L. (2014). Protein Redox Modification as a Cellular Defense Mechanism against Tissue Ischemic Injury. Oxidative Medicine and Cellular Longevity, 2014, pp.1-12.

Young, D., Pedre, B., Ezeriņa, D., De Smet, B., Lewandowska, A., Tossounian, M., Bodra, N., Huang, J., Astolfi Rosado, L., Van Breusegem, F. and Messens, J. (2019). Protein Promiscuity in H2O2 Signaling. Antioxidants \& Redox Signaling, 30(10), pp.1285-1324.

Yuan, J., Lipinski, M. and Degterev, A. (2003). Diversity in the Mechanisms of Neuronal Cell Death. Neuron, 40(2), pp.401-413.

Zámocký, M. and Koller, F. (1999). Understanding the structure and function of catalases: clues from molecular evolution and in vitro mutagenesis. Progress in Biophysics and Molecular Biology, 72(1), pp.19-66.

Zamocky, M., Furtmüller, P. and Obinger, C. (2008). Evolution of Catalases from Bacteria to Humans. Antioxidants \& Redox Signaling, 10(9), pp.1527-1548.

Zámocký, M., Furtmüller, P. and Obinger, C. (2010). Evolution of structure and function of Class I peroxidases. Archives of Biochemistry and Biophysics, 500(1), pp.45-57. 
Zheng, S., Gray, E., Chawla, G., Porse, B., O'Dell, T. and Black, D. (2012). PSD-95 is post-transcriptionally repressed during early neural development by PTBP1 and PTBP2. Nature Neuroscience, 15(3), pp.381-388.

Zou, S., Zhang, M., Feng, L., Zhou, Y., Li, L. and Ban, L. (2017). Protective effects of notoginsenoside R1 on cerebral ischemia-reperfusion injury in rats. Experimental and Therapeutic Medicine. 